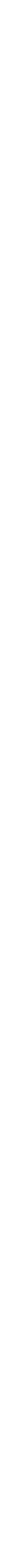




\title{
CUENTOS INFANTILES COMO ARMA COEDUCATIVA
}

\author{
Ana Isabel Quesada Chamorro
}

\author{
Directora \\ Victoria Robles Sanjuán \\ Universidad de Granada
}

Director de Apoyo

Marek Wojtaszek

Lodz University

Faculty of International and Political Studies

Universidad de Granada. Septiembre 2012 


\title{
CUENTOS INFANTILES COMO ARMA COEDUCATIVA
}

\author{
Ana Isabel Quesada Chamorro
}

\author{
Directora \\ Victoria Robles Sanjuán \\ Universidad de Granada \\ Director de Apoyo \\ Marek Wojtaszek \\ Lodz University
}

Faculty of International and Political Studies

Universidad de Granada. Septiembre 2012

Firma de aprobación: 


\section{RESUMEN}

Voy a estudiar la coeducación como propuesta pedagógica para visibilizar y denunciar los aspectos sexistas, desiguales y discriminatorios que aún se encuentran en el sistema educativo español. Para ello voy a centrarme en la literatura infantil, más concretamente en los cuentos infantiles, y comprobar si los valores que éstos transmiten sirven para crear modelos de comportamiento y de vida en niños y niñas de entre 0 y 6 años de edad, tomándolos como modelos verdaderos y acordes con la realidad.

El objetivo que me planteo es demostrar la importancia de utilizar la coeducación como propuesta pedagógica dentro del sistema educativo, para hacer visible cualquier componente sexista en el currículo escolar y evitar su reproducción a través de materiales didácticos como son los cuentos infantiles. Para ello voy a hacer una revisión de imágenes y contenidos en seis cuentos infantiles y mostrar los valores que éstos utilizan para el proceso educativo del niño y de la niña, y la construcción de las relaciones de género entre hombres y mujeres.

Quiero demostrar que existe una nueva generación de literatura infantil no sexista o coeducativa, que se fundamente en valores coeducativos tales como, igualdad, tolerancia, respeto, autonomía, paz, etcétera y se mantengan al margen de aquellos valores sexistas que imperan en algunos clásicos infantiles.

Me voy a centrar en esta etapa infantil, entre 0 y 6 años de edad porque considero que la literatura infantil es una herramienta muy útil de enseñanza a la vez que contraproducente, ya que genera construcciones sociales no identificadas y alejadas de los modelos de género de esta sociedad. 


\section{ABSTRACT}

I am going to investigate the coeducation as a pedagogical approach to visualize and report the sexist, unequal and discriminatory values that are still in the Spanish educational system. For this I want to focus on children's literature, specifically in children's stories, to see how the values that they transmit serve as model behavior and life for children between 0 and 6 years old, taking them as true models and in line with the reality

The aim, that I consider, is to demonstrate the importance of use the coeducation as a pedagogical approach within education system in order to make visible any sexist component in the school curriculum and prevent their reproduction through materials such as children's stories. For this, I want to make a visual and content revision in six children's tales and how these tales influence in the educational process of children and the construction of gender relations between women and men.

I want to demonstrate if there is a new generation of non-sexist children's literature or coeducational that is based on coeducational values such as equality, tolerance, respect, independence, peace, etcetera, and stay away from those sexist values that prevail in some children's classics.

I want to focus in this age period because I consider that children's literature is a useful tool for teaching and at the same time, I think it is a counterproductive tool because it generates unidentified social constructions of gender models in the society. 


\section{AGRADECIMIENTOS}

A todas aquellas personan que han formado parte en la elaboración y presentación de este texto, por su apoyo incondicional y su confianza puesta en mí, como persona, amiga, compañera y alumna, por todas aquellas mujeres que han formado parte de mi vida y me han hecho ser quien soy, pensar como pienso y actuar como actúo, porque estoy aquí gracias a ellas y porque me han acompañado a lo largo de mi trayectoria personal y profesional soportándome en mis peores momentos y acompañándome en los mejores.

A mis mejores amigos $y$ amigas por ser honestos/as, sinceros/as, comprensivos/as y críticos/as con mi situación y siempre darme ánimos y a mi familia, por acompañarme en todos y cada uno de los acontecimientos vividos a lo largo de este proceso, apoyándome y confiando en mis expectativas y objetivos propuestos.

Al profesor Juan Mata Anaya, por compartir sus conocimientos sobre literatura infantil y acercarme al universo de los cuentos infantiles.

Y en especial a mi tutora, Victoria Robles Sanjuán, porque sin ella no hubiese sido posible terminar este proceso de investigación, en el que he aprendido, cuestionado, llorado, reído, criticado, deconstruido y construido, y por hacerme releer y repensar cada palabra y párrafo escrito, porque ha sido mi guía para comenzar y culminar este trayecto.

Que estas líneas os hagan pensar, disfrutar y aprender, casi tanto como me lo han hecho a mí y espero abrir una puerta a otro modo de entender la educación, otro modo de entender la vida. 


\section{INDICE}

\section{2.- LA COEDUCACIÓN EN EDUCACIÓN INFANTIL Y EN EL} CURRÍCULUM

\section{1.- LEGISLACIÓN Y COEDUCACIÓN: UNA RELACIÓN}

COMPLEJA

\section{2.- EL CURRÍCULUM EN LA FORMACIÓN DEL PROFESORADO:}

2.2.1.- El compromiso coeducativo en la formación del profesorado en las universidades españolas.

2.2.2.- Lenguaje sexista como mecanismo de discriminación visible.

\section{3.- LA COEDUCACIÓN A DEBATE: DISCURSOS SOBRE UN CAMBIO}

2.3.2.- Proceso de socialización de niños y niñas y construcción social de la identidad masculina y femenina en la infancia.

2.3.3.- Relevancia de la literatura infantil en el proceso de socialización de niños y niñas

2.3.3.1.- Literatura clásica infantil como mecanismo de reproducción de modelos sexistas 88

2.3.4.- Aspectos coeducativos a revisar en los cuentos infantiles. .98 
3.- LA LITERATURA INFANTIL NO SEXISTA: METODOLOGÍAS PARA SU ANÁLISIS

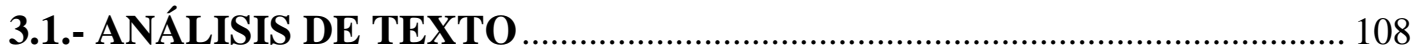

3.1.1- análisis de la estructura narrativa .............................108

3.1.2.- análisis lingüístico...............................................109

3.1.3.- análisis de discurso .............................................110

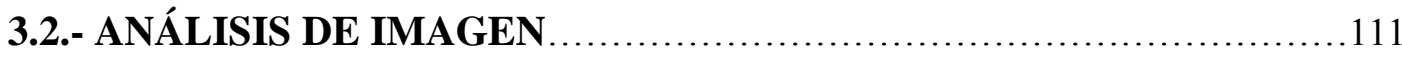

4.- LOS CUENTOS INFANTILES A ANÁLISIS ...............................113

4.1.- ¿HAY ALGO MÁS ABURRIDO QUE SER UNA PRINCESA

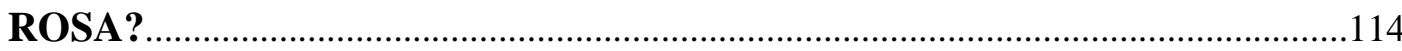

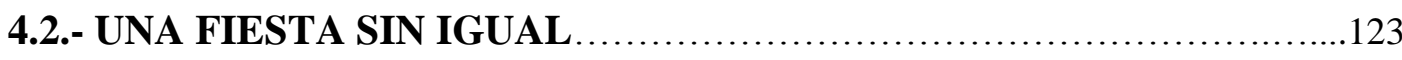

4.3.- LAS TRES MELLIZAS HACEN LAS PACES ............................131

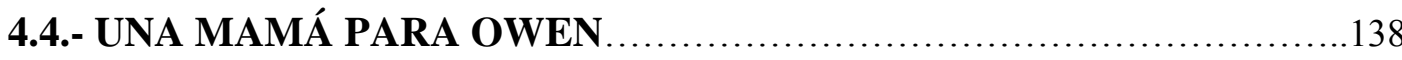

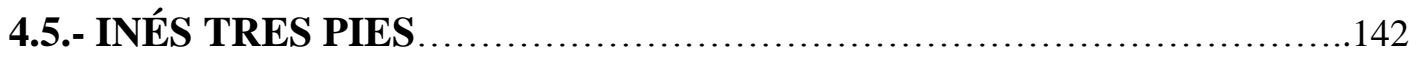

4.6.- ¡QUÉ GUAPA ERES, PLU!.......................................................................147

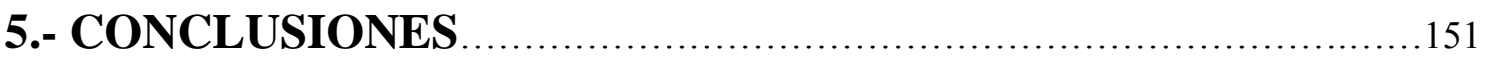

5.1.- PROPUESTAS PARA UNA FUTURA INVESTIGACIÓN..................156

6.- ANEXOS

7.- REFERENCIAS Y FUENTES BIBLIOGRÁFICAS 164 


\section{1.- INTRODUCCIÓN.}

La Coeducación, como intervención escolar para producir y conseguir cambios hacia una igualdad real entre hombres y mujeres tiene a día de hoy una historia muy reciente que está ligada a la evolución que ha sufrido la sociedad a través del concepto de igualdad en el que se asienta. Este concepto de igualdad ha ido cambiando con el tiempo y ampliándose a nuevos sujetos, de manera que las diferencias entre hombres y mujeres cuentan con una larga tradición basada en prejuicios acerca de la inferioridad de las mujeres tanto biológica como intelectual y moral. ${ }^{1}$

La demanda de proyectos coeducativos en los centros escolares ha sido una constante en el último tercio del siglo $\mathrm{XX}$, intentando eliminar estereotipos sexistas $\mathrm{y}$ discriminación en función del sexo, para conseguir una igualdad real entre hombres y mujeres. ${ }^{2}$ Las investigaciones y publicaciones de los últimos años muestran que el espacio escolar ha cambiado poco, se siguen detectando indicios de sexismo en los contenidos transmitidos en la escuela, bien a través de mensajes explícitos o implícitos, bien manteniendo comportamientos desiguales o generando actitudes que impiden que niñas y niños se formen, crezcan y se desarrollen en la escuela disfrutando de las mismas oportunidades. ${ }^{3}$ A la hora de analizar el material de apoyo en las escuelas, es evidente ver como el sexismo explícito va desapareciendo aunque todavía quedan reminiscencias. Sin embargo, todas las investigaciones recientes coindicen al afirmar

\footnotetext{
${ }^{1}$ Ballarín, Pilar. "Historia de la coeducación". En Tomé Amparo et al. Guía de buenas prácticas para favorecer la igualdad entre hombres y mujeres en educación. 2005, pp. 8

${ }^{2}$ Ibídem, 9

${ }^{3}$ España. Instituto de la mujer. Estudio para conocer la situación actual de la educación para la igualdad en España, 2004, pp. 6 
que se sigue manteniendo un especial freno discriminatorio en lo que tiene que ver con el "currículum oculto" ${ }^{\text {que se transmite al alumnado. }}{ }^{5}$

Es cierto que la educación escolar no es a día de hoy la solución a todos los problemas emergentes, pero sí es el espacio privilegiado para la construcción de una nueva ciudadanía con una perspectiva de género mediante propuestas educativas como es la coeducación. Coeducar es reconocer esa diversidad de experiencias, es buscar nuevas vías de intervención educativa para desarrollar relaciones de género más igualitarias y corregir y eliminar estereotipos sexistas, ${ }^{6}$ por ello la importancia de trabajar con niños y niñas desde edades muy tempranas bajo una línea coeducativa y partiendo de la literatura infantil, más concretamente desde los cuentos infantiles, siendo éstos la herramienta más útil para mostrar aspectos coeducativos en el aprendizaje del alumnado.

A través de este trabajo defiendo la importancia de educar bajo un planteamiento coeducativo tanto dentro como fuera de las instituciones educativas, apoyándome en la etapa de infantil y tomando el cuento infantil como herramienta, ya que constituye el instrumento principal de enseñanza empleado por las instituciones educativas y es la mejor herramienta pedagógica para transmitir valores coeducativos.

Para conseguir lo que me propongo es necesario revisar todo el planteamiento coeducativo en los diferentes niveles tanto legal, como político, curricular y literario y así establecer unas líneas generales sobre qué es coeducación y si nuestro sistema educativo cumple los objetivos que ésta incluye. También es importante revisar cómo se

\footnotetext{
${ }^{4}$ Con ello me refiero a aquellas prácticas visibles o no visibles que se continúan reproduciendo dentro del sistema educativo y se conforman de contenido sexista y desigual

${ }^{5}$ Ibídem, 199

"Ballarín, Pilar. "Historia de la coeducación". En Tomé, Amparo et al. Guía de buenas prácticas para favorecer la igualdad entre hombres y mujeres en educación, 2005, pp. 15-16
} 
articulan las instituciones educativas para comprobar qué conductas sexistas continúan reproduciéndose dentro del currículo oculto, así como indagar y estudiar donde se reproduce y perpetúa el sexismo.

Para indagar en el sexismo que aún continúa reproduciéndose, es necesario ver sus claves de desarrollo y su incidencia en la infancia; para ello considero imprescindible hacer una revisión de éste a través de la legislación vigente que existe sobre coeducación dentro del currículum educativo en el marco estatal y autonómico. Para conseguir esto, voy a centrarme en la etapa de educación infantil, en la cual niños y niñas de edades comprendidas entre el nacimiento y los seis años comienzan a manejar el mundo de manera simbólica o por medio de representaciones, haciendo construcciones sociales de los objetos y acontecimientos que les rodean ${ }^{7}$. Considero que esta etapa es decisiva en la construcción del sujeto de tal manera que el campo de enseñanza donde niños y niñas interactúan conjuntos es imprescindible para esa construcción y desarrollo, tanto personal como social. No sólo el qué se enseña sino el cómo se enseña, para construir sujetos bajo una perspectiva más igualitaria y no sexista dentro del aula, ayudando a percibir qué prácticas son sexistas en la actualidad y cómo reconocerlas bajo una perspectiva de género.

El marco legislativo educativo en la etapa de infantil contempla escasas leyes sobre educación no sexista, tanto en el aula como en el material escolar empleado; es por ello que quiero centrarme en los cuentos infantiles como parte de la literatura infantil, siendo éstos una herramienta educativa que emplean los colegios y toman de base para el procedimiento de enseñanza tradicional, del que todas las personas hemos formado parte. Los cuentos infantiles son un recurso educativo muy útil para transmitir valores, a la vez que contraproducente puesto que pueden construir conocimientos y

${ }^{7}$ Piaget, Jean. "Etapas del desarrollo", 1967 
conductas alejadas de la realidad, basadas en la tradición y en comportamientos sexistas entre hombres y mujeres, haciendo que niños y niñas asuman esos roles establecidos para cada sexo como reales y verdaderos de esta sociedad, reproduciéndolos en su día a día.

Los cuentos infantiles son parte de la historia, ya sean transmitidos oralmente o de forma escrita; son un recurso utilizado dentro de las aulas (y también fuera de ellas) en la etapa de educación infantil fundamentalmente, aunque también son propios de los primeros cursos de Primaria y Secundaria. Son un mecanismo de socialización y de inculcar valores a las nuevas generaciones, el recurso educativo más potente que la sociedad dispone para socializar y educar, a la vez que cómodo y útil para la gran mayoría de los individuos.

Pero ¿son los cuentos infantiles el mejor recurso visual y escrito para transmitir valores? La primera respuesta que consideraríamos sería un sí, pero muy pocas veces nos preguntamos qué es lo que estamos transmitiendo en realidad, consideramos que es lo correcto porque siempre ha sido así, y nos aferramos a la tradición de nuestra cultura, casi sin ser consciente del problema que ello conlleva.

Nuestra cultura occidental (y no sólo la nuestra) sigue basándose en la reproducción de roles sexistas y discriminatorios hacia las mujeres ${ }^{8}$, que son muy visibles en los materiales didácticos que empleamos dentro del sistema educativo y fuera de éste, perpetuando el rol doméstico de la mujer y el rol público del hombre, mostrando las habilidades consideradas "biológicas e innatas" por las cuales, niños y

\footnotetext{
${ }^{8}$ Tomé, Amparo. "Diagnóstico del centro educativo en materia de igualdad entre hombres y mujeres". En Tomé, Amparo et al. Guía de buenas prácticas para favorecer la igualdad entre hombres y mujeres en educación, 2005, pp. 21
} 
niñas son diferentes y requieren distintos roles estereotipados asignados a su sexo ${ }^{9}$. Es por ello que quiero trabajar sobre los recursos didácticos que utilizamos para transmitir ideas, conceptos, conocimientos, etcétera, del entorno que nos rodea y así comprobar si se acercan a la realidad o no, como por ejemplo los cuentos infantiles.

Todavía, a día de hoy, se continúa empleando la literatura infantil tradicional para transmitir conocimientos y valores de la sabiduría popular ${ }^{10}$ casi sin cuestionar lo que esto implica puesto que contiene un lenguaje sexista, discriminatorio y desigual para la mujer y no sólo la escritura sino también las imágenes. Cantidad de textos didácticos emplean imágenes donde las mujeres son representadas en la esfera privada, en el hogar, donde tradicional e históricamente se ha considerado que era su lugar, con los estereotipos "típicos" asociados a su sexo, sin margen de acción para poder cambiar esta situación de discriminación ${ }^{11}$. Algunos cuentos infantiles a día de hoy han sufrido diversas modificaciones, pero como explicaré más adelante, la mayoría de ellos tienen un patrón muy similar en las mismas líneas sexistas, perpetuando situaciones de desigualdad en las que la mujer continúa por debajo del hombre.

A pesar de la diversidad de doctrinas y corrientes de pensamiento que nos acercan un poco más a esa libertad e igualdad que deseamos y merecemos, como son las teorías feministas y todos los movimientos activistas en su mayoría de mujeres que luchan por una igualdad real, siempre tenemos a nuestras espaldas, este sistema patriarcal que nos envuelve y maneja, a la vez que nos construye y nos guía hacia lo que se considera "correcto", a mi parecer normativo, porque nos exige mantener una

\footnotetext{
${ }^{9}$ Turín, Adela. "Los cuentos siguen contando, algunas reflexiones sobre los estereotipos". Cuadernos inacabados, Madrid: horas y HORAS, 1995, p. 7

${ }^{10}$ Socias, Estela. "Los cuentos tradicionales y los estereotipos sexuales", En http://estelasocias.cl/portal/index.php?option=com content\&task=view\&id=74\&ltemid=42, en línea. 2011

${ }^{11}$ Ibídem, 91
} 
corriente fija y nos obliga a seguir una norma, norma que unos pocos o muchos han decidido con el paso de los años y nos ha sido impuesta bajo la etiqueta de "tradición", y parece ser que lo que es tradición, es inamovible. ${ }^{12}$

Lo mismo ocurre a lo largo de todo el proceso educativo que acompaña al niño y a la niña; éstos se ven inmersos en una cultura y una tradición determinadas lo que conlleva unas normas sociales impuestas y a un sistema educativo que con el paso de los años sufre variaciones. Después de que rompimos las barreras de la escuela segregada $^{13}$ (que no hacía otra cosa que separar a la sociedad en función del sexo biológico) y con la entrada de la escuela mixta desde 1970, se consiguieron muchos propósitos, pero ¿optar a una educación mixta implica un aprendizaje basado en la igualdad y la no discriminación en función del sexo? Hemos podido comprobar que no, que esta educación que reciben niñas y niños posee conocimientos desde la ciencia patriarcal lo que implica formar a un alumnado desde un sistema de enseñanza sexista más que mixto, basado en un modelo masculino y es aquí donde nace la necesidad de convertir el aula en un espacio más igualitario; desde la modificación de los recursos didácticos, las conductas empleadas, los valores transmitidos, hasta el lenguaje utilizado en las aulas, en definitiva, un nuevo sistema educativo o mejor dicho, coeducativo. Es hora de que niñas y niños descubran lo positivo de las formas de vivir, de los comportamientos, de los valores, que históricamente han desarrollado las mujeres y que durante mucho tiempo han sido invisibilizados, cuestionados e infravalorados. ${ }^{14}$

\footnotetext{
${ }^{12}$ Browne, Naima y France, Pauline. "Hacia una educación infantil no sexista”, Madrid: Ed. Morata, 1988, pp. 72

${ }^{13}$ Subirats, Marina y Brullet, Cristina. "La coeducación. Plan para la igualdad de oportunidades para las mujeres", Madrid: Ministerio de Educación y Ciencia, Secretaría de Estado de Educación, 1991, pp. 43 ${ }^{14}$ Urruzola, Ma José. "¿Es posible Coeducar en la actual escuela mixta? Una programación curricular de aula sobre las relaciones afectivas y sexuales", Bilbao: Maite Canal, 1991, pp. 18
} 
La implantación de la escuela mixta desde 1970 en nuestro país ha supuesto un gran avance para la educación de las mujeres, ya que ambos sexos participan de la misma formación y comparten experiencias en las aulas. Pero la actual educación mixta no corrige suficientemente los estereotipos vigentes todavía en nuestra sociedad que adjudican papeles, profesiones y expectativas diferentes en función del sexo de las personas $^{15}$. Tras la aparente igualdad de la educación mixta, aún perviven elementos discriminatorios que siguen moldeando a las mujeres como seres pasivos y dependientes y a los varones como agresivos y dominadores ${ }^{16}$ siendo una realidad que las relaciones desiguales y discriminatorias continúan existiendo a pesar de los indiscutibles avances y de las leyes que exigen un cambio a posiciones más igualitarias dentro del sistema educativo, mediante la implantación de diversas propuestas, como es la coeducación como forma de trabajar las relaciones humanas, una alternativa a los modelos de enseñanza tradicionales y sexistas que reciben los niños y niñas en los colegios; pero la coeducación no debe ser una propuesta educativa alternativa a utilizar en determinadas situaciones o aspectos, sino que debe ser ejecutada de manera transversal y ejercerla desde todos y hacia todos los sectores y ámbitos.

Considero la coeducación como un planteamiento ideológico que apuesta y se fundamenta por un compromiso con la igualdad de género y que todos y todas debemos emplear en nuestro día a día; con ello me refiero a nuestra conducta y comportamiento con respecto a nosotros mismo y hacia los demás, ya sea dentro del sistema educativo como fuera de él. Es una forma de vida que implica la aportación de valores igualitarios en una sociedad desigual y jerárquica que destaca por su carácter discriminatorio en función del sexo principalmente, donde la mitad de la población se encuentra en una

\footnotetext{
${ }^{15}$ Subirats, Marina y Brullet, Cristina. “La coeducación... , obra citada, pp. 43

${ }^{16}$ Ballarín, Pilar. Historia de la..., obra citada, pp. 12 
situación en desventaja, frente a la otra mitad. La coeducación posibilita hacer visible el currículum oculto que poseemos dentro de las instituciones y que considero es más perjudicial y dañino que cualquier otra conducta más visible porque lo llevamos "innato" desde que empezamos a socializarnos y nos acompaña durante nuestros años de aprendizaje; es parte de nuestra cultura y por ello lo consideramos como real y bueno $^{17}$.

Mi propuesta de trabajo pasa por replantearme el actual modelo educativo en la etapa de educación infantil, para lo cual, me resulta necesario revisar si existe o no un compromiso con la educación no sexista o coeducativa en esta etapa a través del análisis de las herramientas literarias y didácticas que se emplean en el aula. A su vez, voy a indicar hasta qué punto los cuentos infantiles tradicionales empleados para educar a niños y niñas transmiten estereotipos de género discriminatorios hacia las mujeres y los varones y si reproducen los mismos modelos de conducta sexistas, en los que se fundamenta nuestra sociedad patriarcal. Me centro en los cuentos infantiles, ya que éstos, pueden ser la mejor herramienta pedagógica para coeducar dentro de la etapa de educación infantil; con ellos quiero argumentar su importancia coeducativa en la construcción social y personal del sujeto y su relevancia en la infancia. En definitiva, voy a estudiar si existe un compromiso coeducativo, dando lugar a la creación de una nueva generación de literatura infantil no sexista.

Pretendo desarrollar estos objetivos, en el transcurso de mi trabajo, para dar respuesta al objeto de mi investigación sobre los cuentos infantiles coeducativos y trabajar sobre el problema de los materiales didácticos sexistas y lo que esto conlleva.

\footnotetext{
${ }^{17}$ C.E.T.P. Intelhorce. "Proyecto de Coeducación: Puedes tú, puedo yo. Creemos una sociedad igualitaria
} desde el aula", Málaga, 2005, pp. 2 
Eliminar los estereotipos de género es una tarea complicada y difícil, ya que ese proceso de construcción de identidades, se produce por la socialización y se justifica bajo la etiqueta de:"porque siempre ha sido así"18 , propio del sistema patriarcal que hace atractivo y llamativo la consecución de los mismos roles estereotipados para cada sexo, donde es muy complicado modificarlos por la presión que la sociedad tiene hacia éstos y los muchos años que llevamos reproduciéndolos bajo la etiqueta de la tradición.

El descontento de ciertos grupos de la sociedad, junto con la crítica feminista, ha conseguido que existan materiales coeducativos a emplear en la formación de niños y niñas, pero: ¿por qué se siguen utilizando los tradicionales cargados de contenidos sexistas? ¿cuál es la barrera que impide que tales materiales coeducativos sean más conocidos y empleados en nuestras aulas?.

Para mi investigación he divido el trabajo en varios capítulos: el primero corresponde al marco teórico, en el que desarrollo la situación actual sobre la legislación estatal y andaluza a nivel de educación, para revisar qué leyes abordan el tema de la igualdad entre hombres y mujeres, de obligado cumplimiento en los centros escolares. Con ello quiero comprobar, si la normativa institucional atiende a temas de igualdad, principalmente en la etapa de infantil y saber bajo qué leyes trabajan los colegios en materia de coeducación.

También es relevante para mi investigación hacer una revisión de los estudios de magisterio infantil de todas las universidades españolas, para comprobar si el Plan de Grado desarrollado en cada universidad contiene materias relacionadas con la coeducación y la literatura infantil.

\footnotetext{
18 Toral, Yolanda y Valverde, Miguel A. "Participación y Contribución de la familia, el profesorado y el alumnado para mejorar la convivencia en los centros". EN Tomé, Amparo. Guía de buenas prácticas para favorecer la igualdad entre hombres y mujeres en educación, 2005, pp. 47
} 
$\mathrm{Y}$, finalmente, dentro de este capítulo, tengo en cuenta el estudio de proyectos coeducativos, donde expongo qué es la coeducación, cómo se articula y desarrolla dentro del sistema educativo y del currículo oculto. La importancia de trabajar en la etapa de educación infantil, la construcción de identidades en el sujeto y cómo la coeducación trabaja para construir nuevos materiales didácticos sin carácter sexista en su contenido y potenciando la igualdad entre hombres y mujeres.

Tras la parte teórica, desarrollo el capítulo metodológico, donde he incluido un apartado exclusivo sobre la metodología que voy a emplear en mi investigación. En él expongo las técnicas que he utilizado para realizar el capítulo de análisis de cuentos infantiles y el proceso que voy a llevar a cabo para realizar la parte empírica de mi trabajo.

Tras exponer que metodología voy a utilizar el siguiente capítulo hace referencia al desarrollo y utilización de las técnicas expuestas anteriormente, para conocer así el nivel de compromiso de la literatura infantil utilizada en algunos centros como herramienta para transmitir valores coeducativos; por tanto comienzo con una revisión de los cuentos coeducativos como fuente de análisis para el estudio de aspectos coeducativos, al margen de los modelos de conducta tradicionales y sexistas que destacan en la literatura infantil tradicional. Para ello analizaré los estereotipos aplicados a cada sexo, las imágenes que se muestran, el lenguaje utilizado y los valores que se enseñan a través del cuento.

Más tarde, finalizo con el capítulo de "conclusiones", donde expongo si he conseguido responder a mis preguntas de investigaciones planteadas a lo largo del análisis y si he conseguido desarrollar los objetivos que he planteado al principio de mi trabajo. 
Tras desarrollar las conclusiones y resultados de mi análisis, en el apartado de "anexos", me centro en el estudio y análisis de diversas plataformas en soporte visual a través de internet como son las revistas electrónicas y las colecciones de libros para infantil y juvenil donde presentan cuentos coeducativos, así como diferentes editoriales que trabajan la coeducación en sus materiales didácticos. Para ello voy a comprobar que dinámica emplean las webs para trabajar este tipo de literatura y si dedican algún epígrafe exclusivo para cuentos dedicados a la igualdad de género. Es necesario revisar las editoriales con las que trabajan los colegios para controlar qué materiales didácticos distribuyen, porque de ellas dependerán los materiales empleados dentro del aula, y así comprobar si estos son coeducativos o no lo son.

El último apartado de mi investigación, consiste en la parte bibliográfica y fuentes documentales utilizadas para realizar y desarrollar mi trabajo.

En definitiva, pretendo demostrar la importancia de trabajar la coeducación como propuesta pedagógica a utilizar dentro del sistema educativo, para hacer visible el sexismo que perdura tanto en la escritura como en el lenguaje y las imágenes; sobre todo de los materiales didácticos empleados en las aulas (y fuera de éstas) y más concretamente en los cuentos infantiles y así erradicar comportamientos y conductas sexistas en el imaginario social de los niños y niñas de infantil, para potenciar un aprendizaje bajo una línea coeducativa donde ambos se eduquen en igualdad real. 


\section{2.- LA COEDUCACIÓN EN EDUCACIÓN INFANTIL Y EN EL CURRÍCULUM.}

"Las actitudes del profesor ante su profesión resulta primordial para entender muchos aspectos relacionados con el tema que nos interesa. No solamente el sexismo, sino cualquiera de las cuestiones que se debaten hoy relacionadas por la autopercepción del enseñante en su medio profesional"

Inés Alberdi y Pilar, Escario. Vida Privada y Trabajo. En Mujer e Igualdad de oportunidades en el empleo, 1989.

Con frecuencia, en la educación infantil, los y las docentes son resistentes a pensar que se dé una educación discriminatoria por razón de sexo; sin embargo, la inexistencia en el currículo educativo sobre cualquier tipo de discriminación no evita que en la práctica en sí no aparezcan otras formas discriminatorias de carácter cultural. ${ }^{19}$ Por ello la necesidad de explicitar aquellos elementos que configuran el día a día de la educación infantil, como en cualquier otra etapa educativa, que actúan como transmisores de estereotipos sexistas y comportan consecuencias negativas para ambos sexos.

Desde que fue creado el Instituto de la Mujer en 1982, entre sus competencias principales ha destacado la lucha por conseguir la igualdad entre hombres y mujeres

\footnotetext{
${ }^{19}$ A.D.E.N.U. (Asociación de Docentes y Educadores No Universitarios). Sexismo en la escuela de Educación Infantil 
posibilitando estudios que abordaran a lo largo de los últimos 30 años la cuestión del sexismo dentro del sistema educativo, qué leyes amparan y reflejan una educación igualitaria, es decir, coeducativas para todos y todas, y qué recursos no sexistas se emplean en el aula para enseñar en igualdad; también han demostrado estos estudios que el sistema educativo que tenemos, que se define bajo la etiqueta de igualitario para todos y todas reproduce elementos discriminatorios que continúan moldeando a las mujeres como seres pasivos y dependientes. Todos ellos abordan el tema desde una perspectiva de género, cuestionando el modelo educativo en el cual se basa nuestra enseñanza e intentando ser capaces de detectar aquellos comportamientos, lenguajes y conductas sexistas.

Para empezar con el desarrollo de mi investigación es necesario plantearme qué hay hecho hasta la fecha y así poder situarme ante el problema; para ello considero necesario partir de la legislatura vigente en educación y qué existe sobre educación no sexista dentro del marco político que tenemos. Es importante hacer referencia al marco legislativo tanto a nivel español como andaluz para revisar las leyes existentes en educación; de este modo podré observar qué normativas precisan de contenido igualitario que potencian una educación no sexista a desarrollar en el aula y sean cumplidas por las directrices de los colegios. Quiero comprobar los compromisos institucionales con la reglamentación de los centros, con la igualdad, con su cumplimiento y comprobar cómo recogen esta cuestión para regularla y reglarla en los centros educativos.

Una vez revisado el marco legislativo en materia educativa, es conveniente analizar la formación que tiene el profesorado en educación infantil mediante la observación del currículo que presenta la titulación de magisterio en educación infantil. En función de la distribución y de las asignaturas del plan de estudio de dicha carrera 
universitaria podré analizar la formación que están recibiendo hombres y mujeres encargados y encargadas, en un futuro, de la educación de niños y niñas en la etapa de infantil. De esta forma comprobaré si existen materias que presenten un contenido coeducativo o relacionado con la igualdad de género y si se fomenta el estudio y aprendizaje de literatura infantil aplicada a niños y niñas de entre 0 y 6 años de edad, ya que esto implicaría que existiera concienciación por parte de la institución y de los profesionales de la educación en tratar la igualdad de género dentro de las aulas y un compromiso de erradicar problemas de sexismo en educación.

En la última parte de este bloque expongo el análisis teórico sobre las apuestas y los significados de lo que implica la coeducación como metodología y como ideología escolar es decir, que voy a centrar el análisis en los discursos actuales sobre esta cuestión: ¿qué se entiende por coeducación?, ¿cómo la sociedad recibe este concepto como nueva propuesta educativa basada en la igualdad de género y la no discriminación?. Para ello voy a apoyarme en teorías, artículos, guías que traten del actual proceso coeducativo que está infiriendo sobre la educación mixta y toda la evolución que ha sufrido este concepto a lo largo de la historia de la educación. 


\section{* 2.1.- LEGISLACIÓN Y COEDUCACIÓN: UNA RELACIÓN COMPLEJA.}

El marco legal nos muestra los compromisos que tiene el Estado con las instituciones, por ello la importancia de revisar aquellas leyes que hacen referencia a las educativas, para comprobar, en este caso, si existe responsabilidad en el cumplimiento de sus obligaciones ante una educación igualitaria para toda la ciudadanía. Quiero mostrar si las leyes educativas hacen referencia a propuestas coeducativas de carácter obligatorio dentro de los centros escolares y si existe un compromiso con los principios de igualdad de género en educación.

En este apartado voy a recoger las leyes existentes en educación a nivel estatal y autonómico por las que se rigen las directrices de los centros educativos, para comprobar el compromiso educativo que poseen en coeducación, así como la revisión de reglamentos, normativas y reales decretos que existen sobre educación igualitaria entre hombres y mujeres. Es necesaria, además, la revisión de la legislación vigente como fuente de análisis, para conocer qué compromiso tiene la institución sobre educación en materia de igualdad aplicada a los centros escolares, porque de ahí dependerá el funcionamiento interno de los centros de enseñanza basados en un aprendizaje igualitario entre niños y niñas y atendiendo a unos principios no sexistas y coeducativos.

Quiero detenerme a revisar la LEY ORGÁNICA 2/2006, de 3 de mayo, de EDUCACIÓN (BOE núm. 106, Jueves 4 mayo 2006, pp.50), es la norma legal sobre educación a nivel español que rige los principios y actuaciones que deben llevarse a cabo dentro del sistema educativo y por las que las comunidades autónomas deben tomar como base y referencia para sus leyes autonómicas en educación. Es importante recoger los principios generales y específicos que aparecen en ella, para comprobar 
cuáles atienden a temas de igualdad entre niños y niñas, cuáles puedan ser desarrolladas por las respectivas autonomías con carácter obligatorio y analizar qué grado de compromiso tienen con respecto a una educación no sexista y coeducativa en educación infantil, puesto que esta etapa es mi objeto de estudio.

Esta ley establece una serie de principios y fines relacionados con la educación en igualdad entre hombres y mujeres. Son los Art. ${ }^{20} 1$ y 2 los que hacen alusión al fomento de una igualdad efectiva y real entre hombres y mujeres y al desarrollo de una igualdad de derechos y oportunidades, comprometiéndose a potenciar una educación basada en el respeto de los derechos y libertades fundamentales y en la igualdad de derechos y oportunidades entre hombres y mujeres.

Y tan solo, en su disposición adicional vigesimoquinta ${ }^{21}$, esta ley hace mención al término "coeducación" como propuesta pedagógica. Establece como fin principal favorecer la igualdad de derechos y oportunidades, fomentar la igualdad efectiva entre hombres y mujeres, además de que los centros que desarrollen el principio de coeducación en todas las etapas educativas, serán objeto de atención preferente y prioritaria en la aplicación de las previsiones recogidas en la presente ley [...]

En esta ley, quedan recogidos escasos aspectos sobre educación en materia de igualdad entre hombres y mujeres de obligado cumplimiento en el currículo educativo de los centros escolares, de las respectivas comunidades autónomas. La Ley General de Educación es la normativa de carácter nacional que rige los objetivos y principios básicos por lo que debe guiarse y fundamentarse el sistema educativo. Éste debe ser capaz de proporcionar una educación de calidad a toda la ciudadanía española de ambos

\footnotetext{
${ }^{20}$ Principios de la LEY ORGÁNICA 2/2006, de 3 de mayo, de EDUCACIÓN (BOE núm. 106, Jueves 4 mayo 2006, pp.50), pp.7-8

${ }^{21}$ Disposición adicional vigesimoquinta. Fomento de la igualdad efectiva entre hombres y mujeres. En LEY ORGÁNICA 2/2006... pp.43
} 
sexos, para que éstos alcancen el máximo desarrollo posible de todas sus capacidades, individuales, sociales, intelectuales, culturales y emocionales, adaptadas a sus necesidades. Esta ley tiene en su contenido educativo principios orientados hacia la consecución de valores tales como, la libertad personal, la responsabilidad, la ciudadanía democrática, la solidaridad, la tolerancia, la igualdad, el respeto y la justicia. La consecución de estos valores es obligatoria en todas las etapas educativas: infantil, primaria, secundaria, bachillerato, formación profesional, enseñanza de idiomas, artística, deportiva, de personas adultas y universitarias. Acotando mi estudio a la etapa de educación infantil y comparándola con el resto de etapas, compruebo que no existen principios ni objetivos que consideren el tema de la igualdad entre hombres y mujeres, ni prácticas coeducativas para dicha etapa; tan solo centra su atención en la adquisición de autonomía personal, desarrollo de capacidades afectivas y comunicativas y pautas de convivencia y relación social con los demás. Tan sólo en la etapa de educación primaria contempla como uno de los objetivos principales: conocer, comprender y respetar las diferencias entre todas las personas, la igualdad de derechos entre hombres y mujeres y la no discriminación de personas con discapacidad ${ }^{22}$, obviando este objetivo para la etapa de educación infantil.

De entre las normas legales que han tenido especial eco en las demandas sociales y que mayores consensos han recabado dentro de la clase política la, Ley Orgánica 3/2007, de 22 de marzo, para la igualdad efectiva de mujeres y hombres (BOE núm.71, Viernes 23 marzo 2007, pp.12611-12645), ha reflejado como prioritario la igualdad efectiva entre ambos sexos dentro del ámbito educativo. En los artículos 23 y 24 se destaca como objetivo principal dentro de la educación el fomento de la igualdad real entre mujeres y hombres, eliminando cualquier barrera para conseguirla, a la vez que

${ }^{22}$ Objetivo de la educación primaria. En LEY ORGÁNICA 2/2006... pp.11 
hace referencia a las Administraciones educativas, las cuales deberán comprometerse a eliminar aquellos estereotipos sociales sexistas asociados para cada sexo. Se incluye una serie de actuaciones propuestas a desarrollar dentro de esta administración. La expresión literal queda recogida así: artículo 24. e) La cooperación con el resto de las Administraciones educativas para el desarrollo de proyectos y programas dirigidos a fomentar el conocimiento y la difusión, entre las personas de la comunidad educativa, de los principios de coeducación y de igualdad efectiva entre mujeres y hombres ${ }^{23}$.

Estos dos artículos 23 y 24 del capítulo II exigen que tanto el sistema educativo como las administraciones públicas se comprometan a la eliminación de aquellas barreras que impidan una igualdad real entre hombres y mujeres en educación, así como la supresión de componentes, contenidos, comportamientos y estereotipos sexistas en el currículo educativo. También se hace hincapié a la cooperación entre las demás administraciones educativas para llevar a cabo proyectos y programas que permitan una educación en igualdad aplicando principios coeducativos y de igualdad entre hombres y mujeres a aquellas personas que forman parte de la comunidad educativa.

Esta Ley Orgánica establece el fundamento jurídico para avanzar hacia la efectiva igualdad en todos los ámbitos de la vida social, económica, cultural y política, para lo cual se requiere de un Plan Estratégico por parte del Gobierno, para concretar cuáles son los objetivos y medidas de actuación en los que los poderes públicos deben centrar sus actuaciones. Es aquí donde surge el Plan Estratégico de Igualdad de Oportunidades (2008-2011) creado en Diciembre de 2007, para conseguir no solo una igualdad legal sino también real y efectiva entre hombres y mujeres.

\footnotetext{
${ }^{23}$ Artículo 24. Integración del principio de igualdad en la política de educación. En Ley Orgánica 3/2007, de 22 de marzo, para la igualdad efectiva de mujeres y hombres (BOE núm.71, Viernes 23 marzo 2007, pp.12611-12645), pp.12616
} 
Este plan se sustenta en dos principios básicos: no discriminación e igualdad, desarrollando sus objetivos y propuestas en cuatro principios rectores: la redefinición del modelo de ciudadanía, el empoderamiento de las mujeres, la transversalidad de la perspectiva de género y la innovación.

He escogido este plan estratégico porque a través de estos cuatros principios rectores queda explícita la necesidad de eliminar cualquier situación de discriminación hacia las mujeres además de potenciar la riqueza de la sabiduría femenina, visibilizándolas a lo largo de la historia, tomando como referencias sus experiencias, aportaciones y conocimientos.

Este plan incluye en su desarrollo doce ejes de actuación. De éstos voy a mencionar el eje 4 y el más importante para mi investigación: Educación. Este punto establece una serie de objetivos y actuaciones donde los poderes públicos deben centrar su actuación prioritaria. Sus objetivos dentro de este eje se basan en la necesidad de dar una formación adecuada a los profesores y profesoras en aspectos coeducativos, de violencia de género y de igualdad de oportunidades entre hombres y mujeres. Este objetivo supone revisar la formación que recibe el personal docente encargado de una enseñanza basada en el principio de igualdad entre hombres y mujeres. A su vez también contempla la necesidad de utilizar proyectos coeducativos dentro del currículo del centro escolar y la revisión de los textos y materiales didácticos bajo una mirada de género para erradicar cualquier componente sexista que aparezcan en ellos, incorporando las aportaciones y saberes de las mujeres en sus contenidos. Este es un objetivo clave para mi trabajo ya que voy a revisar si en la etapa de educación infantil existe un compromiso con la educación no sexista o coeducativa y más concretamente en el análisis de herramientas literarias y didácticas empleadas en dicha etapa. 
La implicación de las instituciones públicas y los gobiernos en temas de igualdad ha dado lugar a la elaboración de leyes específicas de género, como la Ley Orgánica 1/2004, de 28 de Diciembre, de Medidas de Protección Integral contra la Violencia de Género, (BOE núm.313, Miércoles 29 diciembre 2004, pp.42166-42197), la cual dispone de un capítulo dedicado exclusivamente al ámbito educativo. Este capítulo se centra en la obligatoriedad que tiene el sistema educativo para incluir dentro de sus fines la formación en el respeto de los derechos y libertades fundamentales así como de la igualdad de hombres y mujeres, erradicando cualquier situación de conflicto bajo el ejercicio de la tolerancia y libertad de expresión a través de la resolución pacífica de los mismos. El sistema educativo se comprometerá al ejercicio de tales fines en todas las etapas educativas, con orientaciones hacia la no discriminación por razón de sexo y la igualdad efectiva entre hombres y mujeres en la etapa de educación primaria, secundaria, bachillerato, formación profesional, formación de personas adultas y universidades, es aquí donde no se aprecia su desarrollo en la etapa de educación infantil; tan solo hace referencia a esta etapa el aprendizaje de la resolución pacífica de conflictos sin considerar el principio de igualdad entre hombres y mujeres.

También establece, como objetivos propuestos, la revisión de materiales didácticos, para eliminar comportamientos sexistas derivados de una enseñanza discriminatoria hacia la mujer y la formación del profesorado bajo una visión de género.

Igualmente resulta de interés estudiar la Ley Orgánica de 4/2007, de 12 de abril, por la que se modifica la Ley Orgánica 6/2001, de 21 de diciembre, de Universidades (BOE núm.89, Viernes 13 abril 2007, pp.20). Esta ley resulta de interés porque corresponde al primer compromiso institucional en herramientas coeducativas dentro del sistema educativo, más concretamente en el ámbito universitario. Esta ley tiene como objetivo principal alcanzar una sociedad tolerante e igualitaria, en la que se 
respeten los derechos y libertades fundamentales así como la igualdad entre hombres y mujeres en las universidades, introduciendo programas específicos sobre igualdad de género. Al mismo tiempo propone con unidades específicas de igualdad para el desarrollo de las funciones relacionadas con el principio de igualdad entre mujeres y hombres. Puesto que mi segundo apartado consiste en una revisión de la formación del profesorado universitario dentro de la titulación de magisterio infantil, es necesario conocer qué ley ampara y garantiza el principio de igualdad de género dentro de los planes de estudios de las universidades españolas; aunque esta ley la utilizaré y desarrollaré con más exactitud en el próximo apartado.

Al igual que es necesario revisar la Ley General de Educación para ver los compromisos que ésta tiene en materia de igualdad en educación, también habrá que revisar dicha ley, aplicada a las Comunidades Autónomas. La LEY 17/2007, de 10 de diciembre, de Educación de Andalucía (BOJA núm.252, Sevilla, 26 de diciembre de 2007, pp.32), teniendo por objeto la regulación del sistema educativo andaluz y de su evaluación, como el fomento de la participación de la sociedad y las instituciones en el ejercicio de las competencias de dicha comunidad autónoma y en el marco de las bases establecidas por el sistema educativo español. Dicha ley consta de unos objetivos a cumplir por la Comunidad Autónoma Andaluza al igual que la Ley Orgánica de Educación de 2/2006 de 3 de mayo. Como objetivos a cumplir destaco aquellos que se refieren a una educación igualitaria entre hombres y mujeres dentro del marco educativo, garantizando una igualdad efectiva de oportunidades para ambos sexos a través de una educación en valores, destacando la importancia de los saberes femeninos dentro del currículo educativo.

Refiriéndome al Capítulo II sobre Educación Infantil, puedo observar que no existe ningún apartado que centre su actuación en materia de igualdad y no 
discriminación dentro del currículo de educación infantil. Si observamos el currículo de educación primaria podemos constatar que existen principios dedicados al tema de igualdad de oportunidades entre hombres y mujeres, dejando ver que no se considera relevante educar en igualdad dentro del marco de infantil o al menos, no con el suficiente peso para tener aprobación normativa, lo mismo que ocurría en la ley general de educación a nivel estatal.

Es necesario mencionar la Ley 12/2007 de 26 de Noviembre para la Promoción de la Igualdad de Género en Andalucía (BOJA núm. 247, Sevilla, 18 de diciembre 2007, pp.11), ya que además de suponer una ley específica de igualdad de género, establece un apartado referido a la igualdad en educación donde la administración educativa y centros escolares se comprometen a fomentar una educación en igualdad entre hombres y mujeres, potenciando una participación equilibrada de mujeres y hombres en los puestos directivos y de decisión. Esta ley pone de manifiesto las distintas formas de discriminación que han sufrido las mujeres a lo largo de la historia y su papel en la consecución de una igualdad real de oportunidades, además supone contribuir a la superación histórica de la desigualdad de la mujer en Andalucía, desigualdad que afecta a la mitad de la población, lo que exige un mayor compromiso por parte de los poderes públicos en el marco de un Estado social y democrático de Derecho. A su vez, la administración garantizará la puesta en marcha de proyectos coeducativos dentro de los centros escolares, para conseguir así erradicar la discriminación por razón de sexo y eliminar los comportamientos sexistas y situaciones de violencia de género. Es importante revisar esta Ley porque incluye la utilización de proyectos coeducativos como una propuesta educativa para trabajar contra el sexismo en educación. Se compromete también dicha Ley a la contratación de una persona responsable con formación específica en coeducación, que trabaje mediante actuaciones 
y actividades dirigidas a la persecución de una igualdad real entre hombres y mujeres bajo una mirada de género. Es por ello que analizo este apartado de dicha Ley, porque recoge en sus fines la importancia de trabajar bajo una mirada de género a través de proyectos coeducativos para fomentar la igualdad entre hombres y mujeres en todas las etapas educativas. La importancia de regular esta ley ya que trabaja sobre violencia de género, igualdad de oportunidades entre hombres y mujeres, coeducación y educación sexual. Además de establecer en su artículo 7 uno de los elementos para alcanzar el objetivo de la igualdad entre mujeres y hombres y para eliminar la discriminación por razón de sexo, la elaboración de un Plan Estratégico de Igualdad de Mujeres y Hombres cada cuatro años.

Desde el Gobierno de la Comunidad Autonómica de Andalucía se han realizado las actuaciones necesarias para dar cumplimiento a lo establecido en la mencionada Ley 12/2007, aprobando el I Plan Estratégico para la Igualdad de Mujeres y Hombres en Andalucía 2010-2013 (MHA). Éste no sólo desarrolla y hace efectivo el cumplimiento de dicha Ley sino que trata de consolidar las líneas de trabajo puestas en marcha en el $I$ Plan de Igualdad entre Hombres y Mujeres en Educación de $2005^{24}$.

El presente Plan pretende alcanzar una sociedad igualitaria, justa, solidaria y democrática en la que las mujeres $\mathrm{y}$ hombres tengan los mismos derechos $\mathrm{y}$ oportunidades, teniendo como objetivo principal garantizar que los poderes públicos se comprometan al cumplimiento de la transversalidad como un instrumento indispensable para que las comunidades autónomas ejerciten sus competencias en materia de género. Esta ley requiere la aprobación de un plan estratégico cada cuatro años y es aquí donde surge el I Plan Estratégico para la Igualdad entre Hombres y Mujeres en Andalucía

\footnotetext{
${ }^{24}$ I Plan de igualdad entre hombres y mujeres en educación. Consejería de Educación de la Junta de Andalucía. 2 de Noviembre de 2005, pp.60
} 
2010-2013 cuyo objeto de actuación es garantizar la igualdad real y efectiva en los derechos y en las obligaciones de las mujeres y los hombres andaluces.

Este Plan se basa en seis principios rectores: Igualdad real y efectiva y no discriminación, responsabilidad, visión de proceso, repercusiones en la ciudadanía, Instrumentalidad e innovación. La función principal de este plan es estratégica, es decir, definir cuáles son las directrices estratégicas desde donde se quiere partir para conseguir una igualdad efectiva llevada a cabo por la Comunidad Autonómica Andaluza.

Son tres las directrices estratégicas definidas por este Plan: Transversalidad de género, corresponsabilidad y empoderamiento de las mujeres. Para poder llevar a cabo estas directrices se han establecido ocho líneas de actuación, siendo la Educación la más relevante e importante para mi trabajo. Quiero destacar los objetivos 1, 2 y 4 dentro de la línea de actuación en Educación:

- 1.3: Obligatoriedad del uso del lenguaje inclusivo, no sexista en toda la documentación y cartelería de los centros educativos.

- 1.8: Elaboración de instrucciones y orientación en relación con los criterios de selección y edición de materiales curriculares, desde la perspectiva de género, en la medida de asegurar la eliminación del sexismo en ellos.

Es necesaria una revisión del lenguaje tanto oral como escrito, reflejado en los materiales didácticos empleados en los contextos educativos, para evitar la transmisión de cualquier mensaje sexista al alumnado. Éstos objetivos están relacionados con el trabajo que analizo, porque parte de él consiste en la revisión del lenguaje y de la escritura empleada en los materiales didácticos de infantil para comprobar el compromiso con la coeducación. 
- 1.5: Impregnar de perspectivas de género el Plan Tutorial que afecta obligatoriamente a la totalidad del alumnado, tanto en la educación infantil y primaria como en la educación secundaria.

Es imprescindible que todos los programas y planes por los cuales se guía y en los que se basan los centros educativos tengan una perspectiva de género que incluyan a todo el alumnado bajo un marco igualitario desde donde trabajar y como punto de partida para erradicar el sexismo. Estas perspectivas de género son requisito imprescindible para trabajar en proyectos coeducativos dentro de las aulas y dicho objetivo cumple con el compromiso que he adquirido para mi trabajo puesto que es necesario que todas las etapas educativas, incluida la de infantil, se desarrollen bajo una mirada de género.

\section{- 1.6: Desarrollo de pautas de intervención coeducativas para la etapa 0-3 años.}

En todo lo referido hasta aquí con respecto a las normas legales, la coeducación es una propuesta que se trabaja muy poco o casi nada en la etapas educativas y mucho menos en educación infantil. Considero por tanto, que es en esta etapa donde hay que comenzar con una educación bajo el respeto y la igualdad para establecer unas líneas de trabajo coeducativas y no sexistas hacia las siguientes etapas académicas.

- 1.9: Incorporar al currículum de las diferentes asignaturas un tratamiento inclusivo con las aportaciones de las mujeres a los diferentes campos del saber, así como la reflexión sobre sus ausencias o presencia sesgada como consecuencia histórica de su exclusión.

La mayoría de los materiales académicos no reflejan la trayectoria de las mujeres a lo largo de la historia, ni encontramos mujeres que hayan destacado en alguna 
materia, ya sea ciencia, lengua, tecnología, política, etcétera, siendo invisibilizadas. Con frecuencia encontramos los nombres de personajes famosos varones que sirven como punto de referencia en los hitos históricos más importantes. Es necesario que las mujeres sean visibilizadas en los documentos mostrados en el sistema educativo, mostrándolas como sujetos activos que forman parte del proceso histórico. Este objetivo cumple con el propósito para mi investigación porque en la parte metodológica analizo los materiales didácticos, más concretamente los cuentos infantiles y centro un apartado al lugar que ocupan las mujeres en ellos.

\section{- 2.7: Actuaciones para que en los cursos de formación del funcionariado docente} en prácticas, se incluya formación específica en Género y Coeducación.

En este apartado se establece la necesidad obligatoria de que el personal docente se construya bajo una perspectiva de género y reciba una formación específica en temas de mujeres y de igualdad. Es imprescindible que esto sea una realidad en los centros educativos, porque aunque los materiales didácticos no fueran sexistas y representaran por igual a las mujeres y a los hombres, el criterio propio del personal educativo influye decisivamente en la enseñanza hacia los niños y niñas, por ello se necesita un aprendizaje sobre coeducación y visión de género en los que enseñar a educar sin prejuicios ni estereotipos sino en igualdad y tolerancia. Este apartado está relacionado con mi trabajo porque en el siguiente capítulo, reviso los planes de estudios que siguen los futuros docentes en la carrera universitaria de maestro y maestra de educación infantil, qué y cómo se les enseña y qué asignaturas estudian.

- 4.1: Promover una perspectiva equilibrada de las mujeres en toda su diversidad, (edad, clase social, discapacidad, etcétera), en el material curricular y libros de texto, a través de su contribución en las distintas facetas 
de la historia, ciencia, política, cultura y desarrollo de la sociedad e incluir el estudio del feminismo como pensamiento político y movimiento social, así como la revisión del currículo, del lenguaje coeducativo y las imágenes.

Al igual que en el objetivo 1, es necesaria la visibilización de las mujeres en los libros de texto así como de toda la historia del feminismo y la lucha de las mujeres por conseguir el reconocimiento de sus derechos. El estudio del feminismo debe reflejarse en los libros de texto y bajo esta afirmación elaboro parte de mi metodología cuando analizo los libros de textos empleados en los centros escolares.

- 4.2: Promover la desaparición en los materiales curriculares y libros de texto de prejuicios culturales y estereotipos sexistas o discriminatorios, para ello se darán instrucciones a los Centros Educativos, Editoriales y Consejos Escolares en lo referido a la utilización de un lenguaje, contenidos, imágenes y actividades no sexistas y no excluyentes.

Se reitera la necesidad de una revisión exhaustiva de los libros de texto para erradicar el sexismo y cualquier tipo de discriminación por razón de sexo, raza, edad, etcétera, en los materiales empleados. Es imposible llegar a un educación con orientaciones coeducativas en su desarrollo sin la revisión y eliminación de contenido sexistas y discriminatorio en función del sexo.

Este Plan implica una visión coeducativa de la actuación escolar, la relación entre sus miembros y la puesta en marcha de medidas para visibilizar y diagnosticar los problemas de sexismo, a la vez que trabaja para conseguir una igualdad efectiva entre hombres y mujeres en educación con la eliminación de materiales curriculares y didácticos que presenten estereotipos sexistas hacia las mujeres, incidiendo en la erradicación de modelos en los que aparezcan situaciones de desigualdad y violencia de 
género, valorando aquellos materiales que mejor respondan a la coeducación entre los niños y niñas.

Tras la revisión del marco legislativo por el que se guía nuestro sistema educativo y comprobar que apenas existen normativas con carácter obligatorio que garanticen una educación basada en proyectos coeducativos, principalmente en la etapa de educación infantil, centro mi atención en el documento más importante a día de hoy para conseguir una igualdad entre hombres y mujeres en educación. Este es el I Plan de Igualdad entre hombres y mujeres en educación ${ }^{25}$.

Este documento elaborado en Andalucía, trata la coeducación dentro de las aulas, haciendo un balance de las distintas situaciones discriminatorias en función de sexo que se perciben actualmente en el centro educativo. Comienza con estadísticas y gráficos sobre los porcentajes de alumnos y alumnas que estudian por curso académico, las carreras y puestos directivos que ocupan las mujeres y los hombres, etcétera. Una síntesis de en qué grado de igualdad nos encontramos en educación, haciendo un breve resumen sobre la ley que aprobó este Plan y el por qué de un cambio en el sistema educativo para favorecer una igualdad real entre hombres y mujeres bajo una mirada crítica de género y denunciar así el problema de las desigualdades en educación entre mujeres y hombres en Andalucía.

Este plan refleja la situación de discriminación y desigualdad de género que aún a día de hoy encontramos dentro del sistema educativo, tanto en sus proyectos curriculares como en los puestos directivos, en los materiales didácticos empleados o en la elección de itinerarios académicos en función del sexo; en todas ellas se percibe claramente una situación de desigualdad y discriminación con respecto a la mujer.

\footnotetext{
25 I Plan de igualdad entre hombres y mujeres en educación. Junta de Andalucía, Conserjería de Educación. Sevilla, España, 2 de Noviembre 2005
} 
Según los datos obtenidos a través de dicho Plan, los cuales reflejan una situación de desventaja de la mujer en educación frente al varón, a la vez que se continúa empleando materiales didácticos sexistas dentro de las aulas, invisibilizando la historia de las mujeres y los saberes y conocimientos aportados por ellas. Este Plan lleva implantado 7 años dentro de la Comunidad Autónoma Andaluza y ha promovido un cambio en cuanto a la concienciación y formación de docentes, recursos y materiales, y en el nivel curricular, responsables de coeducación en los centros de secundaria, así como, ha denunciado públicamente desde una mirada de género, la situación actual de los centros escolares ante la igualdad de género.

Por esta razón he analizado este documento como el más importante para la elaboración de mi investigación, ya que muestra con exactitud la situación actual en educación, reflejando el grado de compromiso de los organismos públicos en propuestas coeducativas en las aulas, bajo una visión de género y los datos que muestran la situación de desigualdad y discriminación por sexo que se percibe en las aulas en todas las etapas educativas, impidiendo una igualdad real entre hombres y mujeres en educación. 


\section{* 2.2.- EL CURRÍCULO EN LA FORMACIÓN DEL PROFESORADO:}

\section{CAMBIOS QUE NO LLEGAN.}

La Ley Orgánica 2/2001, de 21 de Diciembre, de Universidades obliga la formación de unidades de igualdad en todas las universidades del territorio español, dando un compromiso institucional en herramientas coeducativas para formar a una sociedad igualitaria y tolerante, introduciendo en las universidades programas específicos de Igualdad de Género.

El currículum se ha revelado en los estudios pedagógicos como el contexto donde se trabajan cuestiones relativas a las implicaciones de la función docente y la formación necesaria para llevarlas a cabo. Para entender cuál es la implicación del profesorado en temas relacionados con la igualdad de género y propuestas coeducativas dentro del aula parece sumamente importante dirigir la mirada al panorama de la formación del profesorado y las políticas académicas de transformación del pensamiento y de la práctica sexista dentro del currículum de cada universidad para ello es necesario una revisión del plan de estudios correspondiente a la carrera de profesor y profesora de educación infantil en las universidades de todo el marco español, para comprobar que asignaturas desarrollan en su contenido curricular y constatar así cuales de ellas mantienen un compromiso con la coeducación y la literatura infantil. Por ello paso a revisar las distintas universidades españolas y elaborar un listado de asignaturas coeducativas y relacionadas con la literatura infantil; tras esto realizo una breve síntesis del recorrido educativo que ha sufrido España desde los años 70 en adelante para elaborar un discurso sobre la construcción de géneros y modelos de hombres y mujeres en la escuela, dando lugar a distintas formas de discriminación en la que las mujeres han sido invisibilizadas principalmente a través del lenguaje (en todas sus formas), por ello 
la necesidad de realizar un estudio orientativo de la formación que reciben los futuros docentes de educación infantil.

Es necesario revisar y contemplar la formación en magisterio infantil que recibe el alumnado universitario a lo largo de la titulación, no sólo para comprobar si existen materias relacionadas con la coeducación dentro del plan de estudios de dicha formación ${ }^{26}$, sino también qué implica que existan éstas dentro del currículum universitario, entendiendo por esto un compromiso con la Igualdad de Género en Educación. Considero relevante e imprescindible para mi investigación analizar cuál es el plan de estudios que lleva a cabo la titulación de magisterio infantil para comprobar las asignaturas que se imparten y así revisar si éstas poseen contenido en igualdad y coeducación, porque además de analizar los materiales didácticos que se imparten en el aula también es importante saber cómo se enseñan a los futuros docentes de infantil, para trabajar posteriormente bajo una visión de género con los niños y niñas.

He revisado la titulación de maestro y maestra en educación infantil de aquellas universidades del territorio español, tanto públicas como privadas, que incluyen Facultades o Centros dedicados a la formación del profesorado, para elaborar un perfil de asignaturas que proponen y forman en coeducación y su enseñanza está relacionada con la literatura infantil y la elaboración de material no sexista. Con el listado de materias seleccionadas que trabajen en su contenido aspectos coeducativos, podré comprobar que compromiso tienen las universidades en su currículo académico, con temas relacionados con la igualdad entre mujeres y hombres, ya que de ahí dependerá que en el futuro dichos docentes impartan las asignaturas y el desarrollo de las clases con una visión de género; también quiero revisar qué asignaturas se centran en la

\footnotetext{
${ }^{26}$ Gobierno de España. Ministerio de educación, cultura y deporte. Universidades Españolas: https://www.educacion.gob.es/educacion/universidades/educacion-superior-universitaria/queestudiar-donde/universidades-espanolas.html
} 
literatura infantil, porque mi investigación se fundamenta en los cuentos infantiles que se manejan en las aulas y son utilizados como materiales didácticos para el aprendizaje social de los niños y niñas de este periodo. Considero imprescindible que existan asignaturas relacionadas con la literatura infantil para tener un conocimiento general de los materiales didácticos que se emplean en los centros educativos, porque es importante saber qué, cómo y de qué manera transmiten la realidad, revisando dichos materiales para percibir cuando se emplea contenido sexista y desigual en ellos.

\section{- 2.2.1.- El compromiso coeducativo en la formación del profesorado en las universidades españolas.}

Es conveniente que desde la formación del profesorado se insista en la necesidad de la utilización de proyectos coeducativos en educación y en especial desde los primeros años de edad, mostrando materiales didácticos alternativos a los tradicionales que trabajen desde una perspectiva de género en su contenido; por ello la revisión del plan de estudios de la titulación de maestro y maestra en educación infantil, para comprobar el compromiso que tiene el currículum universitario en la formación en dicha etapa, desde una perspectiva de género.

A continuación he elaborado una tabla con todas las universidades del territorio español, pero sólo he obtenido asignaturas relativas a la coeducación y a la literatura infantil en algunas de ellas. He comprobado que 39 universidades de 77 incluyen una serie de materias relacionadas con una educación en igualdad y referentes a la coeducación, por su título y descriptores. Su carácter optativo o básico implica que el compromiso universitario en este asunto atiende a temas relacionados con la igualdad de género y educación no sexista. He procedido a buscar estas asignaturas a través de la 
observación del título de la materia y haciendo referencia a sus descriptores y objetivos, porque los propósitos para su selección han sido comprobar el compromiso de cada universidad española con respeto a la coeducación y la literatura infantil en sus asignaturas. 
- Tabla 1. Universidades españolas revisadas

\begin{tabular}{|c|c|}
\hline \multicolumn{2}{|c|}{ Universidades españolas } \\
\hline A Coruña & Jaume I de Castellón \\
\hline Abat Oliba CEU & La Laguna \\
\hline Alcalá de Henares & La Rioja \\
\hline Alfonso X El Sabio & Las Palmas de Gran Canaria \\
\hline Alicante & León \\
\hline Almería & Lleida \\
\hline Antonio de Nebrija & Málaga \\
\hline Autónoma de Barcelona & Miguel Hernández de Elche \\
\hline Autónoma de Madrid & Mondragón Unibersitatea \\
\hline Barcelona & Murcia \\
\hline Burgos & Nacional de Educación a Distancia(UNED) \\
\hline Cádiz & Navarra \\
\hline Camilo José Cela & Oberta de Catalunya \\
\hline Cantabria & Oviedo \\
\hline Cardenal Herrera-CEU & Pablo de Olavide \\
\hline Carlos III de Madrid & País Vasco/Euskal Herriko Unibertsitatea \\
\hline Castilla-La Mancha & Politécnica de Cartagena \\
\hline Católica de Valencia San Vicente Mártir & Politécnica de Catalunya \\
\hline Católica San Antonio & Politécnica de Madrid \\
\hline Católica Santa Teresa de Jesús de Avila & Politécnica de Valencia \\
\hline Complutense de Madrid & Pompeu Fabra \\
\hline Córdoba & Pontificia Comillas \\
\hline Deusto & Pontificia de Salamanca \\
\hline Europea de Madrid & Pública de Navarra \\
\hline Europea Miguel de Cervantes & Ramón Llull \\
\hline Extremadura & Rey Juan Carlos \\
\hline Francisco de Vitoria & Rovira i Virgili \\
\hline Girona & Salamanca \\
\hline Granada & San Jorge \\
\hline Huelva & San Pablo CEU \\
\hline IE Universidad & Santiago de Compostela \\
\hline Illes Balears & Sevilla \\
\hline Internacional de Andalucía & $\begin{array}{l}\text { Universidad a Distancia de Madrid } \\
\text { (UDIMA) }\end{array}$ \\
\hline Internacional de Catalunya & València-Estudi General \\
\hline Internacional Isabel I de Castilla & Valladolid \\
\hline Internacional Menéndez Pelayo & Vic \\
\hline Internacional de la Rioja & Vigo \\
\hline Internacional Valenciana & Zaragoza \\
\hline Jaén & \\
\hline
\end{tabular}


De entre unas 39 universidades revisadas dentro del marco español, he podido comprobar que no existen asignaturas concretas en materia de coeducación que aparezcan en la mayoría de los planes de estudios de las distintas universidades españolas, tan sólo algunas de ellas hacen mención a valores para una educación en mediación intercultural y diversidad en el aula, pero no es un hecho que refleje algo común en el currículo de cada universidad. Son 20 universidades las que contemplan asignaturas que hacen referencia a los estudios sobre género, identidad sexual, coeducación o aspectos relacionados con ella ${ }^{27}$.

A continuación he elaborado una tabla de estas asignaturas que aparecen en aquellas universidades españolas e incluyen una formación académica en coeducación, con su respectiva universidad, materia, descriptores, curso y carácter. Puesto que algunas asignaturas se imparten en varias universidades, he seleccionado aquellos descriptores de cada universidad que más se acercan a mis propósitos dependiendo éstos del contenido de la materia, en función de si tienen relación o no con la coeducación.

\footnotetext{
${ }^{27}$ Jaén, Almería, Huelva, León, Valladolid, Granada, Córdoba, Málaga, Autónoma de Barcelona, Cádiz, Sevilla, Europea de Madrid, Zaragoza, Salamanca, La Rioja, Badajoz, Alicante, Burgos, Las Palmas de Gran Canaria y Murcia.
} 
- Tabla 2. Tabla de asignaturas revisadas relativas a la coeducación

\begin{tabular}{|c|c|c|c|}
\hline Materia & Universidad & Curso y Carácter & Descriptores \\
\hline $\begin{array}{l}\text { Educación } \\
\text { intercultural }\end{array}$ & $\begin{array}{l}\text { Jaén } \\
\text { Almería } \\
\text { Huelva } \\
\text { León } \\
\text { Valladolid }\end{array}$ & $\begin{array}{l}\text { 3o y 4 Curso } \\
\text { 2o Curso, Optativa } \\
\text { Optativa } \\
\text { 20 Curso, OBL } \\
\text { 4o Curso, Optativa }\end{array}$ & 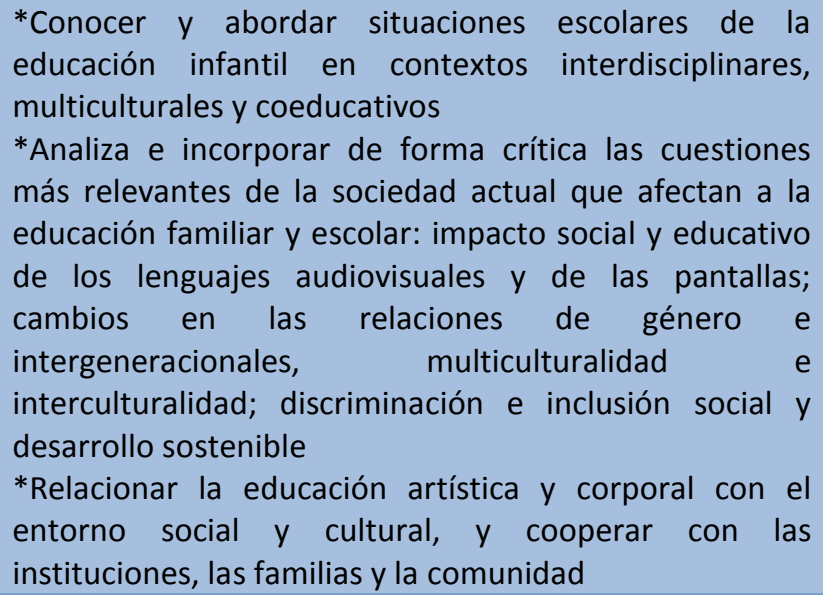 \\
\hline $\begin{array}{l}\text { Educación para } \\
\text { la paz y en } \\
\text { valores en } \\
\text { Educación } \\
\text { Infantil }\end{array}$ & Granada & 4을 Curso, Optativo & $\begin{array}{l}\text { *Conocer los fundamentos teóricos de los valores, la } \\
\text { paz, la igualdad y la sostenibilidad, su naturaleza, sus } \\
\text { múltiples significados, las teorías axiológicas, las } \\
\text { definiciones, sus propiedades, las jerarquías que se } \\
\text { establecen y la crisis de valores, así como promover el } \\
\text { interés por la Cultura de Paz y la Igualdad a través de } \\
\text { proyectos didácticos adecuados } \\
\text { *Promover el interés por los fenómenos sociales } \\
\text { emergentes en el entorno, estableciendo estrategias de } \\
\text { actuación frente a los diferentes problemas sociales }\end{array}$ \\
\hline $\begin{array}{l}\text { Convivencia en } \\
\text { la escuela y } \\
\text { cultura en paz } \\
\text { en Educación } \\
\text { Infantil }\end{array}$ & Córdoba & 20 Curso, OBL & $\begin{array}{l}\text { *Tomar conciencia del amor universal, la no violencia y } \\
\text { de la paz, con el propósito de cooperar al desarrollo de } \\
\text { su personalidad integral en la etapa de educación } \\
\text { infantil } \\
\text { * Procurar un mundo más fraterno, más pacífico y } \\
\text { menos violento en esta etapa educativa }\end{array}$ \\
\hline $\begin{array}{l}\text { Adquisición y } \\
\text { desarrollo de } \\
\text { la identidad } \\
\text { sexual y de } \\
\text { género y } \\
\text { coeducación }\end{array}$ & Córdoba & Optativa & $\begin{array}{l}\text { *Hacer desaparecer en el alumnado la concepción de } \\
\text { los estereotipos femeninos o masculinos aplicados a } \\
\text { cada género } \\
\text { *Conseguir que la convivencia entre niñas y niños se } \\
\text { enriquezca con el beneficio del trabajo en común } \\
\text { propiciando la ayuda y la colaboración en lugar de la } \\
\text { competición } \\
\text { *Favorecer la relación familia-escuela implicándola en } \\
\text { los aprendizajes, intentando conseguir una misma línea } \\
\text { en la promoción de la igualdad de oportunidades para } \\
\text { ambos sexos }\end{array}$ \\
\hline $\begin{array}{c}\text { Educación para } \\
\text { la ciudadanía y } \\
\text { Derechos } \\
\text { Humanos }\end{array}$ & $\begin{array}{l}\text { Málaga } \\
\text { Autónoma } \\
\text { de } \\
\text { Barcelona }\end{array}$ & $\begin{array}{l}\text { 20 Curso, OBL } \\
\text { 4을 Curso, Optativa }\end{array}$ & $\begin{array}{l}\text { *Analizar y valorar la actual concepción de la educación } \\
\text { para una ciudadanía democrática y las razones que } \\
\text { explicar la introducción de la asignatura dentro de la } \\
\text { enseñanza obligatoria } \\
\text { *Caracterizar los criterios para la selección de los } \\
\text { contenidos y de los procedimientos de la educación } \\
\text { para la ciudadanía de la competencia social y ciudadana } \\
\text { y del resto de competencias } \\
\text { *Comprender diferentes enfoques teóricos y prácticas } \\
\text { en torno a la educación para la ciudadanía }\end{array}$ \\
\hline
\end{tabular}




\begin{tabular}{|c|c|c|c|}
\hline $\begin{array}{l}\text { Orientaciones } \\
\text { metodológicas } \\
\text { y } \\
\text { Herramientas } \\
\text { para la } \\
\text { Coeducación }\end{array}$ & $\begin{array}{l}\text { Autónoma } \\
\text { de } \\
\text { Barcelona }\end{array}$ & 4\% Curso, Optativa & $\begin{array}{l}\text { * Ofrecer un acercamiento a la coeducación como } \\
\text { respuesta a la exigencia y la necesidad de una educación } \\
\text { para la igualdad } \\
\text { *Sensibilizar a los equipos docentes de la importancia } \\
\text { de una práctica coeducativa } \\
\text { * Realizar una aproximación teórica sobre los principales } \\
\text { conceptos vinculados con la coeducación en el contexto } \\
\text { educativo actual y a la luz de la Ley Orgánica de } \\
\text { Educación } \\
\text { *Desarrollar pautas para elaborar y llevar a cabo un } \\
\text { proyecto de coeducación en el marco de Proyecto } \\
\text { Educativo de Centro }\end{array}$ \\
\hline $\begin{array}{l}\text { Igualdad de } \\
\text { Género y } \\
\text { Educación }\end{array}$ & Almería & 30 Curso, Optativa & $\begin{array}{l}\text { *Desarrollar competencias profesionales que permitan } \\
\text { la intervención educativa en materia de igualdad y no } \\
\text { discriminación y formar en áreas de Estudios de las } \\
\text { Mujeres y de Género } \\
\text { *Educar en el respeto de los derechos y libertades } \\
\text { fundamentales y de la igualdad entre hombres y } \\
\text { mujeres y en el ejercicio de la tolerancia y la libertad } \\
\text { dentro de los principios democráticos de convivencia } \\
\text { *Educar en la prevención de conflictos y en la resolución } \\
\text { pacífica de los mismos, en todos los ámbitos de la vida } \\
\text { personal, familiar y social } \\
\text { *Detectar la violencia en el ámbito familiar, } \\
\text { especialmente sobre la mujer y los hijos e hijas } \\
\text { *Fomentar las actitudes encaminadas al ejercicio de la } \\
\text { igualdad de derechos y obligaciones por parte de } \\
\text { mujeres y hombres, tanto en el ámbito público como } \\
\text { privado, y la corresponsabilidad entre los mismos en el } \\
\text { ámbito doméstico }\end{array}$ \\
\hline $\begin{array}{l}\text { Atención a la } \\
\text { diversidad en } \\
\text { Educación } \\
\text { Infantil }\end{array}$ & $\begin{array}{c}\text { Cádiz } \\
\text { Granada } \\
\text { Huelva } \\
\text { Europea de } \\
\text { Madrid } \\
\text { Zaragoza } \\
\text { León }\end{array}$ & $\begin{array}{l}\text { 20 Curso, OBL } \\
\text { 2o Curso, } \\
\text { Formación Básica } \\
\text { 20 Curso, OBL } \\
\text { 3o Curso, OBL } \\
\text { 40 Curso, OBL } \\
\text { 2o Curso, } \\
\text { Formación Básica } \\
\text { 20 Curso, OBL } \\
\text { 2o Curso, } \\
\text { Formación Básica }\end{array}$ & $\begin{array}{l}\text { *Conocer cuáles son las líneas de actuación e } \\
\text { investigación actuales relacionadas con el movimiento } \\
\text { de educación en la diversidad } \\
\text { *Conocer distintos modelos de actuación docente } \\
\text { orientados a dar respuestas adecuadas a la diversidad } \\
\text { del alumnado } \\
\text { *Profundizar y fundamentar los conocimientos } \\
\text { generales de planificación y programación didáctica que } \\
\text { habilitan los procesos de adaptación curricular } \\
\text { *Conocer los tipos y niveles de adaptación curricular } \\
\text { *Diseñar procesos de adaptación de enseñanza para } \\
\text { situaciones particulares aplicando distintos modelos, } \\
\text { principios y enfoques de intervención } \\
\text { *Seleccionar y aplicar diseños, técnicas e instrumentos } \\
\text { de atención educativa adecuados a la diversidad del } \\
\text { alumnado } \\
\text { *Utilizar las fuentes documentales y de información } \\
\text { relativas a la atención a la diversidad } \\
\text { *Establecer estrategias organizativas personales, } \\
\text { funcionales y materiales que den respuesta a la } \\
\text { atención educativa a la diversidad } \\
\text { *Ser conscientes de las propias creencias, sentimientos } \\
\text { y valores en relación con la educación en situaciones de } \\
\text { diversidad }\end{array}$ \\
\hline
\end{tabular}




\begin{tabular}{|c|c|c|c|}
\hline $\begin{array}{l}\text { Habilidades } \\
\text { Socioemociona } \\
\text { les y relaciones } \\
\text { entre iguales } \\
\text { en Educación } \\
\text { Infantil }\end{array}$ & Badajoz & Optativa & $\begin{array}{l}\text { *Conseguir situaciones estables, calmadas, relajadas } \\
\text { *Buscar relaciones personales próximas y afectuosas } \\
\text { con los niños, especialmente con los más nerviosos y } \\
\text { necesitados de atención } \\
\text { *Prodigar refuerzos positivos de manera constante y } \\
\text { con todos los niños } \\
\text { *Evitar cualquier tipo de rebajamiento: poner en } \\
\text { evidencia pública, avergonzar ridiculizar, echar la culpa } \\
\text { *Usar siempre propuestas, sugerencias, instrucciones } \\
\text { positivas en lugar de indicar lo que no hay que hacer }\end{array}$ \\
\hline $\begin{array}{l}\text { Diversidad y } \\
\text { Coeducación }\end{array}$ & Sevilla & $\begin{array}{l}\text { 20 Curso, } \\
\text { Formación Básica }\end{array}$ & $\begin{array}{l}\text { *Conocer, comprender y valorar la riqueza que aporta } \\
\text { al grupo humano la diversidad derivada de la diferencia } \\
\text { sexual } \\
\text { *Sensibilizar, informar y formar al futuro profesorado de } \\
\text { Educación Infantil sobre la necesidad de respetar y } \\
\text { cultivar el principio de igualdad de oportunidades } \\
\text { educativas entre mujeres y hombres } \\
\text { *Captar los principales mecanismos de construcción de } \\
\text { identidades de género en la infancia } \\
\text { *Conocer la evolución histórica y legislativa del } \\
\text { tratamiento de la diferencia sexual en la escuela } \\
\text { *Identificar y analizar críticamente las principales } \\
\text { formas de transmisión de estereotipos sexuales en } \\
\text { espacios educativos formales, no formales e informales } \\
\text { *Diseñar estrategias de intervención y acciones } \\
\text { positivas que faciliten trabajar en las aulas de infantil en } \\
\text { la valoración de las diferencias } \\
\text { *Contactar con personas, instituciones y materiales } \\
\text { específicos para dicha tarea con buenas prácticas } \\
\text { *Y, sobre todo, general un compromiso ético-político de } \\
\text { implicación en la transformación social }\end{array}$ \\
\hline $\begin{array}{c}\text { Filosofía para } \\
\text { niños: Aprende } \\
\text { a ser }\end{array}$ & Sevilla & 3 Curso, Optativa & $\begin{array}{l}\text { *Desarrollar las habilidades de razonamiento filosófico y } \\
\text { su implicación en cuestiones de trascendencia personal } \\
\text { *Dar la posibilidad y las condiciones para que la } \\
\text { sabiduría propia de cada persona salga a la luz desde las } \\
\text { profundidades del espíritu } \\
\text { *Propiciar el espacio para pensar, elegir y actuar } \\
\text { mediante el mejor uso de la razón y la emotividad }\end{array}$ \\
\hline $\begin{array}{l}\text { Educar en } \\
\text { Igualdad de } \\
\text { Género }\end{array}$ & Alicante & 4ㅇ Curso, Optativa & $\begin{array}{l}\text { *Educar en igualdad desde la escuela } \\
\text { *Prevenir la violencia de género, favoreciendo } \\
\text { relaciones en equidad } \\
\text { *Utilizar el sentido de cooperación y colaboración } \\
\text { dentro y fuera del aula; prestando especial atención al } \\
\text { seno familiar } \\
\text { *Tratar de crear un ambiente y clima distendido, en las } \\
\text { relaciones personales, favoreciendo la comunicación } \\
\text { interpersonal y la aceptación de las diferencias } \\
\text { mediante situaciones que permitan el diálogo } \\
\text { *Fomentar la participación del alumno en la } \\
\text { organización y el desarrollo de las tareas que serán } \\
\text { llevadas a cabo en clase; así como aquéllas que les sean } \\
\text { propuestas en casa } \\
\text { *Fomentar la autonomía del alumnado, tanto en casa } \\
\text { como en el entorno escolar, de modo que sean capaces } \\
\text { de realizar tareas cotidianas, evitando desigualdades } \\
\text { *Potenciar la colaboración familia-escuela en la }\end{array}$ \\
\hline
\end{tabular}




\begin{tabular}{|c|c|c|c|}
\hline & & & educación para la igualdad de niños y niñas \\
\hline $\begin{array}{l}\text { Sociología de } \\
\text { las relaciones } \\
\text { de género y de } \\
\text { la familia }\end{array}$ & Badajoz & $\begin{array}{l}\text { 1o Curso, } \\
\text { Formación Básica }\end{array}$ & $\begin{array}{l}\text { * Comprender el carácter evolutivo y la pluralidad de las } \\
\text { sociedades actuales y desarrollar actitudes de respeto, } \\
\text { tolerancia y solidaridad hacia los diferentes grupos } \\
\text { sociales } \\
\text { * Ser conscientes del derecho a la igualdad de trato y de } \\
\text { oportunidades entre mujeres y hombres y aplicar } \\
\text { medidas que eliminan los obstáculos que dificultan la } \\
\text { igualdad efectiva entre mujeres y hombres y fomenten } \\
\text { la igualdad entre unas y otros } \\
\text { * Reflexionar de forma crítica y lógica sobre la necesidad } \\
\text { de eliminar toda forma de discriminación, directa o } \\
\text { indirecta, en particular, la discriminación racial, la } \\
\text { discriminación contra la mujer, la derivada de la } \\
\text { orientación sexual o la causada por una discapacidad } \\
\text { *Diseñar y regular espacios de aprendizaje en contexto } \\
\text { de diversidad que atiendan a la igualdad de género, a la } \\
\text { equidad y al respeto a los derechos humanos que } \\
\text { conformen los valores de la formación ciudadana } \\
\text { *Analizar e incorporar de forma crítica las cuestiones } \\
\text { más relevantes de la sociedad actual que afectan a la } \\
\text { educación familiar y escolar, cambios en las relaciones } \\
\text { de género intergeneracionales, discriminación e } \\
\text { inclusión social } \\
\text { * Conocer la evolución histórica de la familia, los } \\
\text { diferentes tipos de familia, estilos de vida y educación } \\
\text { en el contexto familiar }\end{array}$ \\
\hline $\begin{array}{l}\text { Educación para } \\
\text { la Paz y la } \\
\text { Igualdad }\end{array}$ & $\begin{array}{l}\text { Burgos } \\
\text { Valladolid }\end{array}$ & $\begin{array}{c}\text { 2ºurso, Formación } \\
\text { Básica } \\
\text { 1o Curso, OBL }\end{array}$ & $\begin{array}{l}\text { *Tener la capacidad de reunir e interpretar datos } \\
\text { relevantes sobre la educación infantil para emitir juicios } \\
\text { que incluyan una reflexión sobre temas relevantes de } \\
\text { índole social o ética } \\
\text { * Responsabilizarse de la propia formación y del papel } \\
\text { de la profesión en la sociedad } \\
\text { *Adquirir conocimientos sobre al evolución del } \\
\text { pensamiento, las costumbres, las creencias y los } \\
\text { movimientos sociales y políticos a lo largo de la historia } \\
\text { *Conocer otras culturas y costumbres } \\
\text { *Conocer los factores que intervienen en las relaciones } \\
\text { sociales y los diferentes tipos de relación que pueden } \\
\text { establecerse } \\
\text { * Resolver problemas en las relaciones interpersonales y } \\
\text { adaptarse a nuevas situaciones } \\
\text { *Estar comprometido con el fomento de valores } \\
\text { democráticos, con especial incidencia en los de } \\
\text { tolerancia, solidaridad, igualdad, justicia y no violencia } \\
\text { *Conocer la dimensión pedagógica de la interacción con } \\
\text { los iguales y los adultos y saber promover la } \\
\text { participación en actividades colectivas, el trabajo } \\
\text { cooperativo y el esfuerzo individual }\end{array}$ \\
\hline $\begin{array}{l}\text { Didáctica de la } \\
\text { educación } \\
\text { afectivo sexual }\end{array}$ & $\begin{array}{l}\text { Las Palmas } \\
\text { de Gran } \\
\text { Canaria }\end{array}$ & Optativa & $\begin{array}{l}\text { *Conocer y comprender el desarrollo afectivo y sexual } \\
\text { de los niños y niñas de } 0 \text { a } 6 \text { años } \\
\text { *Promover la educación en valores, actitudes y hábitos }\end{array}$ \\
\hline
\end{tabular}




\begin{tabular}{|c|c|c|c|}
\hline & & & $\begin{array}{l}\text { para el cuidado de sí mismos y la adecuada convivencia } \\
\text { *Contribuir a transmitir seguridad, tranquilidad y afecto } \\
\text { valorando sus estados de ánimo como factor que } \\
\text { contribuye al proceso armónico e integral de los niños y } \\
\text { niñas. } \\
\text { *Conocer los procesos de interacción y comunicación en } \\
\text { el aula y fuera de ella, para saber detectar y actuar con } \\
\text { eficacia en la resolución de problemas afectivos y } \\
\text { sexuales de su alumnado } \\
\text { *Acercarnos a la realidad de los niños y sus familias, } \\
\text { conociendo, aceptando e integrando los diferentes } \\
\text { tipos, incidiendo en las mejores del proceso educativo } \\
\text { *Aceptar la inclusión educativa de todas las diversidades } \\
\text { sexuales } \\
\text { *Saber responder adecuadamente a las necesidades, los } \\
\text { intereses y curiosidades afectivas y sexuales de los niños } \\
\text { y niñas } \\
\text { *Saber detectar y actuar con eficacia en la resolución de } \\
\text { problemas afectivos y sexuales del alumnado } \\
\text { *Aplicar los conocimientos teóricos sobre sexualidad y } \\
\text { educación afectivo-sexual para el desarrollo de una } \\
\text { clase en un centro educativo } \\
\text { *Concebir y tratar el cuerpo de forma global, } \\
\text { desarrollando la vivencia sana, de cuidado, respeto, } \\
\text { disfrute, placer y comunicación que establecemos con él }\end{array}$ \\
\hline $\begin{array}{l}\text { Interdisciplinar } \\
\text { iedad en la } \\
\text { Educación } \\
\text { infantil }\end{array}$ & La Rioja & 4ㅇ Curso, OBL & $\begin{array}{l}\text { *Contemplar la realidad física, social y natural desde } \\
\text { todas sus dimensiones } \\
\text { *Acercamiento multidimensional e integrado } \\
\text { (interdisciplinar), donde todas las áreas sean } \\
\text { consideradas y las relaciones entre las mismas amplíen } \\
\text { la información sobre el objetivo de conocimiento } \\
\text { * Ofrecer una visión profunda de los diversos enfoques } \\
\text { globalizadores y una aproximación a la noción de } \\
\text { interdisciplinariedad como el acercamiento pedagógico } \\
\text { que permite considerar la enseñanza de la realidad } \\
\text { física, social y natural como un todo, al mismo tiempo, } \\
\text { único y complejo, fragmentado y sencillo }\end{array}$ \\
\hline $\begin{array}{c}\text { Sociología del } \\
\text { Género }\end{array}$ & Murcia & 4을 Curso, Optativa & $\begin{array}{l}\text { *Diseñar y regular procesos de aprendizaje en contextos } \\
\text { de diversidad que atiendan a las singulares necesidades } \\
\text { educativas de los estudiantes, a la igualdad de género, a } \\
\text { la equidad y al respeto de los derechos humanos } \\
\text { *Fomentar la convivencia en el aula y fuera de ella y } \\
\text { abordar la resolución pacífica de conflictos desde el } \\
\text { diálogo. Saber observar sistemáticamente contextos de } \\
\text { aprendizaje y convivencia y saber reflexionar sobre ellos } \\
\text { *Comprender la organización y dinámica interna de los } \\
\text { centros educativos de educación infantil y reflexionar } \\
\text { sobre sus funciones socio-pedagógicas } \\
\text { *Aprender a aprender como formación para toda la } \\
\text { vida: asumir que el ejercicio de la función docente ha de } \\
\text { ir perfeccionándose y adaptándose a los cambios } \\
\text { científicos, pedagógicos y sociales; reflexionar sobre las } \\
\text { prácticas del aula para innovar y mejorar la propia } \\
\text { práctica docente } \\
\text { * Reflexionar sobre las prácticas de aula para innovar y } \\
\text { mejorar la labor docente. Adquirir hábitos y destrezas }\end{array}$ \\
\hline
\end{tabular}


de indagación

* Orientar y valorar con los padres y madres en la educación familiar y dominar estrategias organizativas y habilidades de mediación útiles para una adecuada relación con las familias de los alumnos

Fuente: Elaboración Propia

El análisis que pretendo hacer sobre esta información va a configurarse en torno a la definición de la asignatura, los descriptores que de ella se desarrollan, su carácter optativo o básico y la cantidad de asignaturas para comprobar el compromiso de la universidad que las imparte.

Todas estas asignaturas mantienen una relación entre el nombre de la materia con el desarrollo de sus descriptores, puesto que a simple vista podemos derivar una determinada información al leer el título de la asignatura y cuando te diriges al descriptor existe un hilo conductor entre ambos. Por ejemplo, en la asignatura de Orientaciones Metodológicas y Herramientas para la Coeducación, ya se entrevé cuales son las cuestiones que van a tratarse en sus descriptores, en este caso, acerca de las propuestas coeducativas para impartir una educación en igualdad dentro del aula, o cuando la materia en su título hace referencia a estudios de género e igualdad y sus descriptores hacen referencia a estudios de género, al fomento de la autonomía personal y a favorecer relaciones de equidad.

La mayoría de los descriptores de las asignaturas nos acercan al contenido de la materia que se imparte, dejando ver los puntos básicos y relevantes que toman en consideración para el desarrollo de éstas. Puesto que son varias las universidades que imparten algunas de dichas asignaturas, he seleccionado aquellos descriptores de dicha materia con su respectiva universidad, que más se acerquen a mis propósitos de investigación, siendo éstos, los que además de tener relación con el título de la 
asignatura a la que pertenecen, trabajan a su vez cuestiones relacionadas con la Coeducación.

Lo más llamativo de la mayoría de estas asignaturas es que se ofertan como materias optativas, no como obligatorias, dando la opción al alumnado de elegir libremente si cursarlas o no, cuando considero que son relevantes para cualquier tipo de estudio, pero más concretamente para trabajar con niños y niñas en la etapa de educación infantil. También he comprobado cómo algunas asignaturas que están orientadas a estudiar propuestas coeducativas o de género sólo se cursan en una o dos universidades del marco español, dejando ver cómo estas materias además de no ejercerse con transversalidad, son de poco interés para impartirlas en esta titulación.

Esto ocurre porque, me parece a mí, de la posición de poder que tenga un departamento o personas encargadas de la elección y aprobación de tales asignaturas, dejando ver el compromiso que tiene dicha universidad con temas relacionados con la igualdad de género o relativas a la coeducación y la concienciación con respecto a cuestiones que están en auge actualmente y se trabajan para fomentar y mejorar el aprendizaje del profesorado encargado de la docencia de niños y niñas.

También considero importante elaborar otra tabla de aquellas asignaturas que trabajan con respecto a la literatura infantil y al aprendizaje de las lenguas y lectoescrituras dentro de un contexto coeducativo y no sexista, también con su respectiva universidad, materia, descriptores, curso y carácter. 
- Tabla 3. Tabla de asignaturas revisadas relativas a la literatura infantil y relacionadas con el aprendizaje de las lenguas y lectoescrituras

\begin{tabular}{|c|c|c|c|}
\hline Materia & Universidad & Curso y Carácter & Descriptores \\
\hline $\begin{array}{l}\text { Literatura } \\
\text { infantil }\end{array}$ & $\begin{array}{l}\text { Jaén } \\
\text { Córdoba } \\
\text { Málaga } \\
\text { Almería } \\
\text { Sevilla } \\
\text { Granada } \\
\text { Huelva } \\
\text { Complutense } \\
\text { de Madrid } \\
\text { Nebrija } \\
\text { Alcalá de } \\
\text { Henares } \\
\text { Barcelona } \\
\text { Vic } \\
\text { Autónoma de } \\
\text { Barcelona } \\
\text { Zaragoza } \\
\text { Alicante } \\
\text { Internacional } \\
\text { de Valencia } \\
\text { Badajoz } \\
\text { A Coruña } \\
\text { Vigo } \\
\text { Cantabria } \\
\text { Navarra } \\
\text { Valladolid } \\
\text { Salamanca } \\
\text { Las Palmas de } \\
\text { Gran Canaria } \\
\text { Mallorca } \\
\text { La Rioja }\end{array}$ & 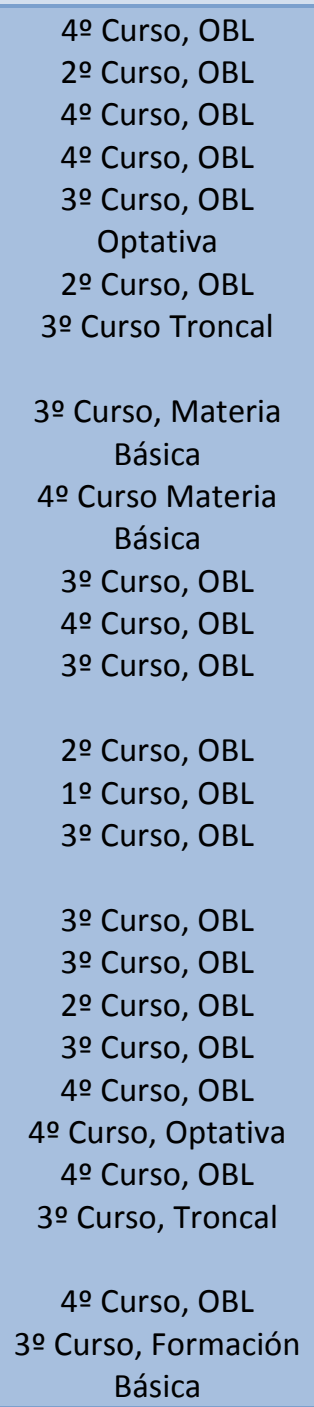 & $\begin{array}{l}\text { *Formación literaria y conocimiento de la } \\
\text { literatura infantil. Concepto y límites de la } \\
\text { literatura } \\
\text { *Los géneros en la literatura infantil: } \\
\text { narrativa, poesía y teatro } \\
\text { *Leer antes de leer: los álbumes infantiles } \\
\text { *Teatro infantil y juego dramático } \\
\text { *La literatura infantil en el aula } \\
\text { *Actividades y proyectos de animación y } \\
\text { promoción a la lectura }\end{array}$ \\
\hline $\begin{array}{c}\text { Taller de } \\
\text { recitado, } \\
\text { cuentacuentos y } \\
\text { dramatización }\end{array}$ & Huelva & Optativa & $\begin{array}{l}\text { *Analizar las posibilidades para la práctica } \\
\text { de la dramatización en el marco cotidiano } \\
\text { de la escuela } \\
\text { *Conocer diversas actividades técnicas y } \\
\text { estrategias para acercar al niño al hecho } \\
\text { teatral, estimular su imaginación y } \\
\text { desarrollar su espontaneidad, sus } \\
\text { posibilidades de traducción gestual y su } \\
\text { facultad de improvisación } \\
\text { *Desarrollar el sentido crítico personal } \\
\text { ante las creaciones dramáticas dirigidas a } \\
\text { la infancia y a la juventud } \\
\text { * Ofrecer recursos para desarrollar en el } \\
\text { niño el sentido del trabajo colectivo, la } \\
\text { apertura hacia los demás y el respeto a } \\
\text { sus creaciones y trabajos } \\
\text { *Fomentar el conocimiento de obras y } \\
\text { adaptaciones dramáticas mediante la }\end{array}$ \\
\hline
\end{tabular}




\begin{tabular}{|c|c|c|c|}
\hline & & & puesta en escena de las mismas \\
\hline Lectoescritura & $\begin{array}{l}\text { Europea de } \\
\text { Madrid } \\
\text { Lleida } \\
\text { Internacional } \\
\text { de Cataluña } \\
\text { Gerona } \\
\text { Alicante } \\
\text { Internacional } \\
\text { de Valencia } \\
\text { Navarra } \\
\text { Oviedo } \\
\text { Cuenca } \\
\text { Burgos } \\
\text { Valladolid } \\
\text { La Rioja } \\
\text { Murcia }\end{array}$ & $\begin{array}{c}\text { 2 Curso, OBL } \\
\text { 1,2 y } 3 \text { o Curso, OBL } \\
\text { 3 Curso, OBL } \\
\text { 2 Curso, OBL } \\
\text { 20 Curso, Formación } \\
\text { Básica } \\
\text { 1 Curso, OBL } \\
\text { 4 Curso, OBL } \\
\text { 2 Curso, OBL } \\
\text { 2 Curso, OBL } \\
\text { 1 Curso, Formación } \\
\text { Básica } \\
\text { 2 Curso, OBL } \\
\text { Optativa } \\
\text { 3 Curso, OBL }\end{array}$ & $\begin{array}{l}\text { *Conocer la trayectoria histórica de las } \\
\text { teorías de la adquisición del lenguaje en } \\
\text { las edades 0-3 y } 3-6 \\
\text { *Conocer la trayectoria histórica de la } \\
\text { adquisición inicial de la lectoescritura } \\
\text { *Conocer los procesos cognitivos y } \\
\text { metacognitivos de la adquisición del } \\
\text { lenguaje } \\
\text { *Conocer los procesos cognitivos y } \\
\text { metacognitivos implicados en la lectura y } \\
\text { la escritura iniciales } \\
\text { *Analizar la base cognitiva de las } \\
\text { capacidades comunicativas que pretende } \\
\text { desarrollar el currículo } \\
\text { *Conocer las condiciones que pueden } \\
\text { favorecer a estas capacidades }\end{array}$ \\
\hline Cuentos y Poesía & $\begin{array}{l}\text { Complutense } \\
\text { de Madrid }\end{array}$ & Optativa & $\begin{array}{l}\text { * Leer y valorar cuentos y poesías tanto de } \\
\text { tradición oral como de autor } \\
\text { *Aprender recursos didácticos aplicables a } \\
\text { la poesía y al cuento para el aula de } \\
\text { Educación Infantil } \\
\text { *Conocer los rasgos de la poesía y del } \\
\text { cuento dentro de los géneros literarios } \\
\text { *Situar en la evolución de la Literatura } \\
\text { Infantil los cuentos y poemas utilizados en } \\
\text { la asignatura } \\
\text { *Desarrollar recursos didácticos aplicables } \\
\text { a la poesía y al cuento para el aula de } \\
\text { Educación infantil }\end{array}$ \\
\hline $\begin{array}{l}\text { Didáctica de la } \\
\text { Narrativa y de la } \\
\text { Poesía Infantil }\end{array}$ & $\begin{array}{c}\text { Autónoma de } \\
\text { Barcelona } \\
\text { Murcia }\end{array}$ & $\begin{array}{l}\text { 40 Curso, Optativa } \\
\text { 4ㅇ Curso, Optativa }\end{array}$ & $\begin{array}{l}\text { * La asignatura Narrativa y poesía en la } \\
\text { Educación Infantil se propone profundizar } \\
\text { en el conocimiento y el uso de la literatura } \\
\text { para niños desde los primeros meses } \\
\text { hasta que saben leer autónomamente } \\
\text { * La Educación Infantil se propone } \\
\text { profundizar en el conocimiento y el uso de } \\
\text { la literatura para niños desde los primeros } \\
\text { meses hasta que saben leer } \\
\text { autónomamente } \\
\text { * La asignatura se centra especialmente en } \\
\text { el desarrollo de las habilidades de } \\
\text { dinamización del material literario y } \\
\text { ficcional (uso de juegos lingüísticos, } \\
\text { narración oral, presentaciones visuales, } \\
\text { actividades para la expresión de los niños, } \\
\text { confecciones de relatos, etcétera) } \\
\text { *Se parte de criterios de valoración de los } \\
\text { diferentes tipos de libros y literatura en } \\
\text { los diferentes formatos y soportes, } \\
\text { impresos y en pantalla, para pasar a } \\
\text { ofrecer un taller práctico de diseño de } \\
\text { actividades según diferentes objetivos } \\
\text { educativos y con diversas técnicas de }\end{array}$ \\
\hline
\end{tabular}




\begin{tabular}{|c|c|c|c|}
\hline & & & $\begin{array}{l}\text { realización } \\
\text { *Se propone la familiarización con un } \\
\text { amplio panorama de recursos } \\
\text { bibliográficos y digitales, tanto de la } \\
\text { producción para niños, como de fuentes } \\
\text { de apoyo para las actividades, que resulte } \\
\text { útil para la tarea profesional de los } \\
\text { maestros }\end{array}$ \\
\hline $\begin{array}{l}\text { Literatura } \\
\text { Popular } \\
\text { Castellana }\end{array}$ & Alicante & Optativa & $\begin{array}{l}\text { *Introducir la Literatura oral en el ámbito } \\
\text { educativo } \\
\text { *Conocer nuevas líneas de investigación } \\
\text { para la didáctica de la lengua y la } \\
\text { literatura en su conexión con la literatura } \\
\text { oral } \\
\text { * Reflexionar sobre el concepto de } \\
\text { Literatura popular castellana de tradición } \\
\text { oral y apreciar sus valores en la educación } \\
\text { lingüística y literaria de los alumnos de } \\
\text { Educación infantil } \\
\text { *Comprender y potenciar entre los } \\
\text { alumnos la capacidad de recepción y de } \\
\text { reproducción de textos orales y de } \\
\text { técnicas de expresión oral } \\
\text { *Conocer el uso de juegos, canciones, } \\
\text { adivinanzas, cuentos y demás géneros de } \\
\text { la Literatura popular, como recursos } \\
\text { metodológicos para conseguir el objetivo } \\
\text { intercultural y globalizador }\end{array}$ \\
\hline $\begin{array}{l}\text { Formación } \\
\text { Literaria para } \\
\text { maestros }\end{array}$ & $\begin{array}{c}\text { Católica de } \\
\text { Valencia }\end{array}$ & 3ㅇ Curso, OBL & $\begin{array}{l}\text { *Conocer la extensión y significado } \\
\text { diacrónico de la denominada Literatura } \\
\text { infantil } \\
\text { *Situar y subrayar el perfil literario de } \\
\text { aquellos autores y títulos que han } \\
\text { traspasado épocas y fronteras en el } \\
\text { entorno infantil-juvenil y el imaginario } \\
\text { colectivo } \\
\text { *Delimitar los géneros y tendencias } \\
\text { desarrollados a lo largo del tiempo } \\
\text { *Desarrollar actitudes de curiosidad e } \\
\text { interés hacia todo tipo de manifestaciones } \\
\text { literarias, particularmente las más } \\
\text { cercanas al entorno sociocultural } \\
\text { valenciano la } \\
\text { *Considerar la importancia de la } \\
\text { biblioteca y tanto de aula de centro, sus } \\
\text { fondos y funcionamiento, en la } \\
\text { adquisición y valoración del acto lector, la } \\
\text { recepción y producción de textos literarios } \\
\text { *Conocer y aprovechar las TIC al servicio } \\
\text { de la Literatura infantil } \\
\text { *Inducir las extraordinarias posibilidades } \\
\text { de disfrute que regala el texto literario, y } \\
\text { colectivamente, así como las sólidas } \\
\text { escalas de valores que puede ayudar a } \\
\text { configurar entre el alumnado de } 0 \text { a } 6 \\
\text { años }\end{array}$ \\
\hline
\end{tabular}




\begin{tabular}{|c|c|c|c|}
\hline $\begin{array}{l}\text { El cuento como } \\
\text { herramienta de } \\
\text { dramatización en } \\
\text { la etapa de } \\
\text { infantil }\end{array}$ & $\begin{array}{c}\text { Católica de } \\
\text { Valencia }\end{array}$ & Optativa & $\begin{array}{l}\text { *El cuento motor es un eslabón previo al } \\
\text { cuento escrito, y puede ir paralelo al } \\
\text { cuento narrado } \\
\text { *El cuento motor incide directamente en } \\
\text { la capacidad expresiva de los niños y niñas } \\
\text { *El niño y niña, cuando ejecuta el cuento } \\
\text { motor, se convierte en protagonista } \\
\text { absoluto } \\
\text { *El cuento motor es una fuente } \\
\text { motivadora que despierta en los niños y } \\
\text { niñas el interés por descubrir historias y } \\
\text { personajes, y les ayuda a introducirse en } \\
\text { los caminos sorprendentes de los libros, } \\
\text { del teatro y compara con otras formas de } \\
\text { entretenimiento menos participativas }\end{array}$ \\
\hline $\begin{array}{c}\text { Literatura } \\
\text { Infantil y el } \\
\text { fomento de la } \\
\text { lectura }\end{array}$ & $\begin{array}{l}\text { Badajoz } \\
\text { Cuenca } \\
\text { Albacete } \\
\text { Toledo } \\
\text { Ciudad Real } \\
\text { Burgos }\end{array}$ & $\begin{array}{c}\text { Optativa } \\
\text { 4o Curso, OBL } \\
\text { 4o Cursos, OBL } \\
\text { 4ㅇ Curso, OBL } \\
\text { 4ㅇ Curso, OBL } \\
\text { 4ㅇ Curso, OBL }\end{array}$ & $\begin{array}{l}\text { *La enseñanza de la lengua en la } \\
\text { educación infantil } \\
\text { *El proceso de adquisición de la lengua } \\
\text { materna } \\
\text { *El perfeccionamiento lectoescritor; } \\
\text { preparación y métodos de enseñanza } \\
\text { *Recursos y animación a la lectura y } \\
\text { escritura en educación infantil } \\
\text { *Conceptos de Literatura, Literatura } \\
\text { infantil y Didáctica de la literatura } \\
\text { *Evolución histórica de la literatura } \\
\text { infantil universal } \\
\text { *La animación a la lectura } \\
\text { *La biblioteca escolar } \\
\text { *Los medios audiovisuales y de } \\
\text { comunicación y la educación literaria } \\
\text { *Teorías de aprendizaje y adquisición de } \\
\text { una segunda enseñanza-aprendizaje de } \\
\text { una lengua extranjera en el aula de } \\
\text { infantil }\end{array}$ \\
\hline $\begin{array}{l}\text { Dibujo infantil y } \\
\text { Expresión } \\
\text { artística }\end{array}$ & $\begin{array}{l}\text { Jaén } \\
\text { Córdoba } \\
\text { Granada } \\
\text { Almería } \\
\text { Huelva } \\
\text { Málaga } \\
\text { Alfonso X El } \\
\text { Sabio } \\
\text { Zaragoza } \\
\text { Católica de } \\
\text { Valencia } \\
\text { Badajoz } \\
\text { Vigo } \\
\text { Cantabria } \\
\text { Cuenca } \\
\text { Burgos } \\
\text { León } \\
\text { Valladolid } \\
\text { Salamanca } \\
\text { Las Palmas de } \\
\text { Gran Canaria }\end{array}$ & 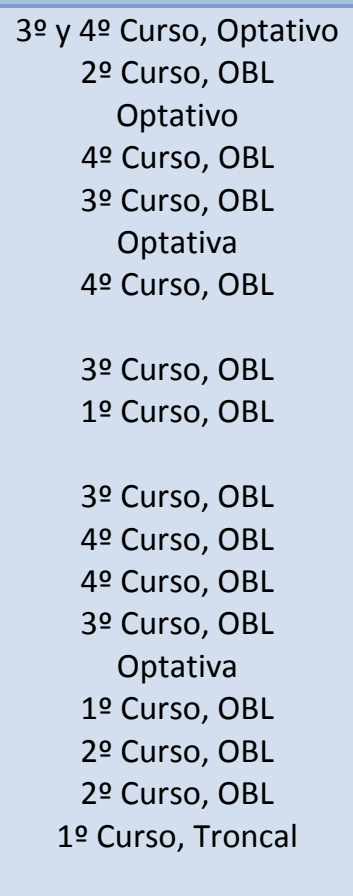 & $\begin{array}{l}\text { *Analizar e incorporar de forma crítica las } \\
\text { cuestiones más relevantes de la sociedad } \\
\text { actual que afectan a la educación familiar } \\
\text { y escolar: impacto social y educativo de } \\
\text { los lenguajes audiovisuales y de las } \\
\text { pantallas; cambios en las relaciones de } \\
\text { género e intergeneracionales; } \\
\text { multiculturalidad e interculturalidad; } \\
\text { discriminación e inclusión social y } \\
\text { desarrollo sostenible } \\
\text { *Tener experiencias de actividades físicas } \\
\text { y artístico creativas adaptadas para la } \\
\text { atención a la diversidad del alumnado y su } \\
\text { integración educativa } \\
\text { *La asignatura tendrá como línea } \\
\text { fundamental la atención a la diversidad } \\
\text { desde las artísticas y físicas como punto } \\
\text { de partida para la integración educativa } \\
\text { *La atención a la diversidad en el sistema } \\
\text { educativo desde las artes y la actividad } \\
\text { física }\end{array}$ \\
\hline
\end{tabular}




\begin{tabular}{|c|c|c|c|}
\hline & $\begin{array}{l}\text { Mallorca } \\
\text { La Rioja }\end{array}$ & $\begin{array}{c}\text { 20 Curso, OBL } \\
\text { Optativa }\end{array}$ & $\begin{array}{l}\text { *Perspectivas y estrategias en ámbitos } \\
\text { específicos: Dificultades sensoriales, } \\
\text { trastornos musculares y motóricos: } \\
\text { diferencias intelectuales, cognitivas y del } \\
\text { aprendizaje; problemas psicólogos y } \\
\text { psicriáticos; trastornos graves del } \\
\text { desarrollo; enfermedades crónicos o de } \\
\text { larga duración; inter y multiculturalismo y } \\
\text { marginación social } \\
\text { *La integración educativa desde el marco } \\
\text { de las artes y la actividad física: } \\
\text { estrategias organizativas, curriculares y } \\
\text { profesionales }\end{array}$ \\
\hline $\begin{array}{l}\text { Educación de } \\
\text { adultos }\end{array}$ & $\begin{array}{l}\text { Las Palmas de } \\
\text { Gran Canaria }\end{array}$ & 10 Curso, Optativa & $\begin{array}{l}\text { *Adquirir los conceptos básicos con el } \\
\text { ámbito de la disciplina } \\
\text { *Conocer la trayectoria y situación actual } \\
\text { de la educación de las personas adultas } \\
\text { *Analizar los problemas más relevantes } \\
\text { relacionados con la educación de las } \\
\text { personas adultas } \\
\text { *Valorar la importancia personal y social } \\
\text { que representa la educación de las } \\
\text { personas adultas } \\
\text { *Proyectar lo aprendido en el análisis de } \\
\text { textos relacionados con el contenido de la } \\
\text { materia }\end{array}$ \\
\hline $\begin{array}{c}\text { Valores de la } \\
\text { imagen y de la } \\
\text { narrativa } \\
\text { audiovisual }\end{array}$ & Jaén & 3 y 4 ㅇ Curso, Optativa & $\begin{array}{l}\text { *Marco general para una pedagogía de la } \\
\text { imagen y la cultura visual: La imagen en la } \\
\text { sociedad actual } \\
\text { *La imagen como medio de comunicación } \\
\text { y expresión } \\
\text { *El estudio analítico de la imagen y la } \\
\text { cultura audiovisual } \\
\text { *La imagen como medio didáctico } \\
\text { *Marco axiológico y narrativo para el } \\
\text { estudio de la cultura visual } \\
\text { contemporánea: los valores educativos } \\
\text { del arte actual y el patrimonio artístico; } \\
\text { del diseño y la artesanía; de los medios de } \\
\text { comunicación de masas (prensa, cine, } \\
\text { publicidad); de las artes escénicas y el } \\
\text { espectáculo promecto y } \\
\text { *La imagen visual como proyecto } \\
\text { proceso narrativo: aplicaciones formativas } \\
\text { en contextos formales y no formales de } \\
\text { educación }\end{array}$ \\
\hline $\begin{array}{l}\text { Función poética } \\
\text { y expresión } \\
\text { teatral en el } \\
\text { desarrollo del } \\
\text { lenguaje infantil }\end{array}$ & Granada & 4ㅇ Curso, Optativa & $\begin{array}{l}\text { *Facilitar el desarrollo activo y pasivo de } \\
\text { vocablos nuevos para que el alumno los } \\
\text { convierta en el léxico propio } \\
\text { *Estimular y practicar la expresión libre y } \\
\text { abierta con la palabra y el cuerpo }\end{array}$ \\
\hline
\end{tabular}




\begin{tabular}{|c|c|c|c|}
\hline $\begin{array}{l}\text { Las artes visuales } \\
\text { en la infancia }\end{array}$ & Granada & 2ㅇ Curso, OBL & $\begin{array}{l}\text { *Funciones y elementos del lenguaje } \\
\text { *Función poética y tipología textual: } \\
\text { narración, descripción, textos dialógicas } \\
\text { *Poesía y canción: El taller de poesía } \\
\text { *Cuento y relato corto } \\
\text { *Teatro infantil y teatro escolar } \\
\text { *La expresión poética y su didáctica } \\
\text { *Taller de dramatización } \\
\text { *Las artes, las culturas visuales y los } \\
\text { mundos virtuales en las sociedades del } \\
\text { siglo XXI } \\
\text { *Los productos visuales para la infancia: } \\
\text { cine de animación y programación infantil } \\
\text { en televisión, la ilustración infantil, los } \\
\text { videojuegos y los juguetes, los parques } \\
\text { temáticos y las golosinas } \\
\text { *Desarrollo del dibujo espontáneo infantil } \\
\text { de } 1 \text { a } 6 \text { años de edad } \\
\text { *La información de consumidores/as de } \\
\text { imágenes visuales durante la infancia } \\
\text { *Aprendizaje artístico y creatividad en la } \\
\text { infancia } \\
\text { *La deriva de los modelos educativos en } \\
\text { artes visuales para la infancia desde } \\
\text { Pestalozzi y Froebel hasta Reggio Emilia y } \\
\text { el proyecto "Espectrum" }\end{array}$ \\
\hline
\end{tabular}

Fuente: Elaboración Propia

El análisis que se deriva de dicha información va a constar de las mismas partes que el apartado anterior; por tanto si nos fijamos en la definición de las asignaturas encontramos que existe una relación entre el título de la materia con el significado de sus descriptores; el título nos acerca a lo que posteriormente los descriptores desarrollan en su contenido, haciendo hincapié sobre todo en la importancia de la lectura y la escritura en la etapa de educación infantil, por ejemplo la asignatura de Lectoescritura o Literatura Infantil, desarrollan en sus descriptores objetivos que están relacionados directamente con el título de la materia haciendo referencia a las teorías de la adquisición del lenguaje en la etapa de educación infantil o los diferentes géneros literarios existentes y la importancia de éstos en dicha etapa.

Puesto que existen asignaturas que se imparten en varias universidades, he realizado el mismo paso que en la anterior tabla para obtener los descriptores, 
seleccionando los que más se acercan a mi propósito de investigación siendo en este caso aquellos que mantienen relación con la literatura infantil y más concretamente con los cuentos infantiles y aquellas asignaturas que se refieren al valor de la imagen y dibujo infantil. También he seleccionado asignaturas como: Formación Literaria para Maestros, ya que considero necesaria que se impartan materias de este tipo para formar a los futuros maestros y maestras en los distintos géneros literarios y su historia.

En este caso ocurre lo mismo que en la tabla anterior, existen asignaturas como Lectoescritura o Literatura Infantil que se cursan en la mayoría de las universidades españolas, pero se da el caso de asignaturas tales como, Cuentacuentos o Dramatización a través del cuento, que sólo se presentan en algunas universidades y de manera optativa, siendo éstas imprescindibles para trabajar en esta etapa educativa, ya que el cuento es un material didáctico empleado en todos los centros escolares para educar y considero importante trabajarlo dentro de esta titulación para mostrar la función y el efecto que este tiene en la población de infantil. Considero relevante el aprendizaje de tales asignaturas ya que muestran tanto la importancia del valor de las imágenes como de las palabras, el sexismo que puede albergar en cada material educativo mostrado y enseñado a los niños y niñas de esta etapa educativa, tan relevante para la formación y construcción de sujetos libres de los modelos culturales de género dominantes de nuestra sociedad.

Tras la revisión de materias relacionadas con la coeducación y aquellas que incluyen en su contenido aspectos sobre literatura infantil, puedo manifestar que aquellas asignaturas designadas exclusivamente para trabajar la coeducación contemplan ésta como objetivo y eje principal a abordar en sus descriptores, pero si nos fijamos en las asignaturas relacionadas con la literatura infantil, ninguna de ellas hace alusión a aspectos coeducativos. Reitero la falta de transversalidad en temas 
relacionados con la coeducación dentro del sistema educativo y queda reflejado en el análisis de dichas materias.

Es necesario reelaborar las asignaturas que se enseñan en dicha titulación porque los cambios en la sociedad son visibles y estos cambios provocan que los estudios específicos, por ejemplo en educación infantil, reformulen y reescriban su contenido, adaptándose a estos cambios y al avance de la sociedad hacia nuevos objetivos como son los nuevos modelos educativos no sexistas, es decir, coeducativos.

Actualmente las universidades españolas se rigen por la Ley Orgánica de 4/2007, de 12 de abril, que modifica a la Ley Orgánica 6/2001, de 21 de diciembre, de Universidades. Esta ley garantiza la igualdad de oportunidades y no discriminación por razón de sexo, raza, religión, discapacidad o cualquier otra condición personal o social, a la vez que se compromete a que el alumnado universitario reciba un trato no sexista y las universidades cuenten con unidades de igualdad para el desarrollo de las funciones relacionadas con el principio de igualdad entre hombres y mujeres. Por ello podemos comprobar cómo en algunas asignaturas expuestas anteriormente destaca el principio de igualdad de oportunidades entre hombres y mujeres, niños y niñas. Las universidades se comprometen a cumplir el principio de igualdad de género en sus funciones y materias, aplicándolo en sus descriptores aunque se entrevé como el principio de igualdad de género no es transversal a todas las asignaturas, sólo en aquellas que por su contenido mantienen relación con la igualdad entre niños y niñas. 
○ 2.2.2.- Lenguaje sexista como mecanismo de discriminación invisible.

El lenguaje es el arma comunicativa y espacio simbólico más potente del que disponemos para expresar aquello que queremos dar a conocer, empleándolo en la mayoría de las veces de manera errónea cuando nos posicionamos ante una visión crítica de género. Para muchas autoras y autores estudiosas del lenguaje, el inconveniente de éste, es el componente sexista que presenta, tanto en cuanto se pretende bajo el perfil de neutralidad, integrar a ambos sexos, lo que no hace otra cosa que incluir a las mujeres dentro del marco masculino que ya existe. Algunas formas sexistas del lenguaje se inscriben directamente en la práctica docente y suponen una exclusión sistemática de las niñas. En concreto, el uso sistemático y normativo del masculino para designar colectivos que incluyen a personas de ambos sexos, incluso cuando la mayoría de estas personas son mujeres o niñas, o cuando en el grupo hay únicamente un varón. En este caso el uso y el abuso del masculino tienen un efecto claro sobre el colectivo: silenciar la diferenciación sexual e ignorar la presencia y especialidad de personas de otro sexo, contribuyendo a diluir la identidad femenina ${ }^{28}$.

Es necesaria esa visibilización de las mujeres dentro del lenguaje, para dejar al margen todos aquellos sesgos patriarcales y androcéntricos que persisten en nuestra cultura, es por ello la importancia de una revisión exhaustiva de los libros de texto y materiales didácticos puesto que constituyen un recurso muy potente para presentar y representar una visión del mundo que deconstruya los estereotipos asociados a cada sexo y a la imagen preconcebida de las mujeres.

Cuando hablo del lenguaje me refiero no sólo al escrito sino también al corporal, al visual, al icónico, al simbólico, todos ellos disponen de una importante carga de

${ }^{28}$ Subirats, Marina y Brullet, Cristina. “La Coeducación....", obra citada, pp. 30 
códigos educativos que conforman la esfera educativa de los niños y niñas tanto dentro como fuera del aula. Es por tanto la importancia de conocer qué se enseña dentro del aula a los futuros profesores y profesoras de magisterio infantil, cómo se conforma el currículo de las universidades en materia de coeducación y qué implica una revisión a fondo y con mirada de género a los materiales didácticos existentes para comprobar y erradicar la existencia del lenguaje sexista empleado en ellos y es aquí donde quiero centrarme, puesto que considero que el lenguaje utilizado dentro de los recursos académicos de los que disponemos, continúa siendo sexista y pasa desapercibido dentro del sistema educativo, como lo son los cuentos infantiles. 


\section{* 2.3.- LA COEDUCACIÓN A DEBATE: DISCURSOS SOBRE UN CAMBIO}

\section{EN EL MODELO ESCOLAR.}

Este apartado consta de cuatro partes diferenciadas: la primera consiste en una revisión breve sobre aquellos aspectos relativos a propuestas históricas de Coeducación desde que la crítica feminista denunciara el problema de la educación mixta, generando distintas formas de discriminación contra las mujeres. Para ello entraré a revisar algunas de sus propuestas para la escuela, sus finalidades, estableciendo cuáles son los objetivos que marcaba la Coeducación como propuesta educativa que afronta los nuevos cambios sociales ante nuevas formas de discriminación hacia las mujeres, para conseguir a través de esta, erradicar cualquier situación desigual e injusta que limite la igualdad de género.

Puesto que mi trabajo se centra en la etapa de educación infantil, considero relevante explicar cómo es el proceso personal, afectivo y de identidad sexual que conduce a los niños y niñas a modelarse como sujetos adultos condicionados por el entramado social al que pertenecen, asignados a un determinado género $\mathrm{y}$ construyéndose a través de valores e ideales sexuados en esta sociedad dicotómica en la que vivimos, configurándose así la segunda parte de este apartado.

Esta dicotomía de hombre y mujer es reflejada en el lenguaje, contenidos y situaciones sexistas que son presentados a niños y niñas de temprana edad; es por esto que considero imprescindible trabajar con los materiales didácticos sexistas que aún son empleados en las aulas y sirven de referente para niños y niñas en su aprendizaje. La tercera parte de este bloque consistirá en una crítica a todos los materiales didácticos que se emplean en el sistema educativo y que reproducen conductas y valores sexistas hacia las mujeres, más concretamente acerca de la literatura infantil tradicional, cómo ésta reproduce y perpetúa los mismos roles asignados a las mujeres y a los hombres, el 
papel que representan éstos dentro de la literatura infantil y cómo estas conductas son consideradas como buenas y aceptadas por los niños y niñas, finalizando por una explicación crítica sobre la necesidad de aplicar la coeducación como nueva propuesta educativa para erradicar los estereotipos y conductas sexistas en educación.

Tras exponer qué función tiene la literatura infantil en los niños y niñas de esta etapa y el problema del uso de cuentos infantiles tradicionales como mecanismo de reproducción de estereotipos sexistas, el cuarto capítulo consiste en un breve recorrido por aquellos valores y aspectos que deberían presentar los cuentos infantiles para ser considerados de la literatura infantil coeducativa.

\section{○ 2.3.1.- La Coeducación: aspectos históricos y actuales.}

Hacia la mitad del siglo XIX se puede decir que la vindicación feminista comenzó a tomar cuerpo por la lucha de la educación para las niñas, desde la primaria hasta la superior, expresada como movimiento político en varios países. En nuestro país, todavía era negada la presencia femenina en los espacios universitarios hasta 1910. A mediados del siglo XIX la cuestión de la enseñanza femenina en España era un tema bastante complejo de abordar, puesto que no existían Institutos Nacionales de Enseñanza Media Femeninos, por lo que sólo podían optar a una educación aquellas mujeres que pertenecían a familias con poder adquisitivo, a través de preparación extraacadémica y con exámenes libres, a la vez que debían pasar por pruebas de acceso especialmente diseñadas para ellas y por tribunales que las examinaba por todas partes, impidiendo en muchos casos que obtuvieran el título oficial de universitarias. En esta época se crearon escuelas para enseñar a niñas, como las Escuelas Normales de Maestras, de comercio, de correos y telégrafos, de enfermeras y de mecanógrafas y 
taquígrafas $^{29}$, y a partir del 1910 ya se permite la matrícula universitaria a mujeres, aunque el proceso de acceso fue lento porque existía una fuerte tradición cultural donde las niñas y mujeres debían ser educadas para amas de casa y del cuidado del hogar.

Hasta 1970 se optaba por una escuela segregada donde niños y niñas debían aprender separados y a cada sexo se les educaría de una forma diferente. Tan sólo la Institución Libre de Enseñanza introdujo la idea y la práctica de la coeducación, mezclando a niños y niñas en una misma clase pero conservando enseñanzas diferenciadas para cada sexo. Tras los primeros tiempos del franquismo, al final de la década de los 1960 y situándose ya en los 1970, comenzó la idea de una educación mixta, creándose centros escolares públicos mixtos, donde niñas eran educadas en el mismo aula junto con los niños. La demanda de coeducación ha sido una constante desde el último tercio del siglo XIX en adelante, pero lo que se entendía por coeducación estaba lejos de las pretensiones de igualdad recientes. La coeducación se entendió en nuestro país como la educación conjunta de ambos sexos, de niños y niñas, pero no se cuestionaban los papeles asignados a los hombres y a las mujeres, ni las relaciones de género implícitas en ellos. En los años 70, la necesidad de readaptación y renovación del sistema escolar a las nuevas necesidades sociales abrió las puertas a la educación mixta (Ley General de Educación de 1970), aunque no se hizo explícito, los planes de estudio de EGB y Bachillerato fueron matizados bajo el artículo 17 y 22; ya que declaraban su pretensión de ofrecer a todos y todas la igualdad de oportunidades educativas en nombre de una sociedad más justa. Así el currículum de nuestra escuela mixta integró a las niñas en el currículum diseñado para los niños, perdiendo legitimidad hasta lo que en ese momento había sido considerado "saberes femeninos",

\footnotetext{
${ }^{29}$ Simón, Ma Elena. "El largo e imparable proceso". En La igualdad también se aprende, Cuestión de coeducación, Madrid. Narcea, S.A. 2010, pp. 26
}

\section{3}


invisibilizando a las mujeres y reforzando la idea de su escasa valía puesto que no formaban parte del espacio formal público. El nuevo modelo escolar siguió contribuyendo así, bajo la etiqueta de neutral e igualitario, a la reproducción de las desigualdades construidas y extrapolándolas a otras esferas: las familiares.

En este periodo era de interés para el Ministro Villar Palasí el desarrollo de la educación del país para que éste avanzara y se modernizara, por lo que propuso reformas en varios sentidos, dando una leve promoción de la mujer en educación. En el discurso expuesto ante la Asamblea General de la UNESCO, que contenía los principios del Libro Blanco, fue presentado por el ministro en Febrero de 1969 y en él estaban expuestas las formulaciones de un sistema educativo que ofreciera igualdad de oportunidades a todos, sin discriminaciones por las posiciones económicas o geográficas, siendo de interés principal elevar el nivel educativo y cultural de la población española ${ }^{30}$.

Pero el hecho de establecer una educación mixta, por lo tanto un avance en la educación de las mujeres no implicaba una educación basada en la igualdad entre hombres y mujeres, sino que dio a lugar a distintos posicionamientos sobre las reformas en el modelo educativo y los nuevos planteamientos acerca de la educación de las mujeres en las fechas preliminares a la Transición democrática, como argumenta Victoria Robles ${ }^{31}$, la Coeducación, incluso entre aquellos grupos más progresistas, no incluía en la mayoría de los casos una eliminación de las materias propias de las chicas, ni el cuestionamiento acerca del papel de las mujeres en la familia, que seguirá defendiendo como propio de las mujeres.

\footnotetext{
${ }^{30}$ Robles Sanjuán, Victoria. “Educadoras en la conformación de una nueva ciudadanía: feminismo y propuestas educativas transformadoras". En Robles, Victoria. Educadoras en tiempo de transición. Madrid, Morata, en prensa.

31 Ibídem
} 
Al igual que España, otros países como Portugal, Italia e Irlanda, se sumaron, aproximadamente en el año 1972, a la iniciativa de establecer un modelo mixto de hombres y mujeres dentro del sistema educativo, pero la realidad es que este modelo mixto no liberaba a las mujeres de las cargas sexistas impuestas en la escuela segregada, de hecho un factor determinante en los procesos de escolarización conjunta en todos estos países ha sido la evidencia de que, con el acceso a las mujeres a los currículum escolares no se solventaba el problema de la igualdad real.

A partir de 1970 la escolarización de las mujeres que partía de niveles muy inferiores a la de los hombres, tanto cuantitativa como cualitativamente, ha ido aumentando progresivamente y más rápidamente que la de los varones, como ya ocurrió a otra escala en la época de la Segunda República. Tomando como referencia a Marina Subirats en 1988, la cual argumentaba que la coeducación planteaba la desaparición de los mecanismos discriminatorios tanto de las estructuras de las escuelas, como de las ideologías y prácticas educativas. El término coeducación ya no sólo designaba a la inclusión del género femenino dentro del masculino, sino una fusión de las pautas culturales que anteriormente se consideraron específicas de un solo género.

Y no será hasta 1990 cuando realmente se recojo por vez primera la igualdad entre los sexos. Se promulga la LOGSE, la primera Ley de Educación de la España democrática que exige el cumplimento del principio de igualdad entre los sexos, a partir de ahí todas las leyes de carácter estatal y autonómico declaran la expresa necesidad y obligación de educar activamente la igualdad entre los sexos. La entrada del siglo XXI y una educación mixta no supone una educación en igualdad por lo que comienza la idea 
de llevar a la práctica esta igualdad real de sexos y la necesaria puesta en práctica de la coeducación para conseguir dicha igualdad ${ }^{32}$.

Pero ¿por qué no se considera la existencia de una igualdad real en educación? Como María Elena Simón argumenta: todavía se habla mucho del "sexo opuesto", perdura el mito de la complementariedad o de la media naranja, se relacionan poco en grupos mixtos de iguales (los niños con los niños y las niñas con las niñas), en definitiva, la escuela mixta no coeduca ${ }^{33}$.

La escuela mixta sigue reproduciendo ámbitos masculinizados o feminizados, no se ha avanzado en la mezcla de culturas distintas que den lugar a una nueva, sino que tan solo se centra en igualar a toda la población escolar bajo lo masculino dominante, de ahí que pensadoras y docentes feministas tras la masiva incorporación de profesoras y alumnas en la década de 1980 sintieran la necesidad de transformar la pedagogía androcéntrica $^{34}$, partiendo de que los niños aprendieran de las niñas y junto a ellas se reconociese una igualdad de oportunidades educativas, de igualdad de trato y de condiciones, no solo en el ámbito escolar sino también en el social ${ }^{35}$.

A lo largo de la década tuvieron lugar diversas jornadas de coeducación, numerosas acciones de apoyo y fomento de la coeducación, también se consiguió que parte de profesoras escribiesen y dejasen huella sobre esta cuestión, era una labor

\footnotetext{
${ }^{32}$ Robles Sanjuán, Victoria. "Cuando los cambios son también nuestros: movimientos feministas y propuestas educativas transformadoras". En Añaños, Fanny (coord...). Las mujeres en las prisiones. La Educación Social en contextos de riesgo y conflictos. Barcelona, Gedisa, 2010, pp 137-154

${ }^{33}$ Simón, Mạ Elena. "La herencia de la "mala educación". En La igualdad también se aprende, Cuestión de coeducación. Madrid, Narcea, S.A. 2010, pp. 32

${ }^{34}$ Androcentrismo: Una de las manifestaciones del sexismo que consiste en tomar al hombre varón como el prototipo o modelo de lo humano y su perspectiva como el punto de vista de la humanidad. Bajo esta forma de sexismo, el hombre y lo masculino son entendidos como centrales a la experiencia humana mientras que la mujer y lo femenino son entendidas como "lo otro" o "lo específico y particular". JASS (Asociadas por lo Justo). Diccionario de la Transgresión feminista.

${ }^{35}$ Ibídem, 33
} 
necesaria para conseguir una igualdad entre niños y niñas dentro del aula; como dice Marina Subirats:

El esfuerzo por cambiar la escuela sigue siendo necesario aunque es complejo porque la invisibilidad de las formas discriminatorias lleva a menudo a creer, por parte de todas personas involucradas en la enseñanza, que la institución es neutra desde el punto de vista del tratamiento de los géneros, pero la realidad es que sigue existiendo una enorme carga de sexismo dentro de ésta, por tanto se necesita una escuela realmente coeducativa que supere estas limitaciones sexistas que todavía se encuentran en la escuela mixta ${ }^{36}$.

A pesar de todas las luchas y movimientos para el fomento de la coeducación, tras los cambios políticos y el agotamiento en la lucha por conseguir una igualdad real de género en las aulas, se produjeron discrepancias dentro del profesorado, distintos enfoques feministas y agobios burocráticos de la educación obligatoria universal, que provocó que se dejaran de convocar muchas jornadas y encuentros ${ }^{37}$. El "espejismo de la igualdad" colapsó vías por las que podrían haberse alumbrado muchas iniciativas y esta cuestión se fue debilitando tanto que como asegura María Elena Simón ${ }^{38}$ : todavía a día de hoy, entrando en la segunda década del siglo XXI, en casi ningún ámbito de los que trabajo haciendo formación del profesorado, la coeducación es un concepto de significado compartido.

Esto se refleja en lo que socialmente significa la coeducación. El diccionario de la real academia define coeducación como; aquella educación que se da conjuntamente

\footnotetext{
${ }^{36}$ Subirats, Marina. "De la escuela mixta a la coeducación". En, VEGA, Ana. Mujer y educación, una perspectiva de género, 2007, pp. 139

${ }^{37}$ Simón, Ma Elena. "Un camino que debe ensancharse y prolongarse". En La igualdad también se aprende, Cuestión de coeducación, 2010, pp. 123

${ }^{38}$ Ibídem, 123
} 
a jóvenes de ambos $\operatorname{sexos}^{39}$. Pero esta definición de coeducación se conoce mal y el significado no es compartido, además de tener una descripción ambigua, no sólo implica una educación conjunta sino todo lo que con ella se articula, las relaciones de poder implícitas en la adjudicación de cada sexo, las desigualdades en torno a la adquisición de roles establecidos, etcétera; por ello "Coeducación" precisa de una definición más amplia, se considerada un proceso intencionado de intervención a través del cual se potencia el desarrollo de niños y niñas partiendo de la realidad de dos sexos diferentes hacia un desarrollo personal y una construcción social común y no enfrentada ${ }^{40}$

La discriminación contra las mujeres está inscrita en todos los ámbitos de las relaciones sociales, tanto públicas como privadas, debido a los factores socioculturales que nos envuelven y en los que estamos inmersos. La adjudicación de roles en función del sexo, la raza, la clase social, todo ellos forman parte de nosotras y nosotros y está dentro de nuestra cultura.

El Sistema Educativo actual en sus distintas etapas acentúa el principio de la no discriminación por razón de sexo e insiste en la necesidad de focalizar y transmitir esta idea a través de los centros escolares. Es aquí donde la propuesta de coeducación se implanta para favorecer a la igualdad de oportunidades y la erradicación del sexismo dentro del aula.

\footnotetext{
${ }^{39}$ Coeducación: Diccionario de la Real Academia Española. http://buscon.rae.es/drael/SrvltConsulta?TIPO BUS=3\&LEMA=jerarquia

${ }^{40}$ C.E.T.P. Intelhorce. "Proyecto de Coeducación: Puedes tú, puedo yo. Creemos una sociedad igualitaria desde el aula", Málaga, 2005, pp. 2
} 
En el año 2007 se crea la Guía de Coeducación ${ }^{41}$ como documento útil para trasladar a los centros educativos y mostrar que la enseñanza de modelo mixto no es la adecuada pues siguen reproduciéndose los valores sexistas y patriarcales de la educación tradicional; es por ello que el modelo coeducativo pretende implantar como principal objetivo, la eliminación de los estereotipos entre sexos superando las necesidades sociales y las jerarquías culturales entre niños y niñas ${ }^{42}$

La Coeducación ha sido una propuesta pedagógica para una educación impartida en igualdad entre hombres y mujeres. Partimos de una educación no neutral puesto que la enseñanza que los niños y niñas reciben muestra ser discriminatoria en razón del sexo, es por ello que la coeducación es un término que varía en función de los cambios sociales y de los avances en materia de educación e igualdad, muestra ser un término dinámico y flexible. Según la Guía de Coeducación, por "Coeducación” se entiende como aquella propuesta pedagógica que sirve para dar respuesta a toda reivindicación sobre igualdad realizada por la teoría feminista, proponiendo un cambio en el modelo de transmisión de ideas y de conocimiento bajo una perspectiva de género en determinados espacios dedicados al aprendizaje y enseñanza ${ }^{43}$

Podemos observar cómo esta propuesta se sustenta en la tradición de la teoría feminista, cuestionando un espacio educativo no neutral y sexista donde niños y niñas conviven y aprenden bajo estereotipos sexistas y patriarcales. Se pretende una transformación en las relaciones de género, eliminando la jerarquización e intentando deconstruir los roles establecidos para cada sexo.

\footnotetext{
${ }^{41}$ Guía de Coeducación: Documento de Síntesis sobre la Educación para la lgualdad de Oportunidades entre Mujeres y Hombres. Instituto de la Mujer: Observatorio para la Igualdad de Oportunidades. Noviembre 2007.

42 Ibídem. ¿Qué se entiende por Coeducación?, 4

43 Ibídem, 5
} 
El principio de transversalidad ${ }^{44}$ fue uno de los objetivos fundamentales dentro de la coeducación como nuevo modelo educativo, para garantizar que la enseñanza no sexista sea impartida de manera general y equitativa en todas las materias del currículo educativo. Esta Guía se considera bastante útil para enseñar, porque muestra, qué y cómo debe educarse de manera no sexista dentro de las aulas en una sociedad en el que no existe una igualdad real ni efectiva entre hombres y mujeres.

Las actuales propuestas coeducativas implican un cambio de actitud en la práctica cotidiana por parte de todos los agentes socializadores, ya sean padres, madres, alumnado, profesorado, etcétera. Y debe estar presente en cada texto académico, lenguaje empleado, en definitiva, debe ser una realidad consciente. La coeducación como nueva propuesta de modelo educativo establece unos fines que deben abordarse en su contenido para conseguir que el proceso de enseñanza y aprendizaje esté libre de contenido sexista y potencie una igualdad de género. Para ello es necesario que la coexistencia de actitudes y valores, que tradicionalmente han sido considerados de hombres o de mujeres, puedan ser asumidos y aceptados por cualquier persona independientemente del sexo, es decir, que unos valores no se identifiquen con un sexo específico, o el masculino o el femenino, sino que una persona pueda desarrollar su personalidad al margen de las barreras de género, eliminando el sexismo cultural, ideológico y en especial, la desigualdad hacia las mujeres. Para conseguir esto es necesario que la educación sea integral, lo que implica visibilizar a las mujeres en la sociedad, en los espacios públicos, como sujetos activos de la historia, cuestionando las formas de conocimiento socialmente dominantes, principalmente establecidas por hombres, y prestar atención a los procesos de afectividad y sexualidad en la que niños y

\footnotetext{
${ }^{44}$ Por transversalidad me refiero a que la práctica coeducativa debe implantarse en todas las materias y permear en todos los espacios del currículo.
} 
niñas se ven inmersos en su etapa de desarrollo personal, donde no solo la comunidad escolar, profesores y profesoras, sean partícipes de esta propuesta educativa, sino que también sean los padres, madres, niños, niñas y el personal no docente, los encargados de llevar a cabo este nuevo modelo educativo ${ }^{45}$

Por ello la importancia de trabajar los valores y proyecto de futuro, actitudes ante el sexo, sexualidad y sociedad, resolución de conflictos, educación para la paz, educación de las emociones, habilidades sociales, etcétera. Es necesaria la revisión de los proyectos curriculares, y trabajar así sobre el currículo oculto ${ }^{46}$ de nuestra enseñanza.

Forman parte del currículo oculto tanto normas, estructuras como rutinas. Aquellas estructuras de conocimiento implícitas en las técnicas de enseñanza por parte del profesorado, así como, las obligaciones que se derivan de la arquitectura de los edificios escolares. Con respecto a los materiales didácticos, quiénes son y a quiénes se refieren los sujetos de los problemas de matemáticas, los ejemplos gramaticales, etcétera. Todas las zonas de ocio que presenta un centro escolar como, los lugares de recreo, su organización y distribución. Qué personas están al mando de los cargos unipersonales, quiénes de los distintos niveles y áreas y quiénes y cómo se ocupan de los diferentes espacios escolares ${ }^{47}$.

La escuela mixta ha dejado consecuencias negativas tanto para ellas como para ellos, no se ha aprendido casi nada sobre mujeres y casi todo sobre la mal llamada "obra

\footnotetext{
${ }^{45}$ C.E.I.P. Intelhorce. "Proyecto de Coeducación: Puedes tú, puedo yo. Creemos una sociedad igualitaria desde el aula", 2005, pp. 2

${ }^{46}$ Currículo oculto: Aquellas facetas de la vida escolar de las que se aprende sin que los y las profesoras seamos conscientes de sus efectos, ni los/las alumnos/as perciban su transmisión. "Ibídem". 3

47 "Ibídem" 3
} 
humana"48, que en realidad es la obra masculina. Todo aquello que se considera "femenino" está desvalorizado y sustituido sistemáticamente por lo "masculino", considerado como superior, más prestigioso y más deseable; se aprende que las mujeres se encuentran en un segundo plano puesto que no son bien nombradas ni estudiadas, son invisibilizadas; se establecen relaciones de afectividad y sexualidad bajo la desigualdad y el abuso; se obsesionan demasiado con los modelos convencionales disfrazados de modernidad, el canon de belleza para ellas debe ser "perfecto" y el desarrollo de competitividad y fuerza física para ellos. Del mismo modo hacen elecciones académicas y profesionales sesgadas que dan lugar a sectores de actividad estereotipadas en función del género, probando que ellas estén dispuestas a aceptar condiciones laborales o despidos inadecuados, mientras que ellos prefieren ganar bien su vida en oficios más sofisticados o demasiado simples.

La generalización de la escuela mixta no ha abordado las nuevas realidades que se desprenden de una nueva situación: la igualdad de derechos de las mujeres respecto de los varones, todavía no conseguida al cien por cien ni consolidado en la práctica ${ }^{49}$. La coeducación supone encaminar la práctica educativa hacia la consecución de la eliminación de los obstáculos, invisibles o visibles, que impiden o restringen la igualdad real entre hombres y mujeres en educación; supone la corrección de los estereotipos sexistas para promover la igualdad entre los $\operatorname{sexos}^{50}$. Como Amparo Tomé argumenta, la Coeducación asume tres retos ${ }^{51}$ :

\footnotetext{
${ }^{48} \mathrm{La}$ autora se refiere a los conocimientos ancestrales, los que atribuyen a la naturaleza femenina como inferior y carente de virtudes. SIMÓN, Ma Elena. "Hasta aquí hemos llegado". En La igualdad también se aprende, Cuestión de coeducación, 2010, p. 183

${ }^{49}$ Ibídem, 184

${ }^{50}$ Subirats, Cristina y Brullet, Cristina. "La Coeducación....", obra citada, pp. 8

${ }^{51}$ Tomé, Amparo. “Educar es Coeducar”, 2005, pp. 3
} 
El primer reto consiste en hacer visible y de manera consciente, bajo una firme actitud política, todo el proceso de invisibilización que han sufrido las mujeres, menospreciando sus saberes y sus aportaciones a la ciencia, además de todos aquellos saberes que han aportado a su ámbito familiar, social, laboral, etcétera, y que no han sido representados.

El segundo reto se basa en una profunda revisión curricular incluyendo el cómo, por qué y para qué deben ser incluidos como contenidos curriculares, científicos, artísticos. Este análisis debe reflejar la exclusión que han sufrido las mujeres en torno a los curricula oficiales; los saberes básicos para la vida, la educación sentimental, la vida, las experiencias y saberes de las mujeres.

El tercer reto contempla sobretodo las diferencias que se dan en las relaciones entre el profesorado, el alumnado, ambos con las familias del centro y el personal no docente que intervenga.

Para que la coeducación sea posible y se lleve a la práctica, es necesario que se incluya dentro del marco político para que afecte y trabaje sobre la corriente dominante masculina establecida y leyes patriarcales y androcéntricas por las que se rige nuestra cultura, como es la división del trabajo en función del sexo, las jerarquías de poder, los estereotipos masculinos y femeninos impuestos y los roles asociados a ellos.

La coeducación debe instaurarse en todas las etapas educativas y puesto que mi trabajo se fundamenta en la etapa de educación infantil considero relevante trabajar en el proceso de desarrollo personal y social en el que niños y niñas se ven inmersos en esta etapa educativa, para contemplar de qué manera se desarrollan socialmente en función de un contexto específico y bajo una cultura determinada y cómo interviene la coeducación en dicha etapa. 
○ 2.3.2.- Proceso de socialización de niños y niñas y construcción social de la identidad masculina y femenina en infantil.

La educación infantil es la etapa educativa donde los niños y niñas comienzan a comunicarse y relacionarse dentro del aula con el resto de compañeros y compañeras, y no sólo en el aula. Comienzan a comprender sus diferencias sexuales y a identificarse dentro del concepto construido de niño y niña, hombre y mujer. Esta etapa es vital para la construcción de la identidad sexual, donde conformarse y colocarse dentro de unos modelos establecidos de nuestra cultura.

Según la autora Ana Ortiz Castillo, el proceso de identidad sexual y rol de género que abordan los niños y niñas de infantil se engloba en varias etapas y son las siguientes:

- De 1 a 2 años: Las niñas y los niños tienen intereses tipificados socialmente como de su sexo-género, aquellos que nuestra sociedad considera apropiados.

- De 2 a 3 años: A partir de esta edad se autoclasifican a la categoría de niña o niño con la que reconocen los elementos diferenciales uno para el hombre y otro para la mujer.

- De 3 a 5 años: Recurren a los aspectos externos de la identidad para rechazar o aceptar juguetes, vestidos, juegos, actividades y de este modo valoran como más adecuado y positivo para sí lo que la sociedad considera como propio de su sexo. 
- De 5 a 8 años: Adquieren el esquema de identidad permanente y de que ésta no depende de su voluntad o de las apariencias sino que es un hecho estable y biólogo 52 .

La socialización primaria suele ser la más importante para el individuo, los niños y niñas se identifican con los otros sujetos en una variedad de formas emocionales, pero sean estas cuales fueran, la internalización se da sólo cuando se produce la identificación. Los niños y niñas aceptan los roles y actitudes de los otros significantes o sea que los internaliza y se apropia de ellos. A través de esta identificación con los demás el individuo se vuelve capaz de identificarse a sí mismo, de adquirir una identidad subjetivamente coherente. La persona llega a ser lo que los otros sujetos consideran. $^{53}$

En el proceso de socialización se aprende a respetar, tolerar, comprender y ayudar a los demás, siendo la escuela la institución social técnica en aprendizaje, es natural que ésta contribuya a la socialización, dirigiendo intencionadamente el aprendizaje social. ${ }^{54}$ En palabras de Teresa del Valle; la socialización es central en la creación de identidades genéricas así como la forma en que se transmiten los contenidos en los momentos críticos del ciclo de vida. Una aprende a ser mujer o varón de la misma forma que aprende a ser niña, adolescente, joven, persona madura y anciana $^{55}$. Existen formas de socialización diferenciadas para las mujeres y para los varones que se corresponden, generan y son la base de las diferencias que se consideran importantes para unas y otros.

\footnotetext{
${ }^{52}$ Ortiz, Ana. "La Coeducación en la Educación Infantil”. En Innovación y experiencias educativas, 2008, pp. 2

${ }_{53}$ Berger, Peter Y Luckman, Thomas, "La construcción social de la realidad", 1991, pp.40

${ }^{54}$ Fermoso, Paciano. “La personalización, la socialización y la moralización como partes del proceso educativo", 1985, p.12

${ }^{55}$ Del valle, Teresa. "Mujer y nuevas socializaciones: su relación y cambio", 2005, pp.4
} 
La familia y la escuela han sido los ámbitos principales donde se producía el proceso de socialización, la sociedad presiona para que pensemos y actuemos de forma acorde con un determinado sexo, según sea mujer o varón y no hacerlo supone romper, enfrentarse y cambiar las normas. En cada sociedad existe una idea de lo que debe ser un hombre y una mujer y a esta idea es lo que se conoce como género. El género sería el entramado de habilidades, capacidades, funciones, expectativas, gustos, responsabilidades, etcétera, que se consideran propios de hombres o de mujeres ${ }^{56}$. A partir de los 3 años, ya se autoasignan como a una de las dos categorías, hombre o mujer, utilizando para ello atributos externos como la forma de vestirse o de peinarse. Las niñas y los niños comienzan a adquirir estereotipos de género casi al mismo tiempo que toman conciencia de su identidad de género; esta construcción precoz de los estereotipos de género, se debe al trato diferencial que niñas y niños reciben desde el momento que llegan al mundo que determina un comportamiento y unas expectativas radicalmente diferentes respecto a ellos y ellas en función de su sexo biológico ${ }^{57}$.

Cada persona tiene la necesidad de estar vinculada al sistema al que pertenece, en este sentido, la experiencia llevada a cabo en la etapa de infantil trabaja fundamentalmente los vínculos entre los alumnos y las alumnas, las maestras y los maestros, familias e institución. De hecho cada individuo establece una serie de vínculos con los sistemas a los que pertenece (familia, cultura, escuela, amigos y amigas, etcétera) y que cada uno se construye según los vínculos que adquiere, estos vínculos nos aseguran pertenencia y por tanto, influyen en nuestra forma de estar en el mundo, en este caso en la escuela y en el paso de una etapa educativa a otra. ${ }^{58}$ Así, en el

\footnotetext{
${ }^{56}$ Carrasco, Rosario, et al. "La Coeducación, una propuesta contra la violencia sexista y la violencia escolar", 2008, pp.13

57 Ibídem, 14

${ }^{58}$ Castro, Ana, et al. "La mirada infantil sobre la transición educativa”. Cuadernos de Pedagogía, Enero 2012 , no 419
} 
proceso de construcción social del niño y la niña intervienen diferentes agentes que influyen de manera decisiva en éste, ya sean los padres, madres, profesorado, alumnado, personajes de cuentos, televisión, juego, etcétera, a través de los cuales los niños y niñas adquieren modelos de ser, de vivir, de sentir y reproducen los comportamientos aprendidos y observados de su entorno, todos ellos socialmente construidos. Todo esto es lo que conforma el currículo oculto, donde los estereotipos culturales son transmitidos en la vida diaria pasando desapercibidos, puesto que han sido construidos a lo largo de décadas y se consideran como "normales" y propios de nuestra cultura.

La coeducación pretende romper esta norma cultural por la que se rige nuestra sociedad y el sistema educativo, a través de la eliminación de estereotipos y construcciones socialmente establecidos que perpetúan las desigualdades sociales y estructurales que siguen imposibilitando y dificultando que las mujeres ocupen los diferentes espacios sociales en condiciones de igualdad real.

Pero, ¿Por qué todas las sociedades presentan estos estereotipos sexistas y discriminatorios hacia la mujer? y ¿Por qué diversas herramientas educativas como los cuentos infantiles continúan reproduciendo estos mismos valores sexistas y desiguales? ¿Podemos decir que todo esto se fundamenta en construcciones sociales o existe alguna parte biológica del ser humano que nos lleve a la reproducción de los mismos esquemas sociales y conductuales?

En el estudio de los procesos de socialización siempre ha existido un debate en torno a qué se entiende por biología y qué por cultura, por ejemplo como argumenta Teresa del Valle, a las niñas se les ha considerado biológicamente más desarrolladas para habilidades verbales, mientras que los varones han destacado cualidades sobre orientación espacial, aunque los estudios no clarifican la relación entre lo biológico con 
las habilidades verbales o en orientación espacial, se hace una división en torno a qué se corresponde biológicamente con la mujer y qué con el varón y esto condiciona a la hora de transmitir con más énfasis unas orientaciones a un sexo que a otro porque se parte de la creencia que esto es así por la biología y se recalcan determinados talentos en las mujeres y otros bien distintos en los varones ${ }^{59}$

Por lo tanto el proceso de socialización es diferente para ellas y para ellos, ellos están condicionados por unos estereotipos y concepciones aceptados socialmente basados en su sexo biológico y ellas todo lo contrario, lo que no es considerado propio de la esfera masculina, por tanto, lo opuesto, se considera femenino. Este proceso es idéntico en todos los sujetos porque cada individuo en su contexto se encuentra rodeado de unos determinantes y se produce así una imitación e identificación con el resto de sujetos, los niños van adquiriendo unos roles y estereotipos a imagen de los demás niños y las niñas siguen el mismo proceso de identificación con el resto de niñas, en función de unos determinantes biológicos donde cada sexo se encaja y se construye.

Esta construcción social del concepto niño y niña es fácil observarla en los recursos didácticos que utilizan los centros educativos para el proceso de aprendizaje, todo está condicionado por lo que se considera que pertenece a la esfera masculina y a la femenina, y esto se percibe a través de la literatura infantil, más concretamente de una parte de ella, los cuentos infantiles, estas diferencias de hombre y de mujer quedan representadas en los materiales didácticos empleados para la formación de niños y niñas. Al igual que he explicado el proceso de socialización y de identificación por el que niños y niñas se relacionan con sus "iguales”, también quiero aportar una corriente

\footnotetext{
59 Del Valle, Teresa. "La naturalización de las diferencias", EN Mujer y nuevas socializaciones: su relación
} y cambio, 2005, pp.4 
psicológica que explica este proceso psíquico por el que niños y niñas identifican los estereotipos de varón y de mujer en los cuentos infantiles.

Esta corriente psicológica es conocida como "la psicología Junguiana" que utiliza Sibylle Birkhauser-Oeri ${ }^{61}$ en su libro La llave de oro: Madres y madrastras en los cuentos infantiles ${ }^{62}$.

A través de dicha corriente psicológica, Sibylle explica el sentido de los cuentos y los mitos, gracias a los estratos suprahumanos de lo inconsciente colectivo y de los arquetipos. Parte de la premisa de que los cuentos nos pueden explicar sobre la psique, porque tras la representación de estos se oculta un sentido más profundo. Ella asegura que los cuentos populares no son el fruto de elucubraciones conscientes, sino que surgen de un modo muy espontáneo y alcanzaron su forma definitiva gracias a los narradores que los volvieron a contar, por ello representan problemas humanos colectivos más que individuales, que se expresan en el lenguaje simbólico típico de lo inconsciente. El cuento es una creación inconsciente de la fantasía, comparable a un sueño, y no es el producto de una fantasía individual sino la de un colectivo, de muchas personas.

Al igual que un sueño puede reflejar un problema personal concreto, los cuentos son en parte un producto de la fantasía colectiva y pueden interpretarse como sueños de la humanidad y por tanto responden a problemas de la humanidad. Los cuentos son la

\footnotetext{
60 "Psicología Junguiana"; fue creada y promovida por Carl Gustav Jung, un psicólogo de origen Suizo bastante relacionado en sus trabajos con el filósofo Simon Freud. Jung era una figura principal en la evolución institucional del psicoanálisis y se convirtió en el arquitecto principal del movimiento psicoanalítico internacional. En el 1913 Freud y Jung dejaron de trabajar juntos y la colaboración entre ambos llegó a su fin, siendo este mismo año donde Jung calificó su psicología como analítica para separarla del psicoanálisis

61 Sibylle Birkhauser-Oeri; estudió en el Jung Institut de Zúrich y realizó un análisis con la doctora MarieLouise von Franz, conocida psicoterapeuta y especialista en literatura infantil, seguidora de la teoría Junguiana y alumna de Jung.

${ }^{62}$ Birkhauser-Oeri, Sibylle. "La llave del oro: Madre y madrastras en los cuentos infantiles", 2010, pp.14
} 
herramienta a través de la cual muchas personas interpretan su propia psique, en términos psicológicos se trata de reencontrar el acceso a lo inconsciente, y es aquí a través de lo inconsciente donde se recupera la unidad que el ser humano perdió al abandonar la infancia. Esta autora intenta demostrar cómo los cuentos son al igual que los sueños, un intento del ser humano de tender un puente hacia lo inconsciente y con ello hacia su mundo íntimo de imágenes.

Birkhauser-Oeri afirma que todos los personajes de los cuentos, como son las hadas, los dragones, las brujas y los enanos pertenecen a los niveles más profundos de nuestra psique, son representaciones arquetípicas. Según esta concepción, lo que acontece en los cuentos es una vívida realidad psíquica. Parece ser que en lo más profundo de lo inconsciente del ser humano se encuentra una especie de cámara donde se hallan los tesoros del conocimiento que conciernen a la experiencia humana psíquica.

Los cuentos nos hablan de una mentalidad muy primitiva, que procede de un tiempo en el que el ser humano proyectaba toda su psique en la naturaleza y se identificaba por completo con ella. Los árboles y los animales poseían voz propia y expresaban los pensamientos y sentimientos inconscientes del ser humano.

Todos los valores que conocemos los hemos aprendido a través de la observación, de la imitación de comportamientos, de lo que nos transmiten las personas que hay a nuestro alrededor, en definitiva de todo lo que envuelve a nuestro entorno y se queda grabado en una parte de nuestra mente desde muy pequeños y pequeñas, por ello la importancia de centrarse en el proceso de construcción social que rodea al niño y la niña en su aprendizaje desde la infancia, en cómo mostramos la realidad en la que convivimos, una auténtica realidad al margen de los estereotipos sexistas que arrastramos de generaciones anteriores, en definitiva del proceso de socialización. 
Considero necesario establecer una conexión entre el enriquecimiento que aporta leer libros de texto (a pesar del grado de sexismo que encontramos en muchos textos por su lenguaje y contenido) y las diferencias de género. Como he comprobado no se enseña lo mismo a niñas y a niños, porque atienden a unas normas socialmente construidas en función de un sexo biológico aportándoles unos estereotipos y roles a un determinado sexo y otros bien distintos, al sexo opuesto.

La lectura permite indagar y descubrir identidades muy distintas entre sí, de nuestro grupo social o cultural o de cualquier otro, pero ¿qué ocurre cuando alguien no puede acceder al enriquecimiento que produce la lectura? Las mujeres son las que menos derechos tienen en esta sociedad en comparación a los hombres, son quienes en muchas partes del mundo no pueden acceder a una educación por ser mujer, por condiciones económicas o por su clase social, es decir, en definitiva por exclusión social.

Es importarte relacionar el género con la literatura, porque no podemos olvidar que las diferentes identidades de género son una construcción social de las diferencias sexuales, hemos pasado de definir a un ser biológicamente por macho o hembra a darle el significado social y cultural de hombre o mujer.

Como señala Carlos Lomas, No existe una esencia natural de lo femenino y de lo masculino, sino un mosaico cultural de identidades femeninas y masculinas heterogéneas y en ocasiones antagónicas- adscritas a uno u otro sexo ${ }^{63}$.

Nos recuerda que el mundo sigue partiendo de dos grandes dicotomías, lo masculino y lo femenino y está reflejado en los materiales didácticos empleados en las

\footnotetext{
${ }^{63}$ Lomas, Carlos. "La construcción de las identidades masculinas en el lenguaje y en la publicidad", EN Carlos Lomas (ed.), ¿Todos los hombres son iguales? Identidades masculinas y cambios sociales. Paidós Contextos. Barcelona, 2003
} 
aulas y para la enseñanza de niños y niñas de cualquier edad, por ello la importancia de trabajar en este ámbito, para hacer público y criticar el problema del sexismo en la escritura, más concretamente y aplicado a mi objeto de estudio, en los cuentos infantiles.

\section{○ 2.3.3.- Relevancia de la literatura infantil en el proceso de socialización de} niños y niñas.

En el apartado anterior esbocé una idea de la construcción de identidades femeninas y masculinas en niños y niñas a través de la socialización primaria, como idea principal argumento que este proceso de socialización y con ello la construcción de identidades de género es una construcción social y cultural que se crea y recrea en un marco amplio de significados y prácticas que en cada contexto los individuos viven y experimentan, asumen y discrepan e incorporan para sí su condición de género ${ }^{64}$. Esto constituye la base de lo aprendido, lo vivido, lo simbolizado de generación en generación, que se transforma y a la vez continua, según se adapta la cultura a los cambios de carácter global, en un proceso de aprendizaje. La construcción del género es expresada en estereotipos, actividades, organización familiar, expectativas del género, normatividad para el género, estilos de socialización, aprendizaje del poder en el género, relaciones entre los géneros, afectos, modelos de masculinidades y feminidades que quedan reflejados en la sociedad en función de una cultura en un contexto y momento específico y se muestran a los niños y niñas a través de la educación.

\footnotetext{
${ }^{64}$ Oliva, Peña. "La formación de las identidades de género entre el alumnado de una secundaria de Yucatán, México". Directora: Victoria Robles y José Luis Aróstegui. Tesis doctoral, Universidad de Granada, 2011, pp.38
} 
El centro escolar es el espacio de transmisión de normas, valores, estereotipos, habilidades, conocimientos, actitudes y espacios, de transmisión de ideología de género, que por un lado o trabaja hacia una igualdad o bien reproduce y perpetúa las desigualdades entre los géneros. El profesorado tiene función socializadora, pertenencia social y prácticas culturales, que actúan y piensan dentro de un orden social establecido, estos son parte de la historia, capaces de enseñar y transformar sentidos y prácticas hacia una igualdad real de género ${ }^{65}$.

Por tanto, el profesorado educa bajo sus opiniones, creencias, valores, representaciones, a veces culturalmente compartidos, no siendo su carácter pedagógico neutro y objetivo, sino que están condicionados socialmente por una cultura determinada que mantiene una norma fija, consensuada y aceptada por la colectividad escolar, así como por la sociedad en general. Esta norma queda reflejada no sólo en la forma de enseñanza del profesorado, sino también del currículo interno del centro escolar, que mantiene una enseñanza basada en las normas tradicionales. Sin embargo, existen profesionales de la educación que reconstruyen y deconstruyen diariamente, entran en conflicto con respecto a la norma social, y cambian sus perspectivas y expectativas de enseñanza, para hacer del aula un espacio más igualitario. De ahí que surja la necesidad de propuestas alternativas que modifiquen las normas establecidas, para conseguir cambios en el modelo educativo, amoldando la enseñanza a los nuevos cambios de la sociedad y modificando hábitos y conductas sexistas dentro del aula. Como argumenta Pilar Ballarín, Al hablar hoy de Coeducación estamos buscando un modelo de escuela que respete y valore igualmente las aportaciones y experiencias de ambos $\operatorname{sexos}^{66}$. La escuela no es la única institución que debe involucrarse en esto, se

\footnotetext{
${ }^{65}$ Ibídem, 42

${ }^{66}$ Moreno, Maㅡ Antonia. "Analizar el sexismo es un paso hacia una sociedad más justa". En Coeducamos. Sensibilización y Formación del profesorado, 2007, pp.1
} 
entiende que la familia es el primer espacio socializador en el que un niño y niña tienen contacto, es decir, que no llegan a las aulas si ningún conocimiento como una página en blanco, al contrario, llegan marcados por unos roles y estereotipos familiares, por una sociedad en general, pero es la escuela el espacio dedicado en exclusivo para esto. A menudo se olvida que el niño o niña no llega al aula vacío, por ejemplo, de cultura literaria, cuando accede por primera vez a la escuela; antes de saber leer y escribir, los niños y niñas participan de muchas manifestaciones del folclore literario, formando parte de la cadena hablada que interviene en la recepción y en la transmisión de obras literarias de tradición oral, algunas de las cuales tienen a los propios niños y niñas como principales e incluso únicos destinatarios ${ }^{67}$.

En los primeros años de vida, niñas y niños aprenden, escuchan y practican canciones de cuna, juegos mímicos, adivinanzas, trabalenguas, oraciones, cuentos maravillosos, sencillas historias dialogadas o rimadas, canciones, etcétera, además de acceder a libros de imágenes y álbumes ilustrados. A través de los cuentos infantiles, niños y niñas reconocen sus miedos, sus deseos, sus temores o sus anhelos, de ahí la importancia que tiene este periodo el cual Pedro C. Cerrillo llama la "prelectura", o las primeras lecturas en las que los adultos cuentan o leen en voz alta relatos y cuentos a los niños y niñas más pequeños ${ }^{68}$.

La literatura infantil y juvenil (LIJ), hunde buena parte de sus raíces en los cuentos tradicionales ${ }^{69}$, lo que nos lleva al debate de la presencia de los cuentos tradicionales dentro del canon literario que se debe ofrecer en el centro escolar.

\footnotetext{
${ }^{67}$ Cerrillo, Pedro C. "Literatura infantil y juvenil y educación literaria", 2007, pp.39

${ }^{68}$ Ibídem, 49-50

${ }^{69}$ Cerrillo, Pedro C. "Literatura infantil y juvenil y educación literaria", 2007, pp.50
} 
Como asegura el autor Pedro C. Cerrillo,

cualquier canon de lecturas escolares debe ofrecer clásicos, porque en sus historias y en sus textos está contenida buena parte de la cultura y tradición del mundo, porque son modelos de escritura literaria y porque son una herencia dejada de nuestros antepasados $^{70}$.

Aunque asegura que es responsabilidad de la institución escolar escoger qué clásicos deben estar en la escuela teniendo en cuenta cuáles, cuándo y cómo deben ser leídos.

El canon o, mejor, los distintos cánones están estrechamente vinculados a momentos sociohistóricos, a contextos institucionales y a movimientos culturales [...] Ni que decir tiene que el canon oficial ha estado estrechamente unido a unas clases sociales dominantes ${ }^{71}$.

Por ello, el canon que impone el sistema educativo tiende a la arbitrariedad, está influenciado por las ideas que forman al propio sistema y por la directa relación con los contenidos del currículo escolar.

La literatura amplía el diálogo entre los niños y las niñas y la colectividad haciéndole saber cómo es o cómo se querría que fuera el mundo real. En décadas pasadas los libros infantiles se dividían en libros para niñas y para niños, no podemos olvidar, por ejemplo, las obras de Jules Verne puesto que éstas estaban destinadas a los chicos y la obra de Mujercitas de M. Louise Alcott siendo un libro más propio para ellas. Partiendo de la idea de Teresa Colomer, numerosos estudios sobre esta literatura han destacado la discriminación de género presente en los libros infantiles a lo largo de

\footnotetext{
${ }^{70}$ Ibídem, 67

${ }^{71}$ Nuñez, Gabriel. "Lecturas canónicas, clásicos y lecturas periféricas". En Cerrillo, Pedro C. y Cañamares, Cristina, Literatura infantil: nuevas lecturas y nuevos lectores, 2007
} 
décadas de literatura infantil, se puede destacar tres grandes pasos en este tipo de denuncia, el primero ha sido los cambios que se han producido en nuestra sociedad a lo largo del último siglo pudiendo encontrar obras que pueden señalar fácilmente las diferencias existentes en los valores propuestos a ambos sexos. En segundo lugar, el reforzamiento de los estereotipos que acostumbra a darse en la producción de menor calidad literaria, como los cómics o la novela rosa. Y por último, la propuesta ideológica explícita de los años setenta como denuncia sobre la creación de un nuevo didactismo $^{72}$. Se percibe una literatura-femenina, feministas y de la mujer- para señalar certeramente que la mayoría de iniciativas de los setenta podrían situarse en la segunda etapa, caracterizándose en una inversión de roles. Es decir, como ya anuncié anteriormente, los valores masculinos no fueron cuestionados, sino que simplemente se reivindicó su posesión por parte de las mujeres ${ }^{73}$.

En definitiva, la imagen de ambos géneros construidos socialmente y ofrecida por la literatura infantil y juvenil en la actualidad, refleja necesariamente los avances y lagunas del progreso social en la superación de la discriminación femenina. La reivindicación del acceso de la mujer a las actividades y conductas tradicionalmente masculinas ha dado lugar a una mayor presencia femenina y a un mayor cuidado en la descripción de sus características ${ }^{74}$. Los problemas sobre los modelos de socialización son de la literatura infantil y juvenil en la misma medida en que lo son de toda la sociedad, ésta debe representar la autentica realidad dejando explícito que cualquier persona puede hacer una opción social a partir de sus características individuales y no por el hecho de ser hombre o mujer.

\footnotetext{
${ }^{72}$ Colomer, Teresa. "Introducción a la literatura infantil y juvenil", Madrid. Editorial Síntesis, S.A. 1999, pp.45

${ }^{73}$ Ibídem, 45-46

${ }^{74}$ Ibídem, 60
} 
Los materiales didácticos empleados dentro del aula son objeto de estudio para conseguir cambios dentro del sistema educativo, ya que estos son herramientas de apoyo para transmitir valores y conocimientos, por ello la necesidad de revisar su contenido. Los cuentos infantiles forman parte de los recursos didácticos empleados dentro y fuera del aula para educar y enseñar a niños y niñas, de ahí la importancia de saber qué se está transmitiendo a través de ellos. Es necesario que estos gocen de un carácter libre de sexismo y desigualdades para ambos sexos; Teresa Colomer expone que los libros infantiles enseñan a los niños y niñas las convenciones mediante las que su cultura acostumbra a contar sus historias literarias ${ }^{75}$.

Puesto que la coeducación supone un modelo alternativo al modelo educativo vigente, se pretende que niños y niñas, futuros hombres y mujeres, sean considerados seres humanos diferentes pero no desiguales mediante una educación para la igualdad y para la autonomía. Por tanto la coeducación aplicada a los cuentos infantiles tiene el objetivo de mostrar nuevos modelos de personas, construyendo historias en torno a valores como la igualdad, la justicia o la paz que sirvan de referencia a niñas y niños, apoyando su desarrollo ${ }^{76}$.

\footnotetext{
${ }^{75}$ Colomer, Teresa. "Cómo enseñan a leer los cuentos infantiles" EN CANTERO, F, 1997, 203

${ }^{76}$ Rebolledo, Marisa. "Siete rompecuentos para siete noches. Guía didáctica para una Educación No Sexista dirigida a madres y padres", 2009, pp.9
} 
- 2.3.3.1.- Literatura clásica infantil como mecanismo de reproducción de modelos tradicionales y androcéntricos femeninos y masculinos.

Para poder hablar en términos coeducativos tenemos que revisar y ser consciente de los elementos sexistas que rodean a nuestro sistema y que forman parte de él. Puesto que mi trabajo se centra en la etapa de infantil, considero relevante revisar y vigilar estos elementos que conforman el día a día en el proceso de aprendizaje de los niños y niñas y están presentes en la construcción de identidades femeninas y masculinas. Diariamente se ven inmersos en situaciones como la adquisición de hábitos de salud, de higiene, de nutrición, la forma en que manifiestan sus necesidades básicas. Todo este proceso forma parte de la convivencia familiar ${ }^{77}$ en la que el niño y la niña adquieren aprendizajes básicos para su autonomía personal. Es importante revisar estos elementos, porque el hogar es el proceso de socialización más importante que existe en su desarrollo junto con el centro escolar.

Además de este proceso de desarrollo y de autonomía personal, el niño y la niña construye su propio espacio tanto dentro del aula como del hogar, relacionando su sexo a los elementos que le rodean, como es la elección de los juegos. Es corriente observar como la mayoría de los niños tienden a escoger juguetes más "masculinos" como; los coches, los muñecos de superhéroes, los balones, etcétera y las niñas juguetes más "femeninos" como; las muñecas, las casitas, los peluches de animales, etcétera, perpetuando la división de roles entre niños y niñas y los estereotipos creados para cada sexo. Sería necesario establecer un análisis con las familias para reformular esta práctica tradicional y deconstruir la imposición del componente sexual en los diferentes juguetes.

\footnotetext{
${ }^{77}$ Me refiero a convivencia familiar como cualquier construcción familiar en la que el niño o niña se desarrolla
} 
Lo mismo ocurre con la literatura infantil: el cuento ha sido a lo largo de los años el elemento pedagógico más usado y útil para entretener y enseñar a los niños y niñas a lo largo del proceso de desarrollo personal y académico. Con frecuencia, tenemos interiorizado una serie de personajes literarios que poseen una fuerte correspondencia con el género femenino y el masculino impuesto social $y$ culturalmente.

Tanto es así que todos y todas hemos soñado con ser el guerrero más fuerte y astuto de la comarca y la princesita más bella y sumisa del bosque que jamás haya existido. Estos patrones, que evidentemente son sexistas, son acuñados por los niños y niñas que los consideran y toman como verídicos y propios de una sociedad que se encuentra totalmente al margen de esta representatividad sexual impuesta.

La literatura infantil es el espejo de la sociedad, una sociedad creada por los adultos para transmitir una determinada imagen del mundo a sus hijos e hijas ${ }^{78}$. Esta imagen es como ellos quieren que sus niños y niñas perciban el entorno, a través de fuertes estereotipos de género inamovibles y que perduren con el paso de los años. Como argumenta Juan Mata: Cada época y cada sociedad conceptúa la lectura de acuerdo con su particular entendimiento de la vida y de la cultura. ${ }^{79}$

En los últimos años han aparecido en los cuentos infantiles personajes femeninos que han sido representados estereotipadamente como masculinos porque se han invertido los roles de género, así son fuertes, intrépidas, etcétera y lo mismo ha ocurrido con ellos, se han vuelto un poco más "sensibles", pero lo que ocurre en realidad es que

\footnotetext{
${ }^{78}$ Díaz, Juan Francisco. "El sexismo en la literatura infantil y juvenil: la discriminación de género en los libros para niños y niñas", 2010

${ }^{79}$ Mata, Juan. "La noción del placer está indefectiblemente unida a la lectura". En 10 ideas clave. Animación a la lectura. Hacer de la lectura una práctica feliz, transcendente y deseable. Barcelona: Editorial GRAÓ, 2008, pp.45
} 
las mujeres han adoptado papeles masculinos sin cuestionar lo que ello implica y viceversa $^{80}$. Se intenta ajustar a los personajes en dos modelos diferentes y opuestos, lo que nos lleva a continuar reproduciendo este sistema dualista que arrastramos desde el comienzo de la historia.

Esto forma parte de la crítica hacia los modelos tradicionales y androcéntricos femeninos y masculinos bajo los que se engloban a las mujeres y a los hombres. El sistema educativo no trata igual a mujeres y a hombres, es decir, que trata mal a las mujeres y no en igualdad. El discurso de la lucha por la igualdad de derechos e igualdad de oportunidades ha ido perdiendo fuerza y ha pasado a llamarse igualdad de los sexos o tan sólo igualdad ${ }^{81}$. Como argumenta la autora Felicidad Martínez; este debate sobre el que se pretende bajo esta "confusa" referencia de igualdad que alimenta los supuestos coeducativos actuales, se está proponiendo en realidad, una inversión, se refuerzan aquellos valores y características femeninas en los chicos y los valores y características masculinas en las chicas, penalizándose las femeninas en las chicas y las masculinas en los chicos $^{82}$. Esto se refleja en los personajes de los cuentos infantiles, como en cualquier otra esfera social, existen valores específicos que se adscriben a hombres o a mujeres y que pierden o menosprecian su mérito cuando este valor y significado corresponden al sexo opuesto.

La mayoría de las ocasiones, los cuentos infantiles de la última década poseen como personaje protagonista a un varón, y cuando la mujer aparece, suele estar representada dentro del hogar, apenas sin aparecer en la esfera pública, considerada como propia de los hombres. Todos estos roles sexuados y asumidos como reales están

\footnotetext{
${ }^{80}$ Ibídem

${ }^{81}$ Martínez, Felicidad. "Ideas que subyacen a estas políticas educativas y balance. Retos actuales en coeducación: el nuevo pacto sexual". En COEDUCACIÓN: balance y nuevos retos, 1998, pp.40 82 Ibídem, 41
} 
establecidos dentro un modelo de jerarquías que conlleva a la opresión de determinados sectores sociales y por ende a la violencia. Seguimos empleando cuentos que perpetúan modelos de género que no hacen más que promover la inequidad y relaciones de poder entre hombres y mujeres. Una gran parte del profesorado considera los cuentos infantiles como un mecanismo de transmisión de valores tales como; la amistad, la colaboración, la solidaridad, etcétera ${ }^{83}$, y es cierto pero el problema son todos aquellos valores sexistas que también aparecen en ellos y que se han transmitido de generación a generación sin ser cuestionados, ya que son parte de la cultura. No consiste en olvidar o mantener al margen aquella literatura considerada tradicional que sigue perdurando y que aún a día de hoy se sigue utilizando, sino revisarla y contarla bajo una mirada crítica de género, deconstruyendo todos aquellos valores sexistas implícitos en ella.

Entiendo por literatura tradicional todos aquellos cuentos literarios que han sido a lo largo de los años el punto de mira de todos los niños y niñas, leídos o escuchados por todo el género infantil desde décadas atrás y que aún a día de hoy siguen encabezando las listas de los libros más conocidos y leídos, como por ejemplo: Blancanieves y los siete enanitos, la Cenicienta, Caperucita Roja, la Sirenita, la Bella Durmiente, etcétera, Aunque en todos estos materiales las protagonistas son mujeres, todas tiene un papel sumiso, dependiente del varón, débiles, rol tradicional de la mujer (madre o hija al cuidado del hogar), etcétera, el perfil femenino que siempre ha acompañado a las mujeres. Como señala Santos Guerra: El libro de texto es un recurso privilegiado para analizar el sexismo escolar, es tomado como punto de referencia de

\footnotetext{
${ }^{83}$ Moreno, Ma Antonia. "Analizamos el sexismo en la literatura infantil", En Coeducamos: Sensibilización y Formación del Profesorado, 2007, pp.2
} 
aprendizaje, puede ser utilizado en solitario; además tiene un carácter prescrito dado que constituye un referente directo del aprendizaje ${ }^{84}$

El sexismo en los textos se puede identificar cuando en los mismos se encuentran ilustraciones donde se representan a los hombres y a las mujeres, desarrollando roles tradicionales, estereotipados que no reflejan las diversas actividades que pueden desarrollar tanto hombres como mujeres. Éste es un manifiesto del sexismo, donde se pone de manifiesto la negación de la realidad social y de la diversidad de las situaciones, con la consiguiente presentación de las imágenes y de los roles tradicionales masculinos y femeninos ${ }^{85}$.

Apoyándome en el Área de Juventud ${ }^{86}$, al observar un género literario de este tipo habría que preguntarse:

- En las ilustraciones, ¿se encuentran tantos personajes masculinos como femeninos?, ¿se utiliza el femenino para nombrar a las mujeres?

- En los diálogos, ¿intervienen con la misma frecuencia hombres y mujeres?

- Cuando se tratan profesiones, trabajos, deportes, etcétera, ¿las mujeres comparten con los hombres el protagonismo en estos ámbitos?

- En actividades relacionadas con el cuidado y la atención a las personas, ¿participan en la misma medida hombres y mujeres?, ¿se atribuyen indistintivamente las cualidades a hombres y a mujeres? $\mathrm{O}$ ¿se percibe claramente una jerarquización de estereotipos en función del sexo?

\footnotetext{
${ }^{84}$ Santos, Miguel Ángel. "Cultura que genera la evaluación en las escuelas”. En las prácticas culturales en el aula: metodología y evaluación, 1996

${ }^{85}$ Reinoso, Isabel. "El sexismo en la educación", 2009

${ }^{86}$ Área de Juventud. Educación y Mujer del Cabildo Insular de Tenerife. "Coeducación a través de la lectura", 2005, pp.43-44
} 
No consiste en una guía para analizar si los cuentos son sexistas o no, sino una categoría de análisis donde posicionarse ante una mirada crítica de género, detectando casi sin ser consciente, que situaciones son sexistas y cuáles no lo son.

Gracias a la crítica feminista sobre la educación sexista y del currículo y materiales académicos discriminatorios hacia las mujeres empleados dentro del sistema educativo, se han elaborado documentos y materiales coeducativos al respecto. En 1974 las feministas norteamericanas ya presentaron ante el Ministerio Nacional de Educación qué recomendaciones y pautas había que seguir para incorporar libros no discriminatorios a las bibliotecas escolares ${ }^{87}$ y potenciar así un aprendizaje basado en la igualdad de género eliminando cualquier rasgo sexista y desigual.

Más adelante, en la década de los 80, en España hubo figuras importantes con respecto al tema de la coeducación, como $\mathrm{M}^{\mathrm{o}}$ José Urruzola, Marina Subirats, Amparo Tomé, Adela Turín, entre otras. Todas ellas han elaborado materiales que trabajan en la posibilidad de una educación no sexista dentro del modelo mixto que poseemos, una propuesta de coeducación real dentro de las aulas, han cuestionado el "sistema educativo igualitario" que tenemos y reflejado las prácticas sexistas que se continúan perpetuando dentro del aula. Por ejemplo, Adela Turín elaboró una colección de cuentos infantiles titulada $A$ favor de las niñas ${ }^{88}$, una literatura infantil alternativa a la tradicional marcada por los estereotipos y componentes sexistas en su contenido, (más adelante reviso esta colección de cuentos ya que la empleo para la parte metodológica de mi investigación).

Como ya he mencionado, Amparo Tomé analiza en qué consiste la coeducación y por qué la necesidad de aplicar esta nueva propuesta pedagógica al sistema educativo,

\footnotetext{
${ }^{87}$ Moreno, Ma Antonia. "Analizamos el sexismo en la literatura infantil”..., obra citada, pp.1

${ }^{88}$ Turín, Adela. "A favor de las niñas: una colección de libros para la coeducación". Madrid. Lumen
} 
ha servido de referente nacional e internacional en la lucha de una educación igualitaria llevando a la práctica la coeducación en las aulas. Estas autoras citadas, han elaborado documentos y libros sobre una educación en igualdad, bajo perspectivas de género donde el empleo de propuestas como la coeducación sirvan para erradicar el sexismo en materiales didácticos, conductas, lenguaje y prácticas curriculares, dentro de los centros educativos, es por ello que las menciono en mi trabajo, por su importante contribución a esta temática y sus conocimientos y estudios sobre la coeducación.

Como aseguran las autoras Naima Brownie, Pauline France y Sue Duxbury, la desigualdad en cuanto al género constituye uno de los obstáculos principales para el establecimiento de un sistema de escolarización genuinamente igualitario ${ }^{89}$. Haciendo referencia al lenguaje como obstáculo para lograr una igualdad real, desviamos la atención a la literatura, a las canciones infantiles, a los mitos, a las leyendas, etcétera, al por qué la sociedad continúa aferrándose a ellos, a los tradicionales, a los de siempre.

Los libros ilustrados como son los cuentos infantiles considerados de la literatura tradicional, enseñan a los niños que ellos, naturalmente activos y dinámicos, tienen una importancia mayor que las niñas que son pasivas, limpias y ordenadas, tranquilas, soñadoras, amables, sensibles y dóciles ${ }^{90}$. Las imágenes estereotipadas de la mujer y del hombre que son transmitidas, no hacen otra cosa que reflejar la sociedad dualista en la que nos encontramos, la constante reproducción del sistema androcéntrico que nos envuelve y nos obliga a "dicotomizar" los géneros, y con ellos, sus respectivos "estereotipos": sumisa-desobediente, torpe-audaz, dócil-rebelde, emocional-insensible. Se tiende a simplificar los modelos de los personajes femeninos dejándoles tan sólo dos

\footnotetext{
${ }^{89}$ Browne, Naima y France, Pauline. "Hacia una educación infantil no sexista", 1988, pp. 16

${ }^{90}$ Turin, Adela. "Los cuentos siguen contando, algunas reflexiones sobre los estereotipos". En Cuadernos inacabados, 1995
} 
opciones: obediencia al modelo clásico o renuncia de la "feminidad” y la Imitación de los modelos masculinos ${ }^{91}$.

Con frecuencia estas imágenes de ambos sexos, preconcebidas y enseñadas a los y las jóvenes a través de la literatura, tienen más fuerzas que la propia realidad que les rodea dando lugar a un aprendizaje y reproducción de los roles sexuados. Los libros de texto empleados para el aprendizaje social y personal de niños y niñas legitiman los modelos a seguir.

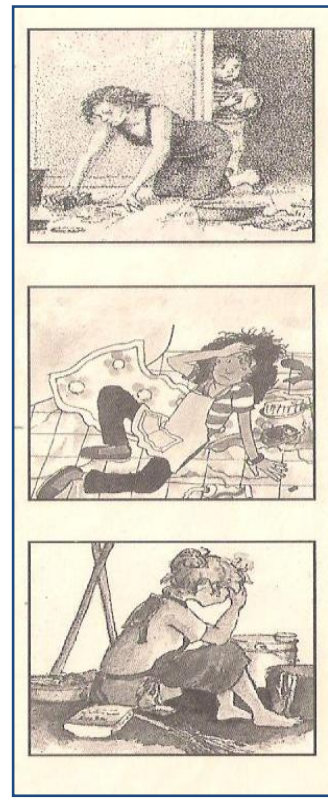

Por ejemplo, es curioso el papel que recibe "la madre" en los cuentos infantiles tradicionales, pasando de una representación como madre auxiliadora y bondadosa a una bruja mala,destructora y envenenadora. Las madres de los libros infantiles no tienen profesión ni oficio, no hacen deporte, no muestran intereses culturales, no invitan ni son invitadas, no van al cine, no se pasean, tampoco tienen amigas ni amigos: sus relaciones se limitan a los vínculos familiares y a las relaciones impuestas por la vida social de los niños.

Fuente: Turín, Adela. En Los cuentos siguen contando. Algunas reflexiones sobre los estereotipos. 1995, pp.18

Las imágenes de la madre sobrecargada de trabajo, fatigada, agobiada, hablan a los niños y niñas de las pesadas obligaciones, de las frustraciones y de la esclavitud que sufre la madre en el hogar. Esto es una realidad, pero los libros no la ponen en cuestión ni proponen soluciones para modificarlas ${ }^{92}$.

\footnotetext{
${ }^{91}$ Turin, Adela. “Un sillón, un delantal, un niño = una familia”. En Boletín de la Institución Libre de Enseñanza, no 42/43, dedicado a la literatura infantil y juvenil, 2001

92 Turin, Adela. "Los cuentos siguen contando, algunas reflexiones sobre los estereotipos". En Cuadernos inacabados, 1995, pp.26
} 


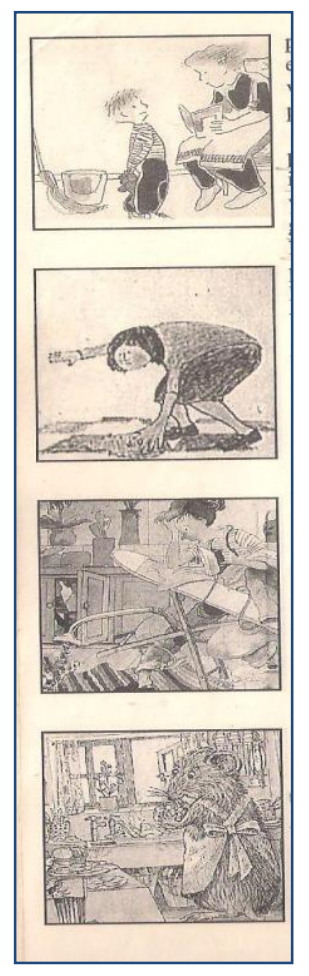

En la inmensa mayoría de libros infantiles tradicionales donde la madre es representada lavando los utensilios de cocina, sin hacer otra cosa que limpiar la casa y ocuparse del marido (porque se da por hecho que la mujer está casada y es con un hombre) y de los hijos e hijas, podemos observar dos figuras de madres opuestas la una a la otra, es decir, la madre que se le atribuye al niño único y la madre que se asocia con la niña ${ }^{93}$.

La madre del niño es representada como la madre-sirvienta. Es vista como una madre lastimosa, sin arreglar, joven, paciente, agotada y al servicio del hijo y la hija.

Fuente: Turín, Adela. En Los cuentos siguen contando... pp.19

Por otro lado encontramos la madre de la hija siendo a su vez joven pero mejor vestida y peinada, y dispone de algo de tiempo para dedicarse a ella y responder a sus preguntas. (Como asegura la autora, se entrevé que se encarga de enseñarle los saberes del hogar, para que perpetúe su rol de ama de casa). Actúa con un papel más severo y represivo y la hija mantiene una relación más estrecha con la madre que con el padre.

Por contraposición encontramos el papel del padre, éste es mucho más disperso y amplio puesto que él se encarga de la esfera pública y a su vez puede disfrutar de más aventuras en su día a día. Suele aparecer representado como el padre ausente, qué sólo aparece para la hora de la comida y cena, se presenta como un hombre inteligente que lee el periódico y muestra momentos de cariño hacia sus hijos e hijas a la hora de acostarlos.

\footnotetext{
${ }^{93}$ Ibídem, 27 
Al percibir estos roles asignados a padres y madres dentro de la literatura infantil, no sólo hay que cuestionarse por qué se siguen reproduciendo con el paso de los años, sino también qué tipo de modelo de familia se está representando, una familia tradicional y heterosexual formada por la figura de un bio-hombre y una bio-mujer ${ }^{94} \sin ^{2}$ dar la posibilidad de cuestionar esta construcción familiar y dar por hecho que es la única y válida, cuando la realidad muestra que existen muchas más con la capacidad de educar incluso de una forma más igualitaria porque sobre ellas recae el peso de la discriminación y desigualdad, debido a su componente de no tradicional y mantenerse al margen del sistema heteronormativo que nos envuelve.

Al igual que las imágenes estereotipadas de hombres y mujeres representadas en los materiales didácticos implican desigualdad en los géneros, también el lenguaje sexista influye de manera determinante en el proceso de socialización de los niños y niñas. El lenguaje, además de ser el reflejo de las ideas, usos y costumbres de generaciones anteriores, es el medio con arreglo al cual estructuramos nuestra forma de aprender la realidad es por esto que los conceptos, las creencias y las conductas, que hemos acuñado, están influidos por la lengua que hablamos. El lenguaje condiciona toda la educación y dificulta desde el inconsciente de las personas que se abra paso la idea de igualdad entre ellas.

Por tanto, los libros de texto transmiten parte de una cultura, unos modelos de vida que va conformando unos valores que penetran de forma inconsciente en el alumnado. Estos valores androcéntricos van configurando en niñas y niños una imagen genérica profundamente sexista, por ello la necesidad de trabajar bajo nuevas propuestas

\footnotetext{
${ }^{94}$ Platero, Raquel. . "La masculinidad de las biomujeres: marimachos, chicazos, camioneras y otras". En http://www.trasversales.net/t17rq.htm, en línea, 2009
} 
educativas que se dirijan hacia la consecución de la eliminación del sexismo en todas sus formas, en los materiales didácticos empleados para la educación de niños y niñas. La coeducación forma parte de la innovación educativa y de la renovación pedagógica de orientación feminista ${ }^{95}$, consiste en reformar el canon académico de manera que pierda su sesgo androcéntrico y se torne hacia la visibilización de las mujeres en todas las épocas y lugares dado que han tenido una parte importante en la historia, trabajar los principios democráticos de libertad, igualdad y paridad, materializados en los valores cívicos de empatía, respeto a la diversidad y solidaridad. Como argumenta María Elena Simón:

esto traducido al ámbito educativo equivale a educar contando con las mujeres y los varones como pares que, sumados, van a dar como resultado la convivencia pacífica, tanto en las estrechas y cercanas relaciones amistosas y amorosas, como en las más sociales y colectivas como puedan ser las políticas y económicas ${ }^{96}$.

\subsection{4.- Aspectos coeducativos a revisar en los cuentos infantiles}

La superación de los estereotipos vigentes es uno de los objetivos fundamentales de la coeducación para conseguir la igualdad entre ambos sexos, una educación con perspectivas de futuro para las posteriores generaciones donde los y las jóvenes tendrán que convivir en una sociedad con diferentes modelos de vida y géneros.

\footnotetext{
${ }^{95}$ Simón, Ma Elena. "Un camino que debe ensancharse y prolongarse". En La igualdad también se aprende, Cuestión de coeducación, 2010, p.119

${ }^{96}$ Simón, Ma Elena. "La escuela, lugar preferente para la igualdad". En La igualdad también se aprende, Cuestión de coeducación, 2010, p.137
} 
La elaboración de los materiales didácticos debe inspirarse en la superación y eliminación de todos aquellos estereotipos con carácter desigual y sexista porque una educación discriminatoria carece de calidad y se mantiene al margen de la realidad. En cada libro que se facilita al alumnado hay unos mensajes que son incorporados a la concepción del mundo que están desarrollando; por lo tanto debemos seleccionar qué literatura y qué mensajes queremos dar, para que tengan una visión real del mundo y se enriquezcan de esta propia visión evitando caer y reproducir los estereotipos sexistas.

Para que un cuento goce de ser coeducativo primero tiene que deconstruir para poder después construir, es decir, tiene que mantenerse alejado de cualquier estereotipo sexista que acompañe al personaje, como aparecen representados la mayoría de ellos en las obras literarias tradicionales y así quitar la carga sexista y desigual de la que parten. Los cuentos representan deseos y sueños que todas las personas tenemos por lo que tienen que acercarse a la realidad lo mejor posible ya que de ahí depende que luego los niños y niñas adopten roles y modelos de conductas partiendo de dichos cuentos.

Considero relevante exponer, bajo mi criterio de género y conocimiento en aspectos relacionados con la coeducación, cuáles son las temáticas que un cuento coeducativo debería abordar. El concepto de familia, hace ya tiempo que dejamos de lado la familia tradicional heterosexual porque no representa la realidad, son muchas las personas que poseen un modelo de familia alternativo sin necesidad de una relación de consanguineidad, o como requisito imprescindible poseer un padre o una madre biológicos, de la misma forma que existen familias sin necesidad de tener hijos o hijas.

Son multitud las tipologías de familias que existen en la sociedad, es por ello que debería quedar reflejado en la literatura infantil para enseñar al niño y niña que no solo existe un modelo de familia sino que una familia es el espacio en el que cada individuo 
siente su propio hogar. Existen parejas homosexuales con hijos e hijas adoptados que seguro forman un modelo de familia con menos prejuicios y estereotipos que cualquier otra más tradicional, porque ellos mismos han vivido la opresión de llevar la etiqueta de “anormal” por mantenerse al margen de la línea dominante de esta sociedad patriarcal y heteronormativa. Las familias son construcciones sociales y lo que importa en ellas son los valores que se transmiten a los y las menores con ideas liberales y sin contenido sexista.

Otro aspecto importante son los roles asociados a la mujer y al hombre, consiste en que los estereotipos de género se acerquen a la realidad y no a la inversión de los roles estereotipados tradicionalmente al hombre y a la mujer. De nada sirve que ahora las princesas de los cuentos monten a caballo y maten dragones y ellos se dediquen al cuidado del palacio a la espera de que la princesa los rescate, porque siguen siendo valores desiguales y jerárquicos a la vez que implican dependencia de un personaje hacia el otro. La cuestión es: ¿Tienen las niñas que ser por obligación una princesa? Existen multitud de personajes que no implican unos estereotipos de base, la primera imagen que tenemos al pensar en una princesa es la de sumida, bella, dependiente, obediente, callada, es decir "perfecta" (bajo una mirada patriarcal y androcéntrica), pero quizás los autores y las autoras de los cuentos infantiles no se han planteado que el único fin a alcanzar de una niña no sea el de ser una princesa, si los materiales didácticos emplearan otro tipo de deseos y sueños para las niñas, seguro que estas no desearían ser una princesa sino cualquier otro personaje.

Otro aspecto importante a reflejar en los cuentos infantiles sería el multiculturalismo. Es importante señalar la diversidad de culturas que conviven en una misma sociedad, esto es un hecho que existe en la realidad, desde que tenemos la posibilidad de cruzar fronteras y cambiar de país (evidentemente siendo esto más fácil 
para algunas personas que para otras) pero es necesario reflejar siempre la realidad en la literatura infantil, para que niños y niñas perciban y reciban los positivo de la convivencia entre diversas culturas, que entiendan lo enriquecedor que es mezclar una cultura con otra bajo la toleración, esto también es coeducación.

También tenemos que mostrar la cultura de paz, no a la violencia generalizada en todas sus formas, es mucho más fácil ver a diario la violencia que cualquier acto pacifista, porque desde muy pequeños y pequeñas nos educan bajo una cultura de guerra y estamos colapsados de noticias sobre países en guerra, esto es importante mostrarlo, pero como una crítica hacia las sociedades que no escogen el camino pacifista para solventar los problemas y utilizan las armas y la violencia para llegar a cualquier acuerdo. Al igual que el respeto a las demás culturas y razas, es importante señalar la variedad cultural desde donde evitar el racismo y prejuicios culturales.

Existen multitud de cuentos, sobre todo los tradicionales, que reflejan la religión como algo común en todas las familias, pero la sociedad no muestra este aspecto como algo común y generalizado. Existen personas que basan su fe en una determinada religión, sea cual sea, y otras muchas que no. Es importante señalar que a pesar de que la religión haya sido durante muchos siglos un hecho común en las familias, la sociedad ha cambiado y está cambiando, donde muchas familias prefieren mantenerse al margen de ella, y por ello hay que mostrar la posibilidad de una sociedad laica. Se debe reflejar la variedad de religiones existente, cada una propia de una cultura, y todas iguales de respetables, aunque muchas de ellas (por no decir la mayoría) albergan sexismo en su contenido, siendo esto bastante cuestionable a la hora de coeducar.

Considero relevante tratar el tema del feminismo, ya sea en la literatura infantil, o en cualquier material educativo empleado en la escuela, a día de hoy todavía existen 
personas que desconocen su significando y cometido, es algo que debería enseñarse desde edades muy tempranas para que sea interiorizado y todas las personas se construyan bajo un pensamiento feminista y sobre una mirada de género, y así evitar tanta desigualdad y sexismo que alberga en el pensamiento de muchos individuos, sobre todo por tanto desconocimiento y nociones erróneas, hay que conseguir que el feminismo sea una doctrina transversal a todos los ámbitos.

Tenemos que dejar a un lado el concepto normalidad, ¿qué consideramos como normal y que no?. En muchos cuentos infantiles he percibido que toman como normal aquellas conductas y situaciones tradicionales que se han dado siempre, con el paso de los años, en una determinada cultura, por ello debemos evitar emplear este concepto acuñado a unas determinadas situaciones porque lo que para nuestra cultura occidental puede considerase "normal", en la otra parte del mundo puede ser de lo más atípico y diferente. Esto ocurre porque partimos desde una mirada etnocéntrica criticando el resto de culturas desde la nuestra propia, considerándola como la mejor y única lo que nos lleva a juzgar a las demás partiendo desde nuestros prejuicios culturales.

Esta normalidad también la podemos percibir en personas que poseen alguna discapacidad tanto física, como psicológica, sensorial, etcétera, y son discriminadas por ello, encuentran dificultades en su día a día porque la sociedad no pone alternativas para facilitarles la vida y con frecuencia se encuentran con problemas de accesibilidad tanto laborales, educativas, de salud, como en las infraestructuras, urbanismo, edificación, etcétera, perjudicándoles desenvolverse y hacer vida con total independencia en su medio. Debe quedar reflejado en los cuentos infantiles para que se perciba la tolerancia y el respeto hacia todas las personas sean cuales fueran sus situaciones personales y animar a la independencia y autonomía de cada persona bajo sus propios medios y recursos. 


\section{3.- LA LITERATURA INFANTIL NO SEXISTA: METODOLOGÍAS PARA SU ANÁLISIS}

Para realizar este trabajo, comencé por documentarme sobre las nuevas propuestas pedagógicas por parte del profesorado para producir cambios en el modelo educativo que tenemos, es decir, de la intención de proponer un modelo coeducativo al actual sistema educativo y que se ha pretendido desarrollar en los colegios del marco español, para ello realizo una búsqueda sistemática y revisión bibliográfica sobre los documentos y materiales que tratan esta cuestión, y centrándome en la literatura infantil de la que disponemos a día de hoy considerada "coeducativa" 97.

Para ello, he seleccionado varios cuentos infantiles de edad comprendida entre cero y seis años y así poder comprobar, bajo una visión de género y revisando elementos coeducativos tales como; los roles y estereotipos aplicados a cada género, la variedad en la construcción de distintos modelos de familias, las relaciones afectivosexuales entre personas del mismo sexo, la construcción de la identidad sexual, etcétera, si estos cuentos cumplen los objetivos sobre qué es la coeducación y si bajo mi criterio sobre ésta ${ }^{98}$, se pueden considerar coeducativos o si continúan las mismas líneas sexistas y desiguales que caracteriza a los cuentos infantiles tradicionales.

Los criterios de búsqueda y de selección de los cuentos infantiles han sido, por un lado, observar si la Junta de Andalucía propone un listado de cuentos infantiles para trabajar tanto dentro como fuera de los centros escolares y por otro, comprobar si

\footnotetext{
${ }^{97}$ Como aquella que pretende introducir cambios en el modelo educativo que tenemos, erradicando resquicios de sexismo que aún se mantiene tanto en el lenguaje y materiales didácticos, como en la organización y disposición de la clase.

98 Entiendo por coeducación la propuesta pedagógica que se fundamenta en romper los estereotipos sexistas y visibilizar a las mujeres como sujetos autónomos e independientes, a la vez que representar la realidad de las acciones de los grupos feministas y aquellos que promueven y luchan por una igualdad de género.
} 
existen páginas oficiales o recomendadas por alguna administración pública que trabaje literatura infantil. Estas dos vías de búsqueda han sido las seleccionadas puesto que los poderes públicos y los organismos oficiales están comprometidos a cumplir el principio de igualdad de género desarrollado en las leyes de educación del marco español.

Finalmente, el listado de cuentos infantiles seleccionado lo he obtenido de la página de la Junta de Andalucía, puesto que esta establece recomendaciones sobre qué literatura infantil es aconsejable trabajar en los centros educativos a través del Servicio de Orientación a la Lectura (SOL). Con este listado me dispongo a conocer cuáles son, de entre todos ellos, los libros más demandados por los lectores y las lectoras, para así obtener diversos cuentos infantiles más destacados entre la población de infantil y servirme de éstos para hacer la parte metodológica de análisis de texto y de imagen. He decidido obtener dicha información partiendo de las recomendaciones de la Junta de Andalucía, porque a la luz de la normativa coeducativa, debe atender y cumplir con el principio de igualdad de oportunidades entre hombres y mujeres que los poderes públicos están obligados a desarrollar y a hacer efectivo en su disposición y desarrollo.

Han sido varias las limitaciones a las que he tenido que hacer frente puesto que, cada centro escolar posee diferentes criterios de selección de cuentos infantiles para trabajar dentro del aula.

En algunos de ellos es el propio profesorado quien decide qué cuentos infantiles trabajar y en otros son los padres y madres quienes orientan a la directiva del colegio sobre los materiales que ellos trabajan dentro del hogar, lo que me dificulta para el momento de escoger que vía o vías utilizo para seleccionar los libros infantiles que se trabajan actualmente. Es por ello que he optado por las orientaciones que la Junta de Andalucía hace en materia de literatura infantil para todos y todas. 
Como ya he señalado a lo largo de este texto, mi intención es conocer si se está produciendo una nueva generación de literatura infantil no sexista, a raíz de los avances en la conciencia social en materia de igualdad y de las nuevas propuestas pedagógicas, como es la coeducación, para introducir cambios en el modelo educativo por parte de los docentes y profesionales de la enseñanza. Para ello voy a realizar un análisis de contenido, tanto de texto como de imágenes y comprobar así qué nuevo modelo de sujeto construyen, si es más igualitario y si se mantiene al margen de los estereotipos masculinos y femeninos sexistas, propios de la literatura infantil tradicional, para mostrar cómo han cambiado los personajes, las acciones, el lenguaje, las ilustraciones, etcétera y trabajar estos aspectos para indicar si existe una nueva generación de literatura infantil no sexista y en ese caso, cómo se fundamenta.

Acercándome a los cuentos detecto un grado de conciencia educativa en la sociedad y en el sistema educativo, editorial, literario, etcétera, que fomente la existencia y uso de una nueva generación de literatura infantil coeducativa. Con ello me propongo mostrar cómo los cuentos infantiles son formadores de identidades y de estereotipos de género, por ello la importancia de trabajar desde una visión de género y utilizando propuestas coeducativas.

En este estudio es mi interés dar a conocer la necesaria incorporación de propuestas coeducativas que modifiquen aspectos del sistema educativo para su mejora con respecto a temas de igualdad de género, como es la revisión y modificación de los materiales didácticos y textos empleados en el aula por su contenido sexista y desigual, más concretamente en los cuentos infantiles. 
Mis criterios de búsqueda y de selección, como he mencionado en el apartado anterior, se han fundamentado en partir de las recomendaciones que la Junta de Andalucía establece ya que, como es un organismo público está obligado y debe comprometerse con el principio de igualdad de oportunidades entre hombres y mujeres que marca la legislación vigente en España sobre educación.

Por tanto, el listado de cuentos infantiles seleccionado por ser los más utilizados por la población lectora, ha sido:

\section{* ¿Hay algo más aburrido que ser una princesa rosa?}

Díaz Reguera, Raquel (texto e ilustraciones) “¿Hay algo más aburrido que ser una princesa rosa?” Barcelona: Thule Ediciones, S.L. 2012

\section{*Una fiesta sin igual}

Guinea Díaz, Juan (texto) y Cordero López, Ma José (ilustraciones) "Una fiesta sin igual" Bilbao: A Fortiori Editorial. 2011

\section{*Las tres mellizas hacen las paces}

Capdevila, Roser (texto) y Capdevila Carles (ilustraciones) "Las tres mellizas hacen las paces" Madrid: Icaria Editorial. 2001

\section{*Una mamá para Owen}

Dane Bauer, Marion (texto e ilustraciones) "Una mamá para Owen” Barcelona: RBA Libros, S.A. 2007

\section{*Inés tres pies}

Solinís, Tessie (texto) y Barba, Alejandra (ilustraciones) "Inés tres pies". México: CIDCLI, S.C. 2004

\section{*QQué guapa eres, Plu!} 2011

Dunbar, Polly (texto e ilustraciones) “iQué guapa eres, Plu!” Madrid: Kókinos, 
La Guía de buenas prácticas para favorecer la igualdad entre hombres y mujeres en educación ${ }^{99}$ elaborada por la Junta de Andalucía, establece orientaciones de cómo debe ser un cuento infantil coeducativo, o más bien, qué debe incluir para que éste realmente abogue por propuestas igualitarias entre ambos sexos y contenga en su análisis aspectos coeducativos.

Se trata de analizar el lenguaje que emplean los cuentos infantiles, si éste es ambiguo o si representa a ambos sexos por igual y si se visibiliza a las mujeres y sus aportaciones a lo largo de la historia. Consiste en comprobar también los contenidos que dichos cuentos seleccionan y el enfoque con el que los abordan, cómo es representada la historia, si se hace referencia a los saberes de las mujeres, si se cuestionan las tradiciones científicas y se introducen nuevas visiones de la realidad, si se rompe con lo interno-externo, personal-social, racional-afectivo y privado-público. Y revisar a su vez, las ilustraciones que los cuentos presentan, si éstas muestras situaciones reales y los cambios sociales, si las mujeres son representadas al igual que los hombres, realizando las mismas actividades y en el mismo contexto y si muestran las diferencias personales como una potencialidad, no desde una óptica paternalista.

Todos estos compromisos que quedan reflejados en la Guía y están orientados a la elaboración de materiales didácticos coeducativos. Son los que la Junta de Andalucía emplea en sus recomendaciones para la elección de unos cuentos infantiles u otros, y bajo los que me fundamentaré para la elaboración de mi análisis.

Para comenzar el análisis de los cuentos infantiles, voy a centrar la parte metodológica en el análisis de texto (estructura narrativa, análisis lingüístico y de

\footnotetext{
${ }^{99}$ Blanco García, Nieves. "Materiales curriculares coeducativos". En Guía de buenas prácticas para favorecer la igualdad entre hombres y mujeres en educación, 2005, pp.74-82 
discurso) y análisis de imagen. Para ello he seleccionado varios autores que trabajan una metodología específica para el análisis de las distintas partes.

\subsection{2. - ANÁLISIS DE TEXTO}

\section{- 3.1.1.- Análisis de la estructura narrativa}

Para realizar el análisis de la estructura narrativa parto de los trabajos de Jean Michael Adam ${ }^{100}$ quien distingue cinco constituyentes básicos en la secuencia narrativa $^{101}$ : Sucesión de acontecimientos, unidad temática, transformación, unidad de acción y casualidad. Estos cinco constituyentes habitualmente crean un esquema narrativo canónico formado por cinco secuencias:

Tabla $4^{102}$. Análisis de la estructura narrativa

\begin{tabular}{|c|l|}
\hline $\begin{array}{c}\text { Secuencia } \\
\text { Situación } \\
\text { inicial }\end{array}$ & $\begin{array}{l}\text { Se parte de una situación estable. Se presentan los personajes } \\
\text { principales, el espacio y la época así como las relaciones. }\end{array}$ \\
\hline $\begin{array}{c}\text { Inicio del } \\
\text { conflicto }\end{array}$ & $\begin{array}{l}\text { Llamada también inicio de la acción, del nudo o de la complicación. Hay } \\
\text { una acción o acontecimiento que modifica la situación inicial e introduce } \\
\text { una tensión }\end{array}$ \\
\hline Conflicto & $\begin{array}{l}\text { Es la reflexión o la actuación. Uno de los participantes desarrolla una } \\
\text { serie de acciones para intentar resolver el conflicto }\end{array}$ \\
\hline $\begin{array}{c}\text { Resolución } \\
\text { del } \\
\text { conflicto }\end{array}$ & $\begin{array}{l}\text { Llamada también, fin del conflicto o de la acción, desenlace. Es el } \\
\text { resultado de las acciones precedentes, el fin del proceso }\end{array}$ \\
\hline $\begin{array}{c}\text { Situación } \\
\text { final }\end{array}$ & Vuelta a una situación estable, generalmente distinta de la inicial \\
\hline
\end{tabular}

Fuente: Elaboración Propia

Este esquema voy a utilizarlo para describir el contenido de cada cuento infantil, relatando las situaciones que se plantean y encasillándolas en cada una de estas

\footnotetext{
${ }^{100}$ Adam, Jean-Michel y Lorda, Clara-Ubaldina. "Lingüística de los textos narrativos" Barcelona: Ariel Lingüística, 1999

${ }^{101}$ LLUCH, Gemma. “Análisis de narrativas infantiles y juveniles". 2003, pp.48

102 Esquema quinario: Adam, Jean Michel $(1992,1999)$ En Lluch, Gemma. Análisis de narrativas infantiles y juveniles, 2003, pp.48
} 
secuencias, ya que como asegura la autora Gemma Lluch en su libro: Análisis de narrativas infantiles y juveniles, ésta es la estructura narrativa que mantienen la mayoría de las narraciones de tradición oral y la que se considera prototípica de la narrativa infantil, organizando los hechos cronológicamente.

He escogido este autor para analizar la estructura narrativa porque como argumenta Gemma Lluch en dicho libro, éste estudio de las secuencias o partes de un relato que dicho autor elabora, es la estructura más común que aparece en los cuentos infantiles.

\section{- 3.1.2.- Análisis Lingüístico}

Para el análisis lingüístico voy a emplear las tres categorías que según el autor Genette $^{103}$, se pueden distinguir en el relato de una obra literaria, estas tres categorías son:

Tabla 5. Análisis lingüístico

\begin{tabular}{|c|l|}
\hline $\begin{array}{c}\text { Discurso } \\
\text { contando o } \\
\text { narrativizado }\end{array}$ & $\begin{array}{l}\text { El narrador cuenta lo que dicen los personajes de manera que puede } \\
\text { manipular más las palabras que cita y crea una mayor distancia pero } \\
\text { también puede contener mayor información en menos palabras }\end{array}$ \\
\hline $\begin{array}{c}\text { Discurso } \\
\text { transpuesto }\end{array}$ & $\begin{array}{l}\text { En estilo indirecto no da la garantía de fidelidad literal a las palabras } \\
\text { que realmente pronunció el personaje porque la presencia del } \\
\text { narrador se nota demasiado. El narrador introduce el discurso a } \\
\text { través de una oración subordinada condensando, integrando y en } \\
\text { definitiva, interpretando aquello que se dice }\end{array}$ \\
$\begin{array}{c}\text { Discurso } \\
\text { restituido o } \\
\text { directo }\end{array}$ & $\begin{array}{l}\text { El narrador finge que cede la palabra a su personaje. El narrador se } \\
\text { limita introducir el discurso del personaje para crear la sensación de } \\
\text { que se expresa libremente así se establecen dos niveles: el del } \\
\text { narrador y el de los personajes, que se traducen en dos niveles de } \\
\text { lenguaje }\end{array}$ \\
\hline
\end{tabular}

Fuente: Elaboración Propia

${ }^{103}$ Genette, Gérard, (1989), pp. 228-229. En Lluch, Gemma. Análisis de narrativas infantiles y juveniles, 2003, pp.80 
Es decir, ¿cómo es contada la historia? Analizaré la posición del narrador y del personaje en el momento de describir los hechos que acontecen, para saber cómo son representadas sus acciones en el contexto del relato.

\section{- 3.1.3.- Análisis de discurso}

Para realizar el análisis de discurso escojo la metodología de Teun A. Van Dijk ${ }^{104}$; donde se entiende el discurso como un "acontecimiento comunicativo" que incluye interacción conversacional, textos, gestos e imágenes, entre otras significaciones, entre las que son importantes para este autor, las cogniciones sociales y personales, entendidas como representaciones que involucran creencias, valoraciones y emociones. Se ocupa del vínculo entre el discurso y la sociedad, entre lo personal y lo social y entiende que el discurso es diferente en cada situación comunicativa.

Para ello voy a establecer tres categorías de análisis y comprobar cómo el cuento infantil las representa y las trabaja con respecto a las acciones y los personajes. He escogido dichas categorías porque bajo mi visión sobre coeducación, son aspectos relevantes que considero deben trabajarse en la elaboración de materiales didácticos en la etapa de educación infantil.

Estas categorías van a ser:

*Resolución de conflictos: Entiendo por esto el procedimiento escogido para solucionar los problemas, acciones o acontecimientos que modifican la situación inicial e introduce una tensión.

*Igualdad de género: Con ello me refiero a cómo son representados los estereotipos masculinos y femeninos en los distintos personajes, si se percibe

\footnotetext{
${ }^{104}$ Van, Teun. "Análisis crítico del discurso". En Wodak, Ruth y Meyer, Michael, Métodos del análisis crítico del discurso. Barcelona: Ed. Gedisa, S.A. 2003
} 
claramente un sexo determinado con sus correspondientes valores asociados tradicionalmente o éstos se alternan indistintivamente del género asignado.

*Valores tradicionales y emergentes: Esta categoría se refiere a aquellos valores que siguen manteniendo una línea tradicional o si por el contrario los autores y autoras de los libros infantiles introducen valores nuevos y modernos al margen de los valores que tradicionalmente han aparecido representados en este género literario.

\section{2.- ANÁLISIS DE IMAGEN}

Para el análisis de imagen escojo la metodología utilizada por Roberto Aparici, Agustín García y Manuel, Valdivia ${ }^{105}$. Ésta se realiza a dos niveles: Denotación y Connotación.

La denotación es lo que literalmente nos muestra la imagen, es lo que percibimos inmediatamente, se conforma por todos los elementos observables. Lo aplico para ilustrar las características de las imágenes que representan a las mujeres y a los hombres, así como todos aquellos rasgos visibles que la imagen evoca.

La connotación se refiere a aquella imagen que no es mostrada, no es observable directamente y tampoco es igual para todos los receptores. Está estrechamente ligada a un nivel subjetivo de lectura, demuestra las sensaciones que se captan a través de la imagen.

En este análisis enfatizo en la descripción de lo afectivo, las posturas, todo aquello no se percibe a simple vista pero puede dar un significado detallado de la historia. Como aspectos de género a revisar en las ilustraciones, voy a mirar el

\footnotetext{
${ }^{105}$ Aparici, Roberto, García, Agustín y Valdivia, Manuel. “La imagen”. Madrid: Universidad nacional de educación a distancia, 1992
} 
protagonismo que tienen los personajes, esto se comprueba mediante la posición que éstos ocupan en el plano y el tamaño; del mismo modo, el tipo de dibujo que se emplea para representarlos; si es dibujo realista, dibujo esquemático o fotografías. El aspecto físico que mantienen los personajes, si son sexualmente estereotipados. Si aparecen representados toda la variedad de hombres y mujeres existentes, edad, clase social, origen étnico, etcétera. La espacio físico que ocupan los hombres y las mujeres, su lugar de trabajo, de ocio, etcétera. 


\section{4.- LOS CUENTOS INFANTILES A ANÁLISIS}

Para el análisis de los cuentos infantiles, comenzaré realizando un breve resumen del argumento de éstos y después partiré de la metodología explicada anteriormente, para completar el análisis de texto (estructura narrativa, análisis lingüístico y de contenido) y de imagen, basándome en la información que he obtenido de cada relato, así como, diversas fotografías de aquellas imágenes que sean relevantes y descriptivas de los libros infantiles, apoyándome en ellas para llevar a cabo el análisis de imagen. 


\section{1.- ¿Hay algo más aburrido que ser una princesa rosa?}

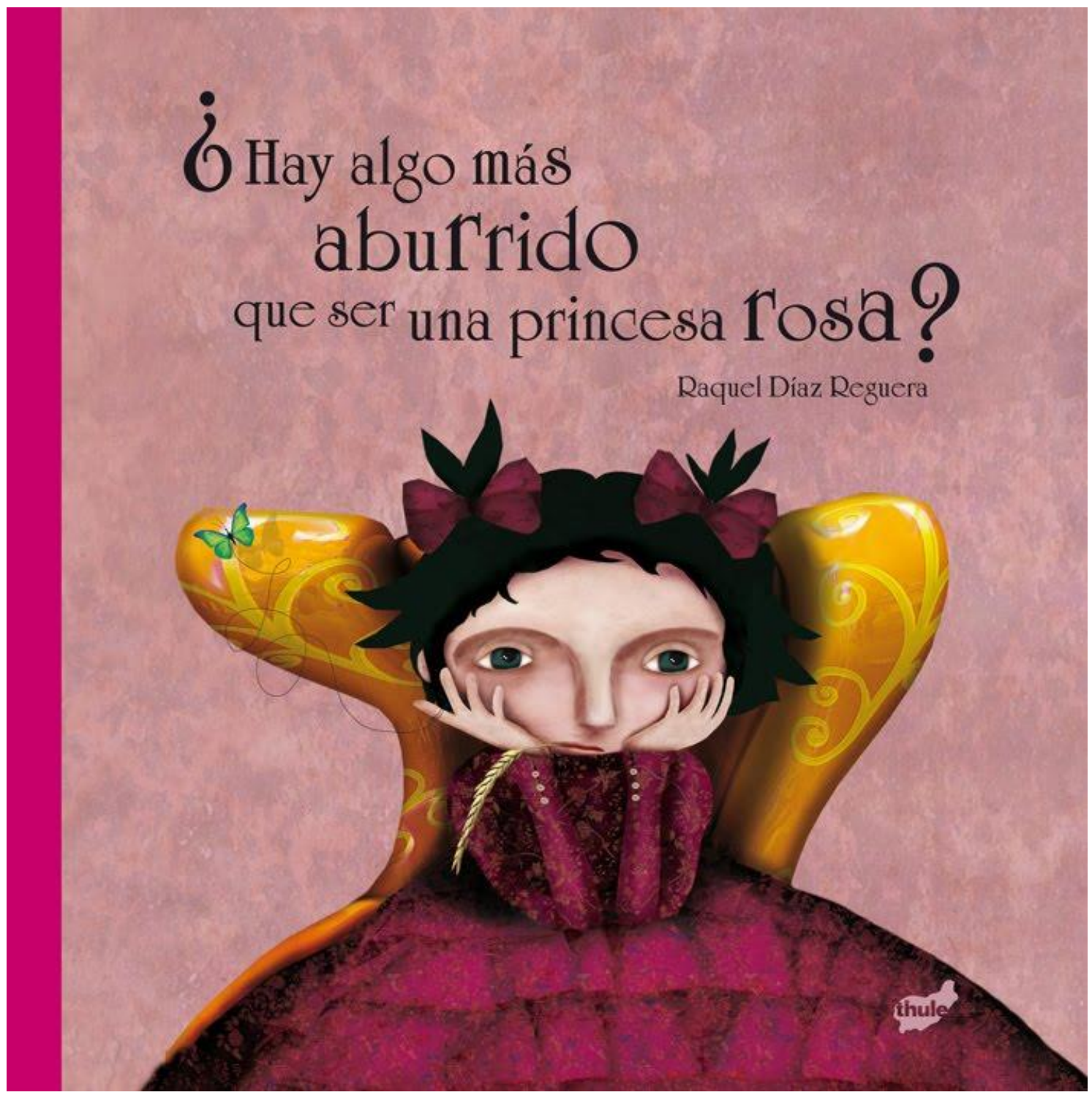

Díaz Reguera, Raquel. ¿Hay algo más aburrido que ser una princesa rosa?

Barcelona: Thule Ediciones, S.L. ( $3^{\mathrm{a}}$ ed.) abril de 2012. [( $1^{\mathrm{a}}$ ed.) noviembre de 2010, (2 ed.) septiembre de 2011] 
- $\quad$ El cuento está dirigido a niños y niñas de entre cinco y siete años. Éste relata la historia de una princesa que por tradición va vestida de rosa, tiene todos los complementos rosas y habita en un palacio rosa con cuarto rosa, como todas las princesas de los cuentos infantiles. Su padre es el rey y va de azul, al igual que la madre, la reina, que también viste de rosa y todos los demás personajes viven en un maravilloso palacio con sus roles y estereotipos asignados en función del sexo.

Un día, la niña llamada Carlota, decide que no quiere ser esa princesa tan delicada y bella vestida de rosa, ella quiere jugar, saltar, brincar y hacer todas aquellas cosas que le han sido prohibidas por su sexo y por su estatus social. Carlota se pregunta por qué ella no puede surcar los mares para descubrir nuevos lugares y disfrutar de nuevas aventuras, quiere jugar con otros niños y niñas y ser una niña "corriente" que pueda hacer lo que desee sin estar sujeta a los roles que le han asignado por tradición. Ella no quiere casarse ni tener un príncipe azul, es por ello que manifiesta su descontento ante su familia y el consejo de sabios o mejor dicho, el consejo de hadas madrinas, y se reúnen para decidir qué hacer ante esta situación.

Todas las personas que conviven con ella le explican que puesto que es una princesa y es niña debe vestir de rosa y tener cuidado, porque es delicada como una flor, pero ella no es una flor ¡es una niña! y no quiere estar sometida a esas reglas machistas y sexistas que le imponen. Finalmente el consejo de hadas decide que la niña es eso, una niña y debe jugar y hacer lo que le apetezca sin considerar su sexo, edad o estatus social, al mismo tiempo resuelven que ella tiene que elegir la ropa y el color que desee, dejando a un lado el color rosa que siempre le acompaña.

- Como se observa en la estructura narrativa que representa esta obra, aparece visiblemente cuál es la situación inicial del personaje, relatando su vida en el 
castillo, luego establecen el inicio del conflicto cuestionando por qué ella debe mantener unos roles y continuar unas reglas, y es donde aparece el conflicto, queriendo cambiar esta situación y enfrentándose al problema, más tarde se da la solución a este conflicto y finalmente el personaje vuelve a tener una situación estable, pero diferente a la inicial.

- La obra es contada por la autora pero cede la palabra al personaje principal, en este caso la niña, y al resto de personajes, por tanto basándonos en las tres categorías que establece el autor Genette, el relato presenta un forma de discurso restituido o directo, ya que el narrador es el encargado de relatar los hechos pero cede la palabra a sus personajes, para dar una sensación de que éstos se expresan libremente.

- Para el análisis de contenido y usando las tres categorías expuestas anteriormente (Resolución de conflictos, Igualdad de género y Valores tradicionales y emergentes), el libro hace una crítica a todos los estereotipos que se asignan a cada persona en función del sexo y en este caso, también se aplica al estatus social como es el de princesa, que implica ejercer unos roles determinados mostrando la jerarquía que conlleva pertenecer a la nobleza. Es llamativo comprobar cómo Carlota quiere ejercer profesiones o realizar actividades que no son propias para su sexo, según ha establecido la tradición y su cultura, estas actividades serían más propias del género masculino si partimos de dos géneros diferenciados en esta sociedad. Se puede entender que la autora está invirtiendo los roles de género, el femenino quiere tomar parte del espacio público al que pertenece el masculino, como salir del castillo y disfrutar de nuevas aventuras, surcando mares o cazar dragones, propio de los guerreros, a la vez que hace una comparación de la mujer con la naturaleza, la comparan con una flor, delicada y bella, tan sólo para embellecer los espacios sin otra finalidad que crecer, reproducir y morir. En la siguiente imagen se pueden observar estos valores tradicionales, cómo se 
perpetúan los roles asignados a cada sexo y su funciones en un determinado estatus social, como la comparación que la autora establece entre naturaleza y mujer.

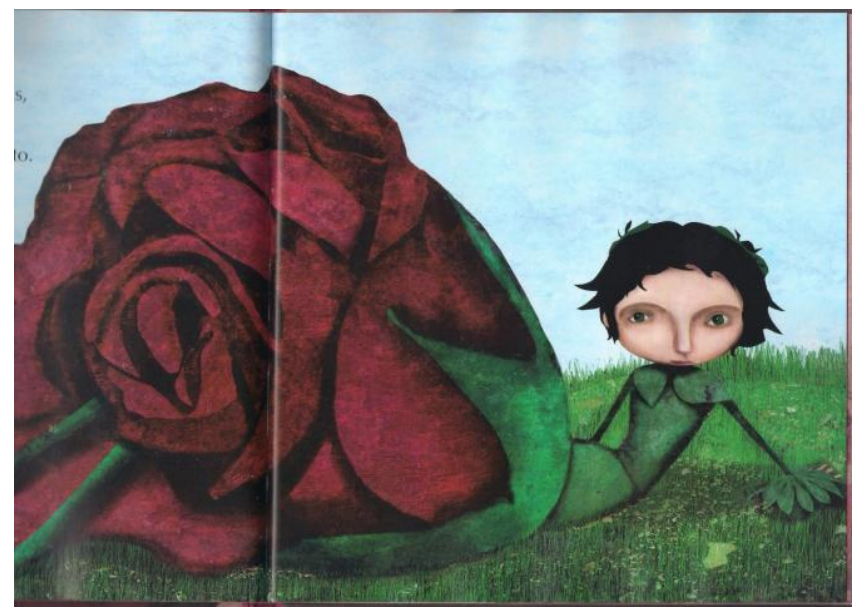

Imagen 1

Fuente: Díaz Reguera, Raquel. ¿Hay algo más aburrido que ser una princesa rosa?, 2012, pp.21-22

Es débil, bella, destaca su función reproductiva, es delicada, dulce, débil, sensible. Todos estos aspectos se asocian a las flores y a las mujeres, es una crítica a la relación entre las mujeres y la naturaleza, que destacan en muchos cuentos infantiles tradicionales.

Un aspecto interesante a destacar en el cuento es como la niña se rebela contra ese sistema patriarcal y argumenta, que tan sólo es eso, una niña, y quiere poder disfrutar de su alrededor sin prejuicios ni estereotipos, ni tener que perpetuar la tradición porque es sexista y oprime a las personas, sin opción a ser libres, en definitiva, reivindica una igualdad de género, reivindica su identidad como mujer y persona autónoma, el poder hacer las mismas funciones que un niño, porque vale igual que él y tiene las mismas capacidades que sus compañeros del sexo opuesto. Ella no quiere 
casarse ni tener que convivir con un príncipe al que le hayan asignado por la fuerza o tradición, desea elegir libremente lo que quiere ser y con quien quiere estar. El libro termina con el comentario de un príncipe preguntándose qué pasará con ellos, ahora que las princesas ya no se dedican enteramente a ellos y han modificado sus roles, y la hada madrina le contesta que ahora ellos pueden vestir de rosa.

La obra establece nuevos valores al margen de los tradicionales, valores de autonomía, independencia, liberación, etcétera. Aunque el libro invierta los roles para cada sexo, se puede interpretar como la lucha contra los prejuicios que poseemos en función del sexo o de cualquier otra cualidad. Cómo ellos pueden vestir de rosa y no tener necesariamente a una princesa a su lado que dé la vida por ellos y cómo ellas son libres para hacer lo que deseen sin tener que depender de la figura del varón y ser sumisas el resto de su vida, porque así lo diga una tradición. El libro finaliza resolviendo el problema pacíficamente, de forma consensuada y objetivamente, de manera que la niña puede elegir libremente qué hacer con su vida y cómo divertirse sin verse obligada a mantener unas costumbres sexistas.

La autora deja una pregunta abierta al final del libro, ¿Por qué todas las niñas quieren ser princesas?. Creo que es algo que muchas personas nos cuestionamos cuando estudiamos las desigualdades que conlleva reproducir estos roles, pero todo radica en lo atractivo que implica el mantener la tradición, puesto que se sustenta de posiciones jerárquicas y a su vez desiguales para las mujeres, por ello que la mayoría de los hombres no cuestionan lo que implica mantener las tradiciones, porque ellos pueden disfrutar de posiciones sociales y privilegios que por su sexo les son concedidos y que a las mujeres nos son negados. La solución radica en la propia enseñanza, si a una niña se le enseña el atractivo de surcar mares, matar dragones y ser astrónomas, no desearán ser 
princesas con sus correspondientes estereotipos, porque estos son mucho más aburridos que cualquier otro, a su vez que implican opresión y desigualdad.

- Durante toda la obra podemos comprobar cómo la autora escoge el color rosa para describir todas las imágenes que tienen relación con la protagonista del cuento, Carlota, y con azul todo lo que tiene que ver con el sexo masculino y con las acciones consideradas propias del varón. Los estereotipos en función del sexo quedan muy marcados en el cuento a través de los colores y de las vestimentas empleadas, usando tacones para las mujeres y vestidos pomposos, además de diferenciar claramente a través de la imagen, las acciones que se consideran de hombres y las que se consideran de mujeres, como besar sapos o leer libros rosas y surcar mares o ser astronautas.

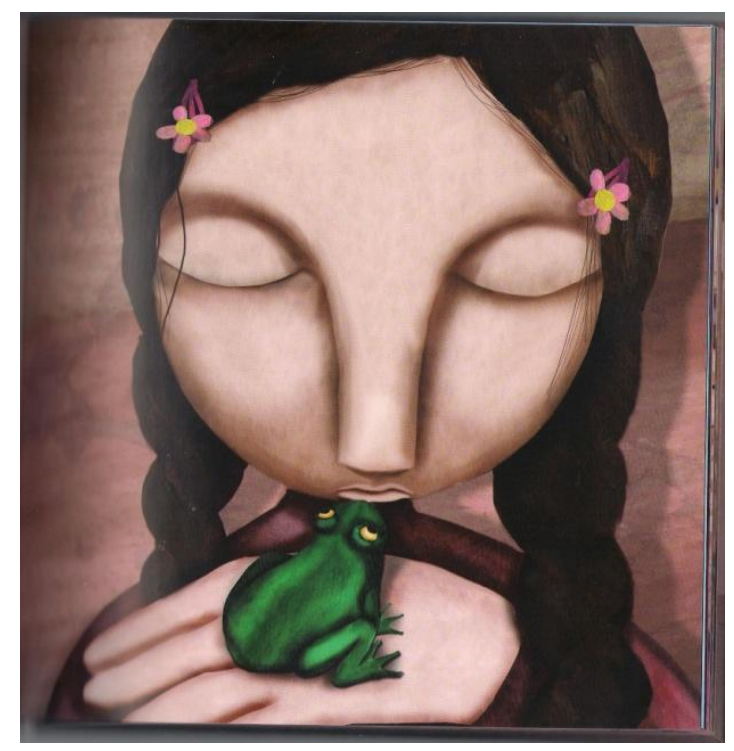

Imagen 2

Fuente: Díaz Reguera, Raquel. En ¿Hay algo más aburrido...?, obra citada, pp. 6 
Como imágenes que manifiestan sentimientos y deseos que no se perciben a simple vista, puedo destacar algunas de ellas en la que la niña quiere cazar dragones y buscar tesoros, la imagen es representada con la niña junto al dragón y montada en un barco, demostrando su fortaleza y su valentía, esto es lo que percibo al observar la imagen y lo que me evoca, son características atribuidas tradicionalmente a los hombres.

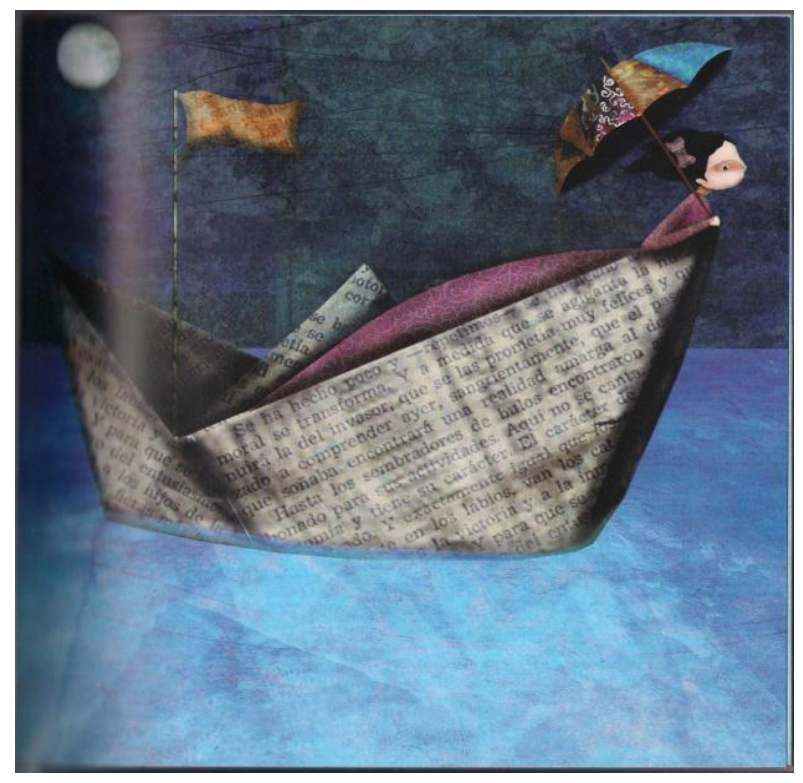

Imagen 3

Fuente: Díaz Reguera, Raquel. En ¿Hay algo más aburrido...?, obra citada, pp.8

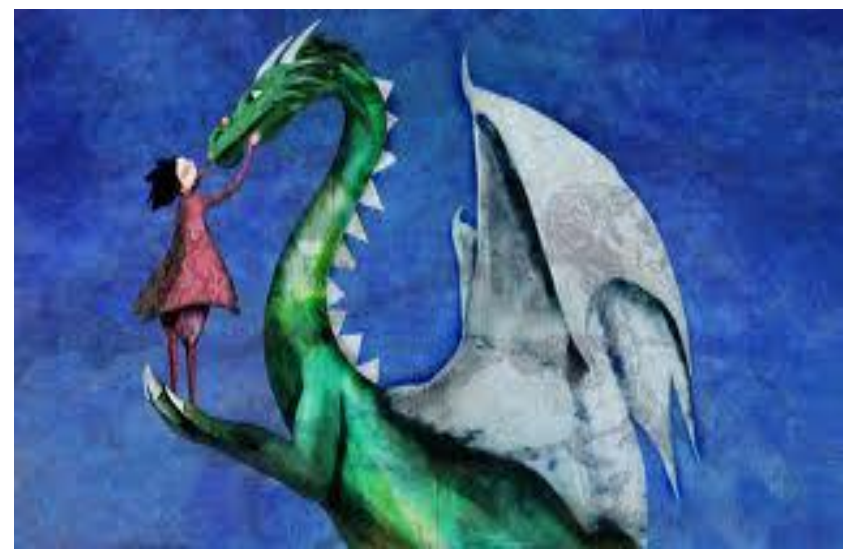

Imagen 4

Fuente: Díaz Reguera, Raquel, En ¿Hay algo más aburrido...?, obra citada, pp. 11-12 
El libro finaliza con la imagen a la izquierda de un armario lleno de vestidos rosas, y a la derecha con una jaula abierta donde las mariposas se escapan, dando a entender que Carlota ha conseguido la libertad que deseaba al desprenderse de sus hábitos impuestos y normas establecidas, y pudiendo salir fuera, a la calle, a disfrutar y divertirse, a la vez que se pregunta: ¿Por qué todas las niñas quieren ser princesas?, como una crítica irónica de lo negativo que conlleva ejercer ese rol con los estereotipos que acompaña.

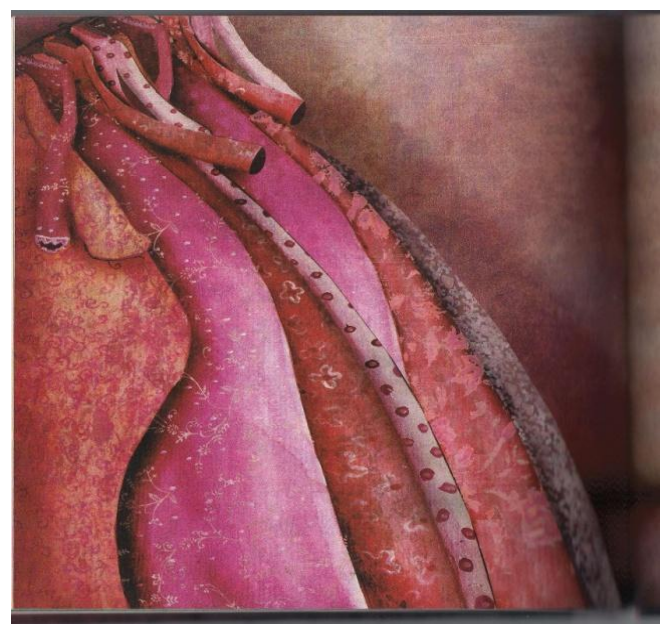

Imagen 5

Fuente: Díaz Reguera, Raquel. En ¿Hay algo más aburrido...?, obra citada, pp. 35 


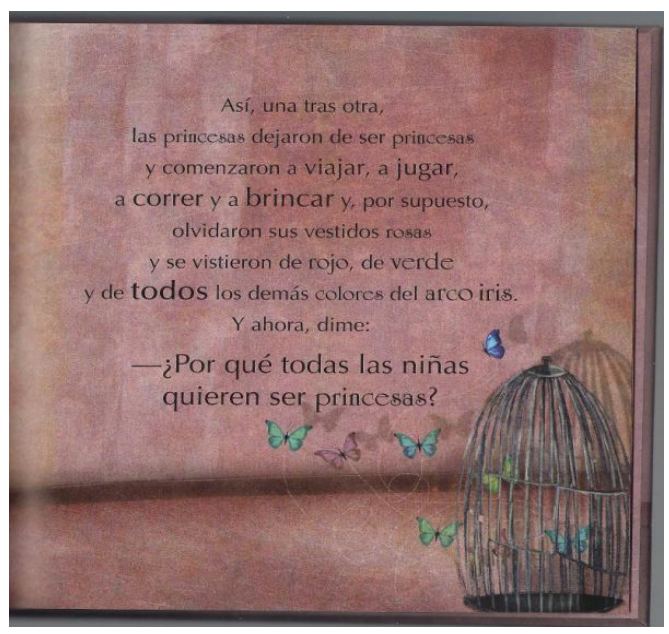

\section{Imagen 6}

Fuente: Díaz Reguera, Raquel. En ¿Hay algo más aburrido...?, obra citada, pp. 35

Carlota finalmente es representada con un yo-yo, vistiendo ropa cómoda que le permite moverse y dejando a un lado los tacones que le oprimen, siendo sólo una niña que quiere jugar y divertirse, propio de su edad.

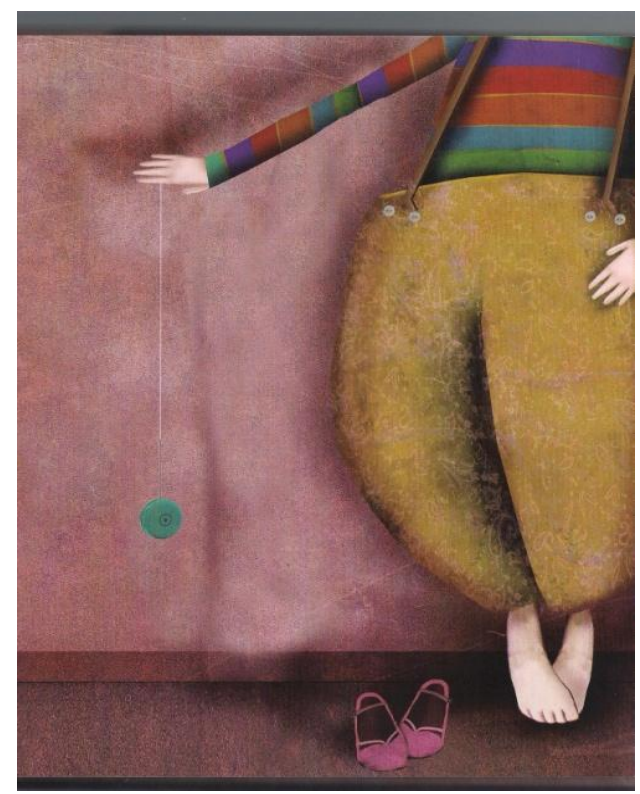

\section{Imagen 7}

Fuente: Díaz Reguera, Raquel: En ¿Hay algo más aburrido...?, obra citada, pp. 38 


\section{2.- Una fiesta sin igual}

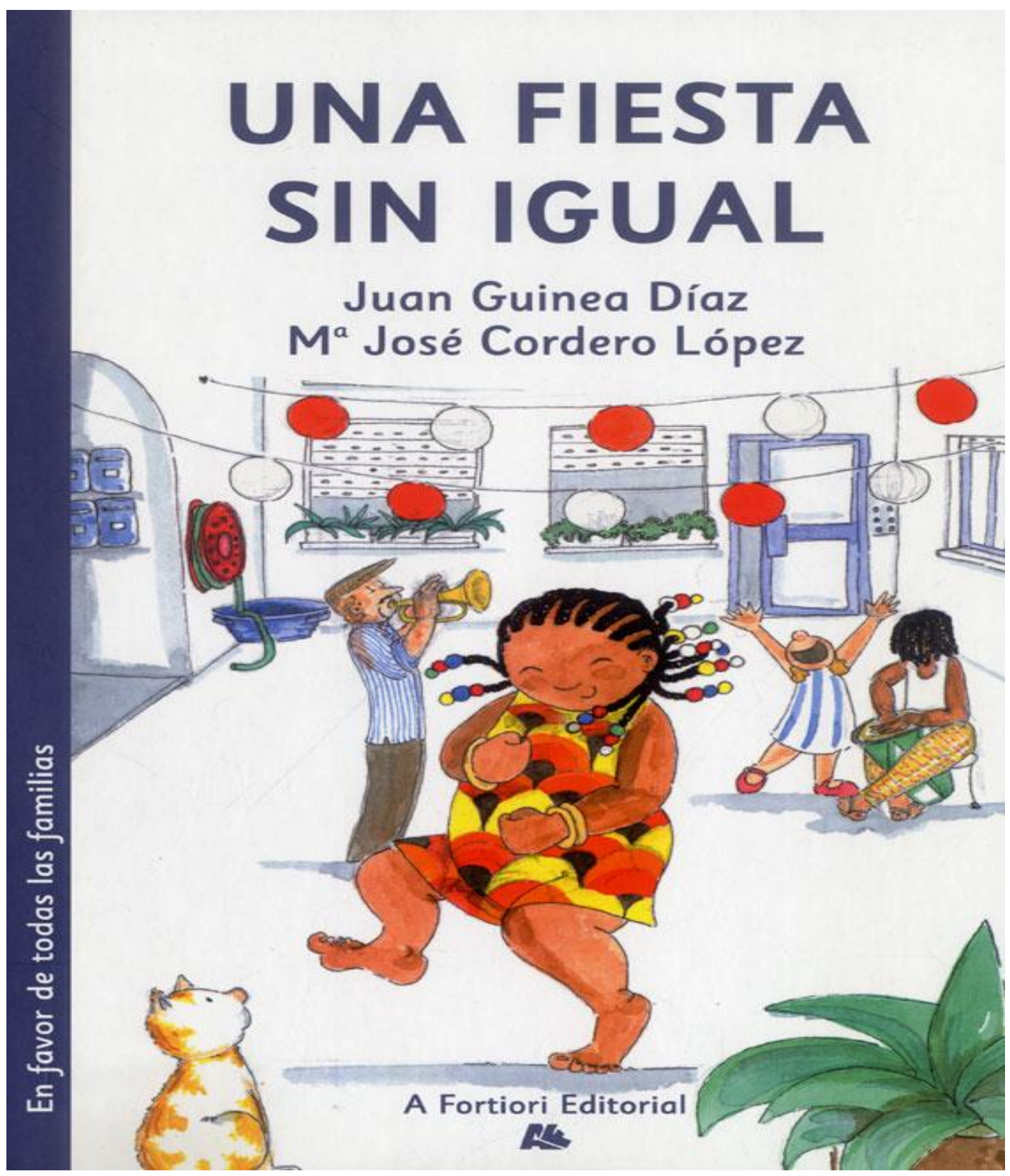

Díaz Guinea, Juan y Cordero López María José. Una fiesta sin igual. Bilbao: A Fortiori Editorial, (1 $1^{\text {a }}$ ed.) septiembre de 2011 
- El libro está recomendado para niños y niñas de seis años. La obra cuenta la historia de una niña africana que vive con su abuela, madre y hermano, en un vecindario con una variedad de construcciones familiares, con diferentes estatus sociales, distintas etnias, culturas, tradiciones, en definitiva, cada uno ha formado una familia muy diferente de las otras, pero todas iguales de felices y construidas bajo la tolerancia y el respeto.

Cuenta como todas los personajes están entusiasmados con la fiesta de bienvenida que van a dar al nuevo vecindario, y como cada familia aporta algo de su particular cultura, ya sea comida, actividades, música, disfraces, y todos y todas se respetan mutuamente.

- El libro presenta una estructura narrativa basada en la consecución de los hechos, es decir, el personaje se limita a contar lo que está sucediendo ordenando los elementos de todo tipo como personajes, acciones o lugares. Relata un día de su vida con un principio y un final, detallando cada situación que acontece. Mantiene la misma estructura expuesta anteriormente, ya que la historia comienza con una situación inicial, donde se presenta a los personajes, después le sigue el conflicto, en el que los personajes, puesto que van a realizar una fiesta, se centran en una acción determinada hasta que finalmente se resuelve el nudo o entramado de la historia, realizando la fiesta de bienvenida entre todo el vecindario, con lo que la situación final es distinta a la inicial. Teniendo en cuenta que el personaje principal es una niña, es ella la que narra en primera persona lo que hace y lo que está sucediendo, por tanto según la metodología de escogida, la obra presenta un discurso contado o narrativizado, basándose en primera persona para relatar la historia.

- Lo más interesante es como los autores del cuento es la visión de multiculturalidad que muestra, como propia de todas las sociedades, bajo un texto fácil 
de leer y de entender para niños y niñas de infantil, a la vez que mezclan una variedad de imágenes cargadas de rasgos y valores positivos, mientras que los niños y niñas interactúan con los personajes, empleando la poesía en su texto. Por multiculturalidad me refiero a la diversidad de grupos étnicos que aparecen en el relato, con sus respectivas culturas y perspectivas de comprender y visualizar el mundo. Como Rosa Cobo sostiene: el multiculturalismo, entendido como una manifestación de la diversidad, del pluralismo cultural y de la presencia en una misma sociedad de grupos con diferentes códigos culturales, no es una condición singular de la cultura moderna, es la condición normal de toda cultura ${ }^{106}$.

Bajo esta percepción, el multiculturalismo que el cuento ofrece se entiende como una sociedad en la que coexisten diversos grupos con identidades culturales propias, enriqueciéndose mutuamente.

La protagonista comienza relatando las personas que habitan en su vecindario, en el segundo piso vive una pareja homosexual compuesta por dos varones que se encargan de hacer las invitaciones de la fiesta y representaran un tango porque uno de ellos es argentino. En la planta baja vive una niña que tiene una silla de ruedas y todos y todas van a hacer una carrera en esa silla de ruedas para divertirse, a la vez que interactuaran con ella para comprobar cómo se vive necesitando este apoyo y no poder caminar. Otra familia está compuesta por una madre soltera que fue a Asia para adoptar a una niña china y participarán en la fiesta llevando comida asiática. En el tercero vive una pareja considerada de la tercera edad, hombre y mujer, que comparten los quehaceres de la vida y se entienden a la perfección en la cocina. También cuenta cómo otra familia que es de marruecos van a preparar la comida típica de su país a la vez que

\footnotetext{
${ }^{106}$ Cobo, Rosa. “Multiculturalismo, Democracia Paritaria y Participación Política”. Madrid: Política y
} Sociedad, no 32, 1999, pp. 1 
relatan sus historias. Aparece una mujer que es artista y que tiene unos sesenta años, y que realizará una actuación con sus tacones y su vestido. Nos cuenta la historia de una familia que es vegetariana y el marido se encarga de hacer la comida diariamente y una mujer que vive con sus catorce gatos. En el quinto habita una madre soltera con su bebe y la imagen muestra a la mujer amamantando al niño o niña.

El resto de familias también pertenecen a otros países con sus propias culturas, pero la lección final que nos quiere mostrar el cuento, es que no importa el estatus social, el sexo, las relaciones ni construcciones familiares, la cultura, la orientación sexual, las etnias, la edad sino la tolerancia, la igualdad y el respeto que tienen entre todos y todas. Se ve como las categorías de los nuevos valores emergentes y la resolución de conflictos quedan reflejadas en la historia. El relato muestra la posibilidad de convivir en paz y tolerancia entre distintas culturas, distintos sexos, en definitiva distintos tipos de personas, bajo el respeto, la tolerancia, la convivencia, la amistad, la solidaridad. Se apuesta por una convivencia pacífica bajo la presencia de valores coeducativos mostrando la diversidad cultural como un hecho positivo y enriquecedor.

Considero que la obra representa valores coeducativos porque parte de la igualdad y toleración bajo el respeto a los demás individuos, sin importar las cualidades personales o sociales que puedan presentar. Se sustenta bajo una igualdad de género, donde los personajes conviven sin prejuicios ni estereotipos. Nos muestra el privilegio de convivir con otras culturas por el aprendizaje que ello conlleva y a su vez la armonía que todos y todas muestran cuando interactúan entre sí, participando íntegramente en las actividades para aprender aspectos de otras culturas. En este relato deja constancia que las familias son construcciones sociales y no necesariamente tiene que existir un vínculo de consanguineidad, tan sólo una relación afectiva creada bajo la igualdad, respeto y amor. 
Resulta llamativo el titulo del cuento, Una fiesta sin igual, porque es un juego de palabras donde indica que ningún personaje posee algo igual, al contrario, son muy diferentes entre sí, pero parten de la igualdad como personas, independientemente de su diversidad, respetándose entre todos y todas al margen de los prejuicios que posee cada cultura. Es una crítica a la familia tradición heterosexual y nos enseña una vez más que debemos redefinir el concepto de familia, porque una familia es el lugar de convivencia y lazos afectivos con otras personas sin necesidad de existir una relación de sangre.

- Para el análisis de imagen puedo constatar que, el libro representa de manera muy visible la vida y costumbres de cada personaje, por ejemplo, cuando habla de la homosexualidad representa a los dos compañeros bailando juntos (imagen 1), o la maternidad a través de la madre soltera dando de amamantar a su bebe (imagen 2), es decir, no deja nada a la imaginación porque representa a la perfección lo que relata a través del texto y permite generar una idea global y detallada de los acontecimientos que van sucediendo. Como valor emergente, vemos en la "imagen 1" la homosexualidad como algo natural y común en la sociedad, y la "imagen 2" constituye un valor tradicional porque representa la maternidad como siempre se ha mostrado, con la madre dando de amamantar a su bebe, esta imagen prototípica de la maternidad, puede reflejarse también a través de la figura de un varón, no necesariamente siendo la madre la que ejerza esta acción. 


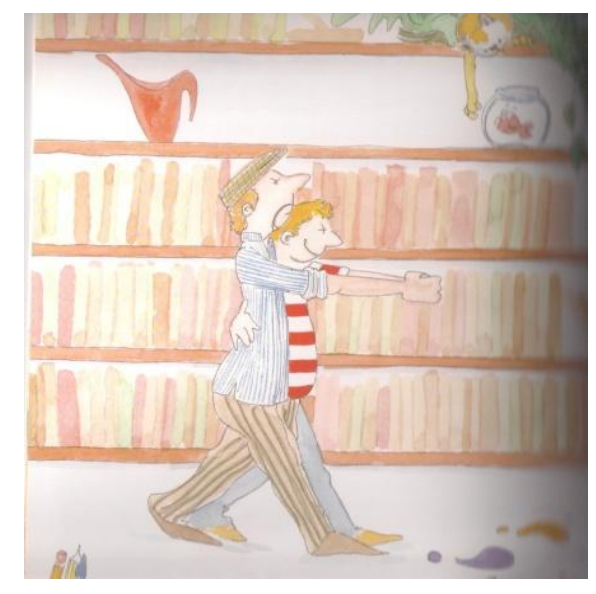

Imagen 1

Fuente: Cordero López, Ma José. En Una fiesta sin igual, 2011, pp. 3

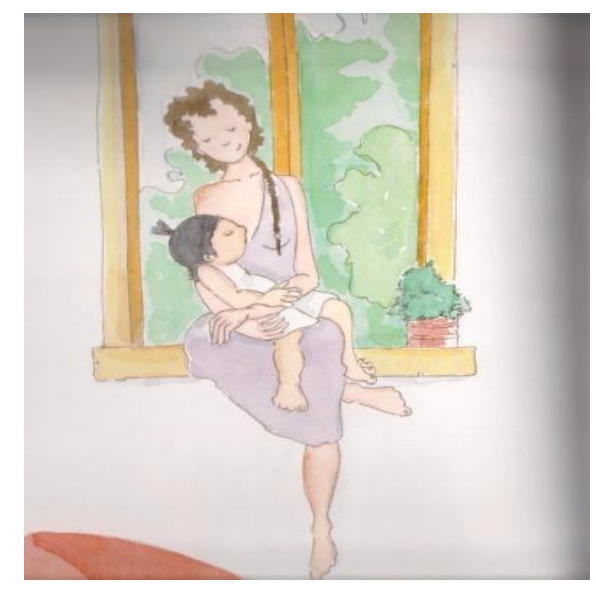

Imagen 2

Fuente: Cordero López, Ma José. En Una fiesta ..., obra citada, pp. 19

Las imágenes están acompañadas de un texto rimado que da un toque de musicalidad facilitando la lectura al niño o la niña y la hace más amena y divertida, a la vez que intenta que el lector o lectora, interactúe con la obra a través de juegos, como la búsqueda de animales en sus páginas. 


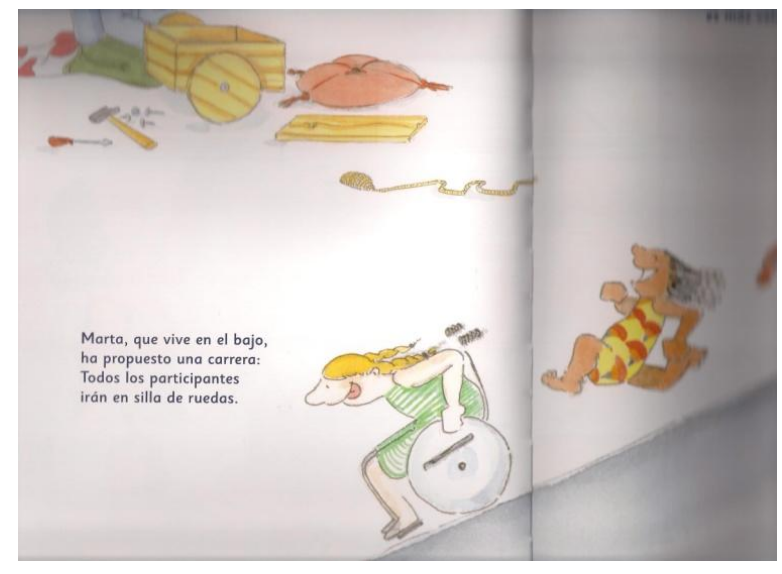

Imagen 3

Fuente: Cordero López, Ma José. En Una fiesta ..., obra citada, pp. 5-6

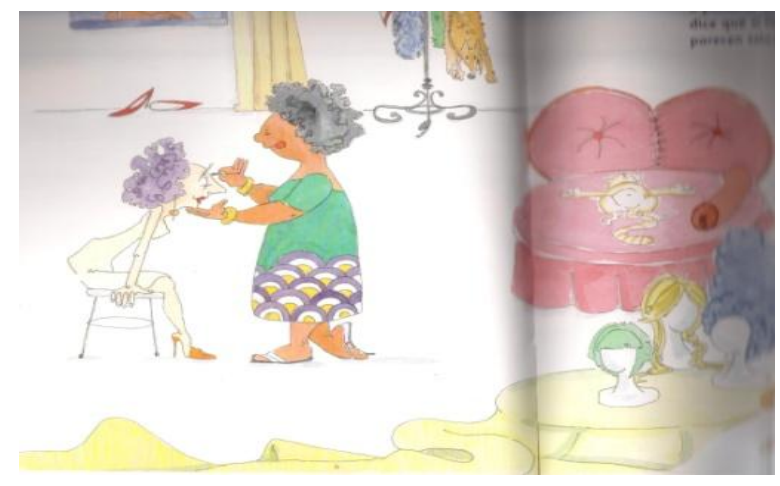

Imagen 4

Fuente: Cordero López, Ma José. En Una fiesta ..., obra citada, pp. 13-14

Todas las imágenes representan la vida real y se acercan a la realidad de nuestra sociedad, una sociedad multicultural y diversa, con distintas razas, etnias, sexos, en definitiva, distintos modos de vida y costumbres culturales. Se percibe la discapacidad física como un valor positivo en el que la niña, en este caso, puede divertirse y realizar las mismas acciones que el personaje principal, sin ocasionarle ningún impedimento el necesitar una silla de ruedas (imagen3), o como se percibe en la "imagen 4", la mujer 
mayor sigue ejerciendo de cantante y artista, con sus tacones y vestidos, sin importar la edad.

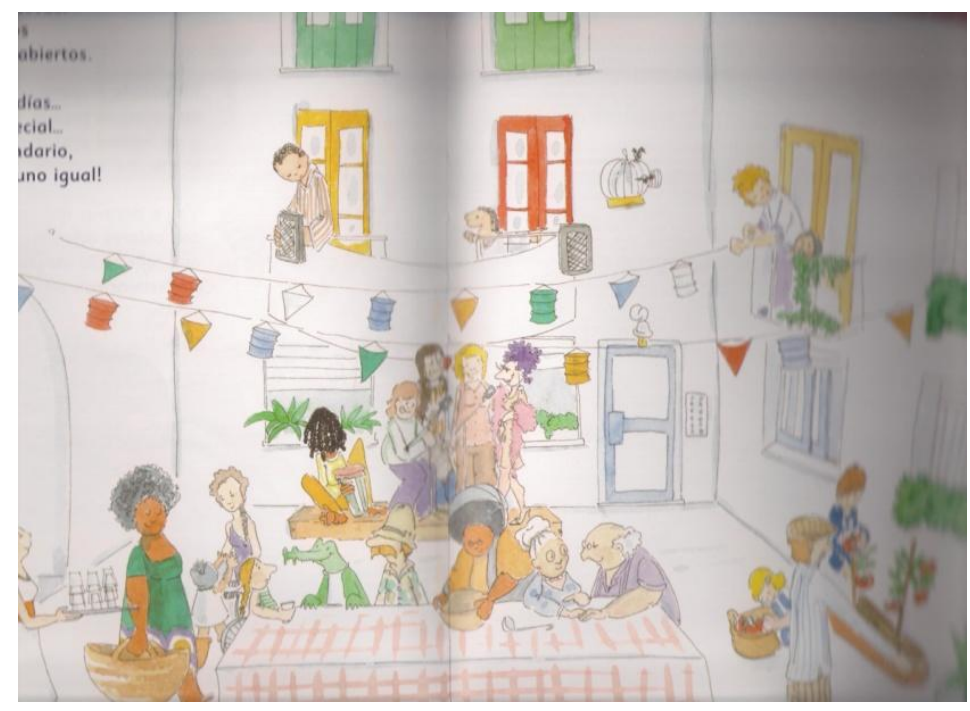

Imagen 5

Fuente: Cordero López, Ma José. En Una fiesta ..., obra citada, pp. 29-30

En la "imagen 5" se muestra todo lo expuesto anteriormente, cómo los personajes interactúan y conviven bajo la paz, tolerancia y el respeto entre ellos y ellas, adquiriendo lo positivo de sus formas de vida y comportamientos propios de cada cultura, conviviendo bajo la diversidad proporcionando autonomía y respeto para cada persona. Este libro presenta aspectos coeducativos porque además de todo lo dicho, representa la variedad de familias que existen al margen de la familia tradicional que ha existido siempre. 


\section{3.- Las tres mellizas hacen las paces}

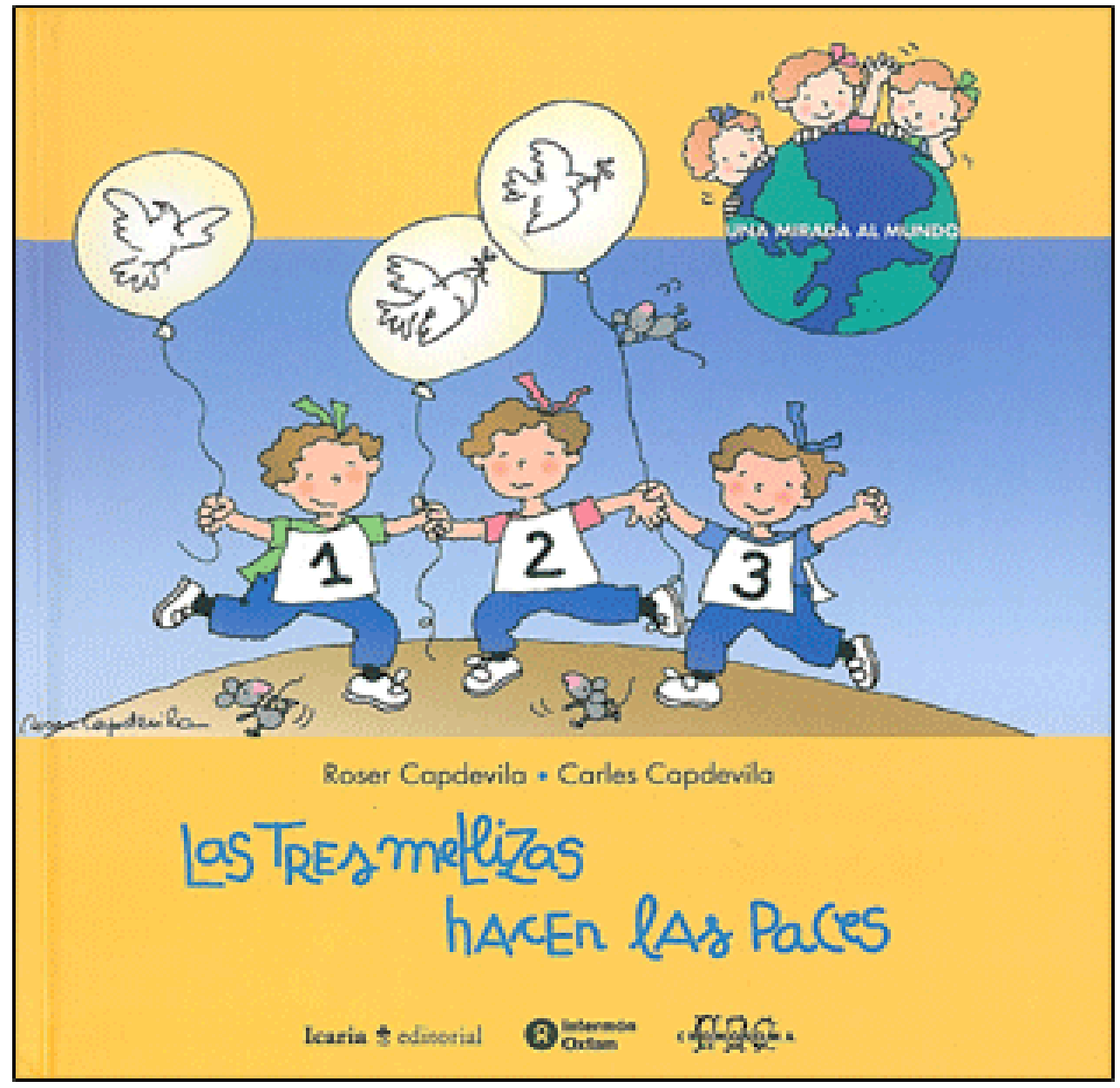

Capdevila, Roser y Capdevila, Carles. "Las tres mellizas hacen las paces" Madrid: Icaria editorial. ( $1^{\mathrm{a}}$ ed.) 2001 
- Esta obra, recomendada para niñas y niños de cero a cinco años. Comienza relatando un día en la vida de las tres mellizas, que se ven inmersas en un conflicto personal y tienen que poner solución. Las tres mellizas (Ana, Teresa y Elena) se encuentran en el colegio y un amigo común de ellas se acerca, para comentarles que va a realizar una fiesta de cumpleaños. David, el cumpleañero, tan sólo puede invitar a diez personas y tiene el cupo de invitación lleno, sólo le queda sitio para una de ellas. Cuando las hermanas se enteran de esto, comienzan a pelearse entre ellas intentando disputarse la única invitación para el esperado cumpleaños. La profesora les enseña que deben hablar y no pelearse, porque las cosas se arreglan hablando, pero de repente aparece la "Bruja Aburrida" y las envía a un concurso llamado, "Aquí, todo vale”. En este concurso tienen que luchar y competir para llegar a la final, pero la envidia les corroe y comienzan a hacer trampas entre las tres, intentando cada una de ellas, llegar a la final mediante "juego sucio". Finalmente Teresa llega a la final y tiene que competir con un niño. Ana y Elena hablan con ella para convencerla de que han sido estúpidas por luchar presionadas por la envidia y las trampas, que se aparte de la final y hagan las paces, a lo que Teresa se niega y decide continuar. En la final Teresa tiene problemas y sus hermanas le ayudan y consiguen salvarla y es entonces cuando comprenden que cuando hay problemas, se deben solucionar mediante la palabra, nunca mediante la fuerza y la violencia.

- El relato presenta una estructura narrativa donde se refleja claramente una situación inicial, en la que las hermanas se divierten en clase; después comienza el detonante del conflicto cuando se enteran de que sólo una de ellas ha sido invitada a la fiesta de cumpleaños de David, surge entonces la envidia entre las tres y se da el conflicto peleándose y discutiendo para conseguir esa invitación, tras entrar en el concurso y darse cuenta de que la situación ha empeorado comienzan a buscar 
soluciones y finalmente la resuelven haciendo las paces, pidiéndose perdón y abrazándose.

- Esta obra presenta en su análisis lingüístico la forma común de los relatos infantiles, el discurso restituido o directo, ya que el narrador o narradora cuenta los hechos pero da paso a los personajes, para que ellos mismos interpreten la situación y hablen en primera persona, así da un efecto de autenticidad y cercanía, consiguiendo que el receptor sea partícipe de la obra, dando más veracidad a la historia que presenta.

- Centrándome en el análisis del discurso y siguiendo la metodología escogida junto con las tres categorías de análisis, la obra presenta claramente un tema principal, la resolución de conflictos mediante el consenso, la pablara y el pacifismo. Las tres mellizas tras comprobar que la lucha, la disputa y las peleas no les lleva a ninguna parte, se conciencian de que los problemas se solucionan hablando y no discutiendo o mediante la violencia. La Bruja ha puesto a prueba a las tres hermanas y ante la situación de ver en peligro a una de ellas, han unido sus fuerzas y sus conocimientos para salvarla.

Esta situación anima a los más pequeños y pequeñas, a resolver los problemas de manera pacífica, a la vez que se valora el amor y la amistad entre las propias hermanas. Considero importante que la obra realce el tema de la competitividad puesto que convivimos en una sociedad en la que constantemente tenemos que luchar y competir para conseguir el mejor estatus académico o laboral porque el sistema así lo exige, por ello estimo que esta obra presenta aspectos coeducativos en la medida que enseña los valores de competitividad pero desde una posición pacífica, y muestra que trabajar en equipo es satisfactorio porque se aprende bastante de los otros, además de poder conseguir muchas más soluciones a los problemas que aparezcan. 
Con respecto a la igualdad de género, he percibido que tanto niños como niñas interactúan juntos sin ningún problema y sin estereotipos de género asociados, puesto que al comienzo del libro, éste presenta a las tres hermanas peleándose con empujones y patadas, algo que nos sugiere más propio del género masculino (ya que se considera que las niñas no luchan). Lo que quiero mostrar con este aspecto es que la obra destaca el valor de la fuerza y la lucha como algo que puede darse tanto en niñas como en niños, pero que pueda representarse en ambos sexos no implica que sean valores coeducativos, porque la lucha mediante la violencia no es un elemento coeducativo a destacar en un cuento infantil.

Un dato importante con respecto a la igualdad de género es que la competitividad es mostrada tanto en niñas como en niños, se aplica la fuerza tanto a ellas como a ellos. Al finalizar el cuento, cuando relata la situación de la fiesta de cumpleaños, los autores señalan que la madre de David permite que un amigo o amiga suya puedan pasar la noche, el texto deja claro que no importa si es niño o niña, cuando siempre se nos ha acostumbrado a relacionarnos más con nuestro grupo de iguales, los niños con los niños y las niñas con las niñas.

Con respecto a los valores emergentes y tradicionales, compruebo que este libro destaca como valor emergente la posibilidad de que todos los niños y niñas jueguen juntos sin importar el juego, es decir, da igual que estén jugando al futbol, a la comba, a las canicas, etcétera, ningún juego está identificado a un sexo determinado, de hecho se puede comprobar cómo las tres mellizas mantienen una actitud igual que la de los niños frente a las situaciones y acontecimientos que se plantean, no diferencia en función del sexo, por ejemplo, cuando muestran las peleas, en este caso representan a las tres niñas peleándose, mostrando la realidad, que ellas pueden pelear también, al igual que ellos. Además el cuento muestra la importancia del compañerismo y las relaciones sociales 
entre todas las personas sin importar el sexo o la etnia, de hecho aparecen todos los niños y niñas en el patio de recreo y claramente se observan personas de distintas culturas.

Con respecto a valores tradicionales, el libro representa a la bruja de forma estereotipada, como las brujas que aparecen en la mayoría de cuentos tradicionales. Este personaje suele ser malvado e intenta perjudicar a los demás, pero en este caso, a pesar de mostrar el estereotipo de bruja, también lo percibo como aquellas circunstancias que aparecen en nuestro día a día y nos ponen a prueba, dando lugar a que tengamos que enfrentarnos a situaciones de esta dimensión.

- A través del análisis de imagen puedo percibir estos valores de multiculturalidad, donde niños $y$ niñas se divierten juntos intercambiando $y$ compartiendo juguetes.

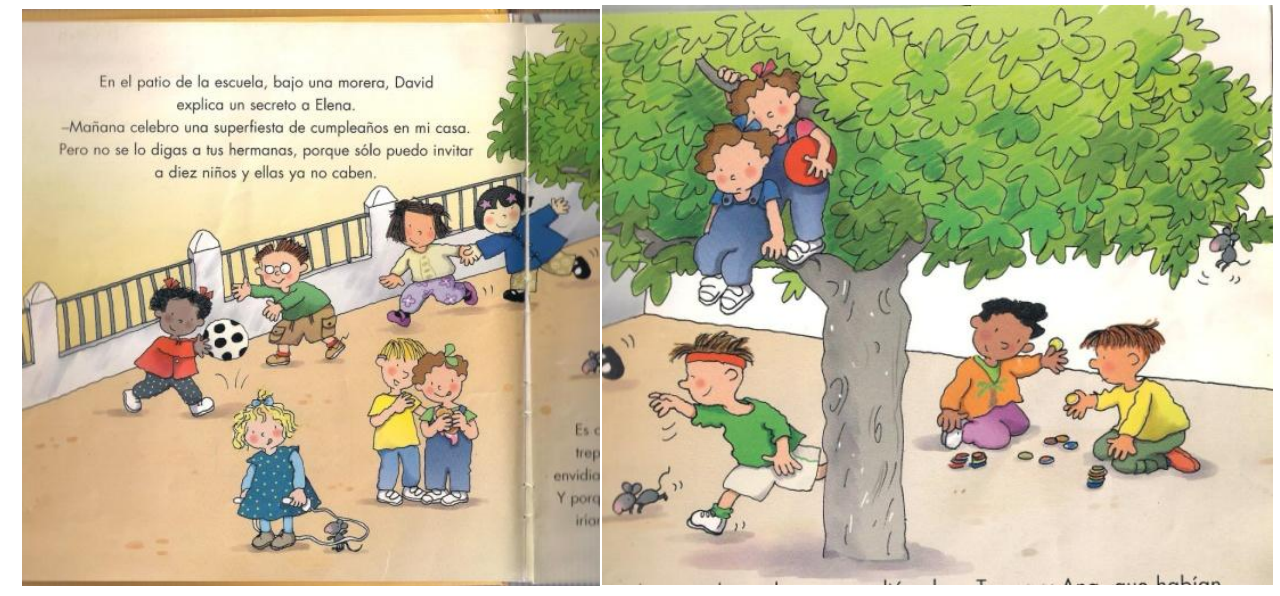

Imagen 1

Fuente: Capdevila, Roser. En Las tres mellizas hacen las paces, 2001, pp. 1-2 
La representación de las diferentes culturas sólo se percibe a través de la imagen ya que el texto no se refiere en ningún momento a este dato, también se puede observar el compañerismo entre todos los niños y niñas y cómo ambos interactúan juntos.

Es llamativa la imagen donde las tres mellizas se pelean y es el niño el que mira sorprendido, cuando es común representar a los niños en medio de disputas y las niñas mantenerse al margen por entenderse que ellas no luchan y son débiles.

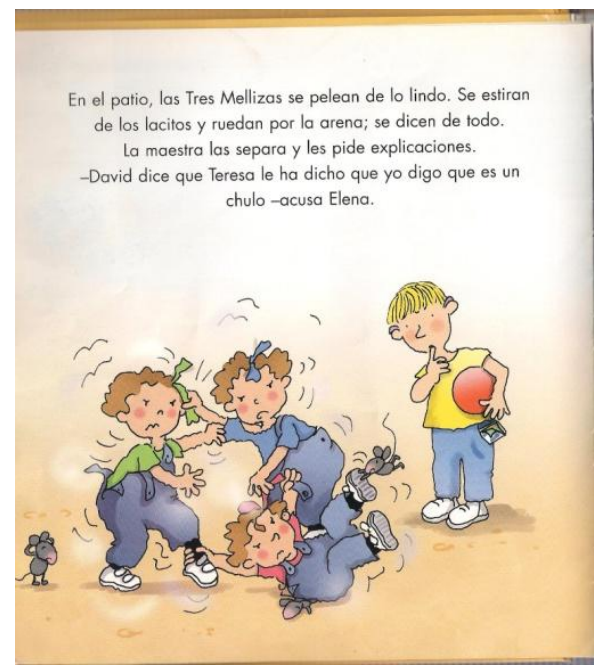

Imagen 2

Fuente: Capdevila, Roser. En Las tres mellizas ..., obra citada, pp. 7

Resulta importante destacar la vestimenta que llevan las tres hermanas, puesto que no son representadas a través de vestidos o faldas, es decir las prendas consideradas típicas del sexo femenino, al contrario se presentan con pantalones y zapatillas para poder saltar, brincar, caer y jugar sin limitaciones. 


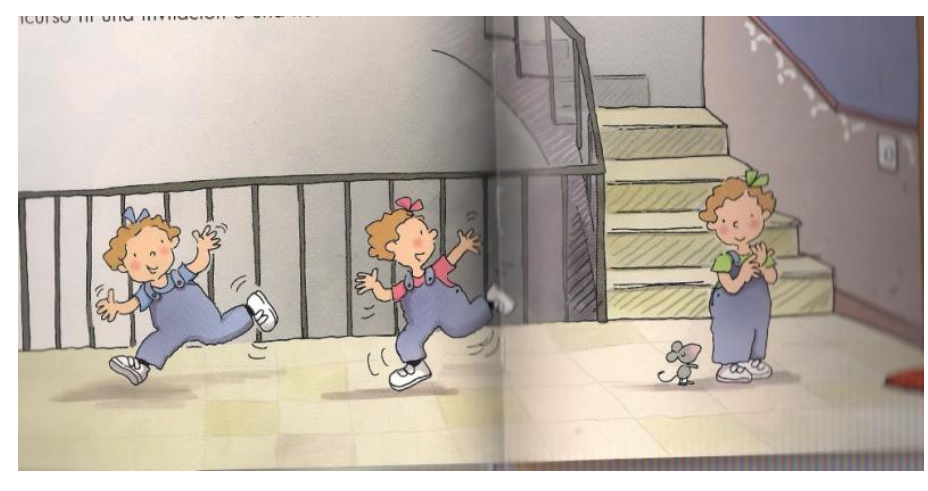

Imagen 3

Fuente: Capdevila, Roser. En Las tres mellizas..., obra citada, pp. 29-30

Finalmente, tanto la imagen como el texto, representa cómo es posible llegar a un acuerdo sin la violencia. Las tres hermanas han puesto solución a sus problemas y mientras que Elena se divierte en la fiesta, Teresa y Ana van a visitar a otra amiga. Deciden que la envidia y los celos no son buenos puesto que sacan lo peor de cada persona y prometen que nunca más se van a pelear, ni por una fiesta de cumpleaños, ni por un concurso. Es importante reflejar tales aspectos coeducativos en los libros de texto, ya que estas situaciones suelen darse con asiduidad en la etapa de educación infantil. 


\section{4.- Una mamá para Owen}

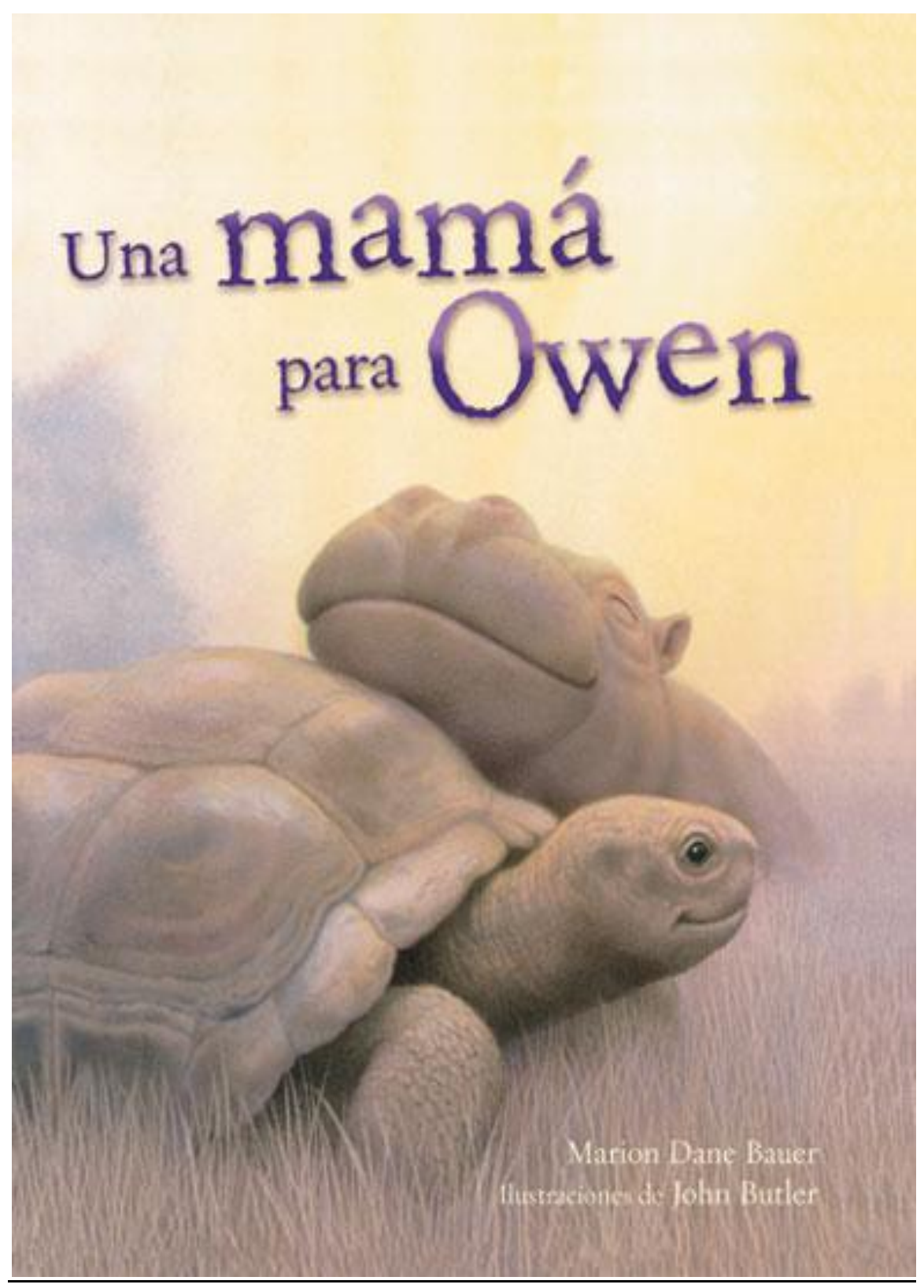

Dane Bauer, Marion y Butler, John. "Una mamá para Owen” Barcelona: RBA Libros, S.A. (1 ${ }^{\text {a }}$ ed.) septiembre de 2007 
- Este precioso relato, recomendado para un público de cero a cinco años, cuenta la historia de una familia de hipopótamos que habita en las tierras africanas, cuyo protagonista es un hipopótamo varón llamado Owen, de poca edad, que se divierte con sus amigos y familiares en la costa del río Sabaki. Owen siempre está junto a su mamá, y pasan el día jugando, escondiéndose y durmiendo juntos, a Owen le encanta estar cerca de su mamá. Una noche de tempestad en la que el tiempo es horrible y no para de llover, provoca que el caudal del río crezca tanto que llega a desbordarse y Owen y su familia son arrastrados hasta el mar. Owen llama a su mamá y a su familia pero no encuentra a nadie, se ha perdido y está solo en aquel nuevo lugar. De repente ve de lejos algo que se parece a su mamá, porque es marrón y gris y camina hacia allí para acurrucarse a su lado. Este animal no es un hipopótamo, sino que es una tortuga macho de 130 años llamada Mzee, pero a pesar de no ser su mamá, ni ser el mismo animal que él, se convierten en madre e hijo, y Mzee hace el papel de la madre que Owen tanto añora y necesita. Juntos juegan, comen, caminan y duermen, Owen siente que ella es su madre.

- La obra presenta una estructura como las anteriores, donde claramente se percibe cual es la situación inicial en la que Owen disfruta y convive con sus familiares, más tarde empieza la fase del conflicto, donde el tiempo empeora y todos se ven arrastrados por el río hasta el mar, la frustración de Owen al sentirse solo y sin nadie a su alrededor, hasta que se encuentra con la tortuga y conviven felizmente, siendo esta la situación final de la estructura. Toda la obra es relatada por el propio narrador o narradora contando en tercera persona lo que dicen los personajes, de manera que puede manipular sus palabras, esta estructura se ajusta al discurso contando o narrativizado.

- Para el análisis de contenido y centrándome en la metodología escogida, compruebo en el cuento infantil la importancia que el autor establece entre el vínculo 
social y personal, el pequeño hipopótamo posee un vínculo muy estrecho con la madre y con todo lo que le rodea, la naturaleza y todos los demás animales que conviven con él. Se observa cómo se encuentra ante una difícil situación en la que pierde a su familia y amigos, se aleja de su hábitat y se encuentra solo, en medio de un conflicto personal al que tiene que poner solución. Lo más llamativo del relato es cómo un animal distinto al suyo hace de madre para él, y con distinto sexo, considero que es aquí donde puedo centrar mi análisis aplicando las tres categorías que he desarrollado en la parte de análisis de contenido.

Por un lado, la obra resuelve satisfactoriamente el conflicto en el que Owen se encuentra, construyendo una nueva familia bien distinta a la suya biológica, esta familia sólo está compuesta por un sujeto, que además es macho por lo que intercambian los estereotipos de machos o hembras, ya que se entrevé como esta tortuga macho hace de mamá para Owen, y no de papá. A la vez, este hecho puede interpretarse como un valor emergente que la autora ha querido emplear en su obra, ya que podríamos pensar que puesto que él ha perdido el vínculo con su mamá, lo va a encontrar en otra hembra, y finalmente lo encuentra en un macho.

Este relato rompe totalmente con los estereotipos sexuales, porque la tortuga varón toma el papel de "madre", y así lo menciona la autora en el libro; se intercambia el rol femenino y masculino indistintivamente. El relato también rompe con la tradicional familia heterosexual, compuesta por varón-mujer, macho-hembra, aunque al principio Owen dispusiese de una familia compuesta por padre y madre, finalmente su familia acaba conformada por un sujeto y es macho, lo que demuestra que las relaciones afectivas entre familiares no necesariamente van ligadas a las relaciones de consanguineidad, una tortuga macho de ciento treinta años puede hacer el papel de madre que Owen necesita para su desarrollo personal, puesto que los hipopótamos 
necesitan convivir con sus madres hasta los cuatro años, de hecho al final de la historia, la autora relata que este acontecimiento ocurrió en la realidad, y que el hipopótamo con sólo un año fue llevado al Haller Park, una reserva natural de Mombasa donde éste y la tortuga establecieron relación de madre-hijo.

Las imágenes más significativas de la obra son aquellas en las que el hipopótamo es representado junto a la tortuga. Prácticamente casi todas las imágenes muestran un lado de dulzura en la que se perciben roces, abrazos, caricias, convivencia pacífica junto a otros animales, amor, etcétera.

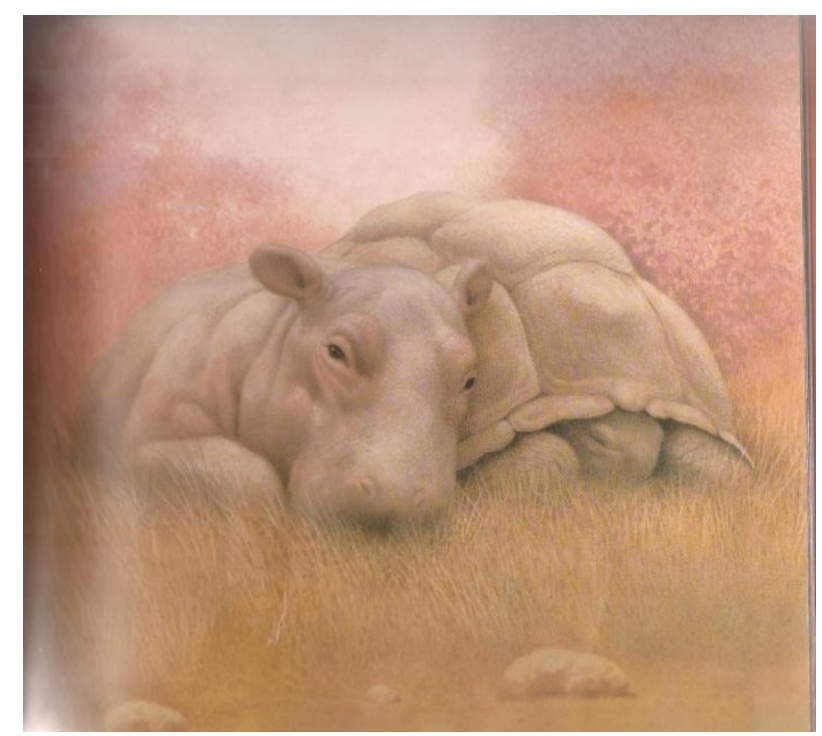

Imagen 1

Fuente: Butler, John. En Una mamá para Owen, 2007, pp. 16 


\section{5.- Inés tres pies}

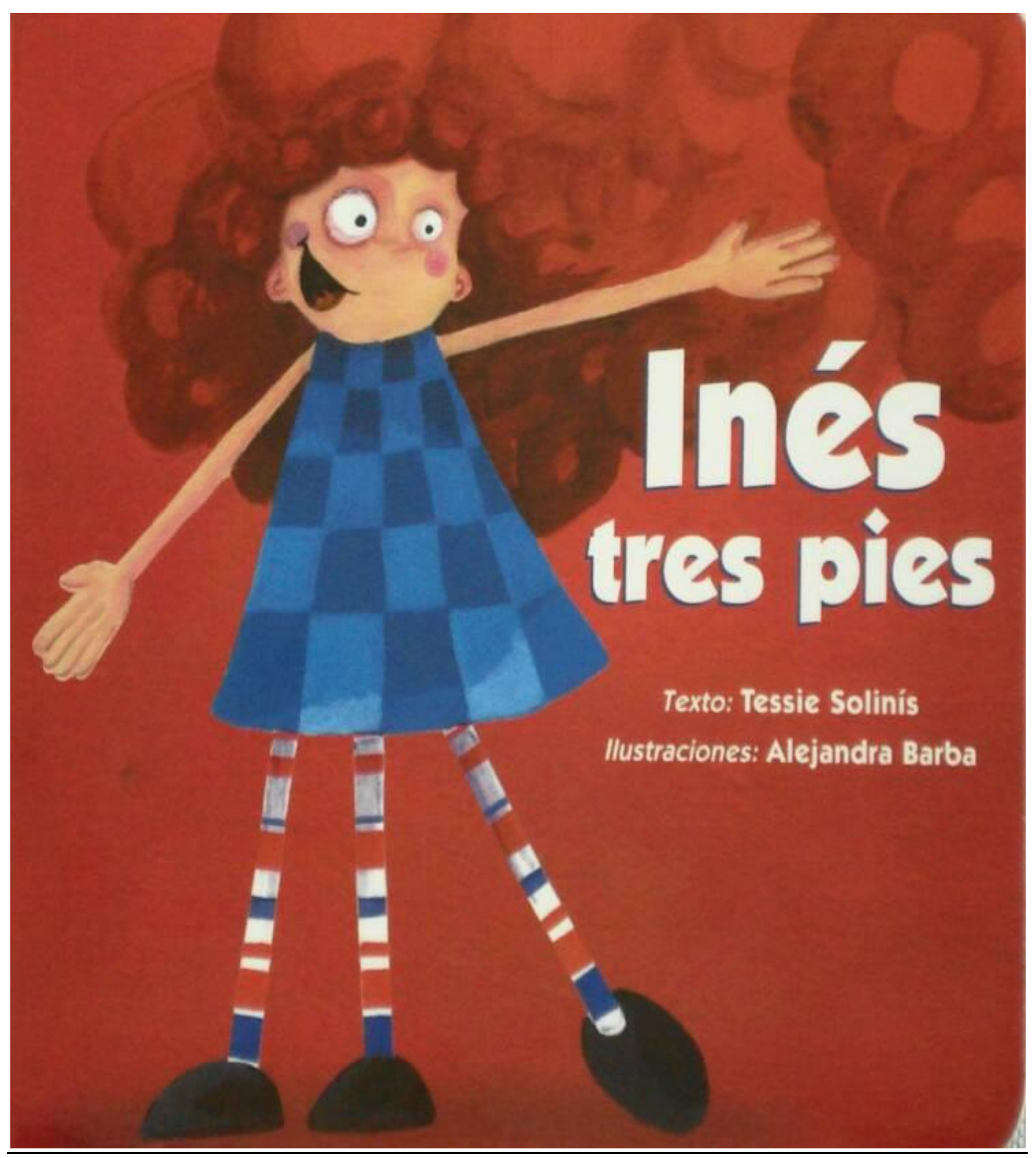

Solinís, Tessie y Barba, Alejandra. "Inés Tres pies”, México: CIDCLI,S.C. (1 $1^{\mathrm{a}}$ ed.) marzo de 2004 
- Este libro está dedicado especialmente a niños y niñas de hasta cuatro años. El tema principal del relato es: la discapacidad física, ya que el argumento del cuento se centra en Inés, una niña que tiene tres pies, y va contando todas las actividades que puede realizar a lo largo del día con sus tres pies, ella puede ser veloz al correr, jugar a la pelota con seguridad, a la vez que bailar muy bien. Asegura que le encanta pintarse las 15 uñas de los pies y se divierte colocándose zapatos de distintos colores y estilos. Un día se plantea la idea de cómo sería su vida si no tuviera tres pies y sólo tuviera dos, uno o ninguno, pero finalmente ella está feliz con su situación personal y con sus tres pies.

- Se percibe una estructura narrativa con una situación inicial estable, en la que el personaje se presenta y relata todas las acciones que ésta puede realizar gracias a sus tres pies, más tarde empieza la fase del conflicto o nudo donde ella se cuestiona que pasaría si no tuviese esos tres pies, y si sólo tuviese uno o dos, hasta que finalmente se resuelve dicha acción y la situación vuelve a ser estable. El narrador o narradora relatan la historia en tercera persona, en ningún momento cede la palabra al personaje principal y se encarga de contar los acontecimientos que le van surgiendo al personaje, por tanto el relato presenta un discurso contando o narrativizado.

- Para el análisis del discurso y acotándome a las categorías empleadas, el personaje del cuento, Inés, se encuentra ante un conflicto personal en el que se cuestiona que ocurriría si su vida no fuese así, y le faltase alguna pierna, si podría ejercer su vida con "normalidad", lo que para ella considera que es "normal" o si tendría algún impedimento o dificultad para su día a día. Considero importante que representen el tema de la discapacidad física desde un lado tan "natural" y sencillo mostrando a un personaje que ha nacido así y puede realizar cualquier actividad y mantener una vida real sin ningún problema ni limitación, y poder ver el mundo bajo su situación y 
perspectiva personal. Con frecuencia mostramos a los más pequeños y pequeñas, lo que para nosotros y nosotras consideramos que es la normalidad; normalidad no es tener dos pies y dos brazos, la normalidad es muy relativa porque está marcada por unas normas sociales y culturales. Lo que en la sociedad occidental puede ser normal, en la oriental puede ser lo más extraño y atípico del mundo, por ello el libro presenta aspectos coeducativos con respecto a los valores considerados normales bajo una perspectiva social determinada.

Comienza explicando la cantidad de acciones que puede realizar gracias a que tiene tres pies, y su problema radica cuando se plantea la hipótesis de que pasaría si no tuviera tres pies, y tuviera sólo dos, al igual que nosotros y nosotras podemos preguntarnos cómo podríamos vivir con tan sólo una pierna. El lector o la lectora puede percibir un problema al tener tres pies, pero el cuento lo muestra cómo una ventaja ya que puede jugar, saltar y correr más rápido que aquella persona que tiene sólo dos, muestra de una manera muy visible que la mayoría de las personas están equivocadas al ceñirse a la idea de que una vida perfecta y normal es aquella en la que el sujeto dispone de todos sus miembros corporales, y como refleja el libro, el personaje está feliz por tener esa situación personal, bien distinta, a los demás.

En la categoría de Igualdad de género, compruebo que las autoras no hacen distinción con respecto al sexo al representar las acciones que Inés realiza en su día a día, puede verse como ella juega al futbol, corre, usa patines, baila, acciones que normalmente se asocian a un género o a otro, en esta obra la protagonista juega y realiza cualquier acción, al igual que tampoco es representada con colores que tradicionalmente se asocian a las niñas o a las niñas, en este caso Inés viste y usa toda la gama de colores, de hecho lleva un vestido azul. Tan sólo puede comprobarse cómo ella se divierte pintándose las 15 uñas, hecho que designaríamos como propio del sexo femenino, pero 
del mismo modo juega al futbol, más relacionado con el sexo masculino, por tanto queda visible como ni su discapacidad física ni su sexo le impiden realizar ninguna acción.

Como valor emergente y nuevo destaco la manera en cómo las autoras representan el tema de la discapacidad física a través del personaje Inés con tres pies, lo reflejan como positivo, en ningún momento muestra limitaciones o representa su disposición personal como obstáculo para hacer lo que ella desee, al contrario, muestran al personaje con sus tres pies como un hecho "normal" para ella, puesto que siempre ha convivido con los tres pies y forman parte de ella. Lo llamativo es que este libro está dedicado a niños muy pequeños, y resulta importante trabajar estos valores desde un lenguaje muy sencillo y familiar, de manera que los pequeños asimilen los conceptos importantes e interioricen las diferencias personales como un hecho positivo, sin prejuicios ni desigualdades.

- Con respecto al análisis de imagen, la ilustradora ha mostrado al personaje en su día a día realizando actividades como cualquier otro niño o niña, corriendo, saltando, patinando, bailando, dejando claro que tener tres pies, como en este caso, no le impide poder divertirse como el resto de personas, de hecho destaca esta circunstancia como una virtud y ventaja con respecto a las demás niñas o niños. 


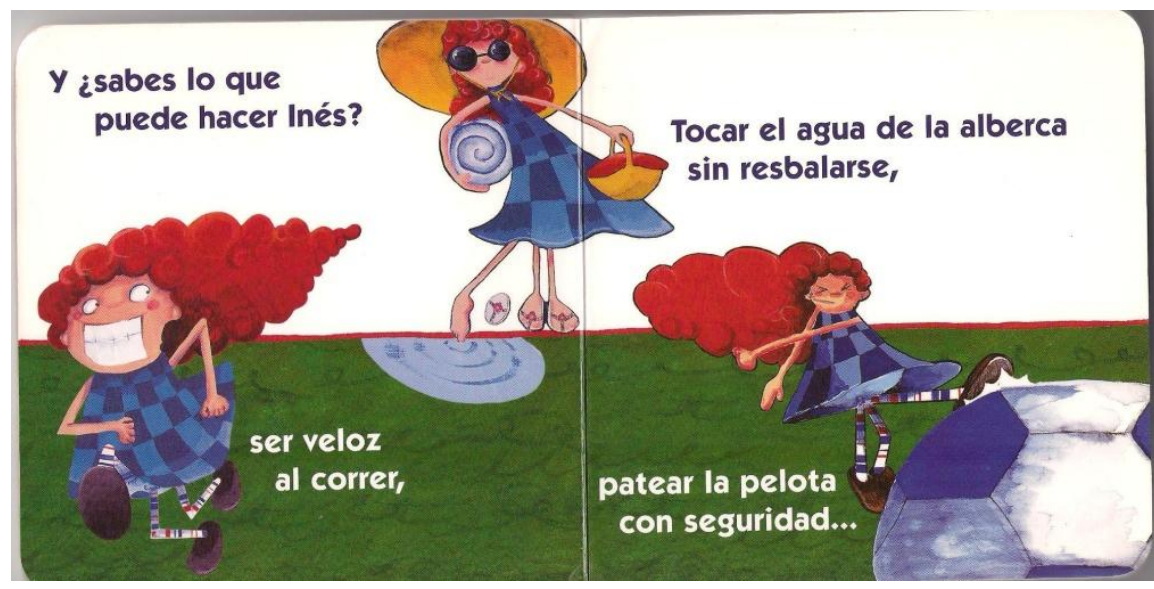

Imagen 1

Fuente: Barba, Alejandra. En Inés tres pies, 2004, pp. 5-6

Puedo concluir diciendo que este libro muestra valores coeducativos, en la manera de representar la discapacidad física, de una forma tan natural y fácil de captar y entender por los niños y niñas de educación infantil. Considero importante destacar cómo el libro deconstruye el concepto de "normalidad", qué entendemos por "normal" y qué queda fuera de la norma que cada sociedad establece. Porque con frecuencia erramos al entender el mundo desde una sola perspectiva, la nuestra, partimos del etnocentrismo de nuestra cultura, minusvalorando a las demás. 


\section{6.- ¡Qué guapa eres, Plu!}

\section{¡Qué guapa eres, Plu!}

Polly Dunbar

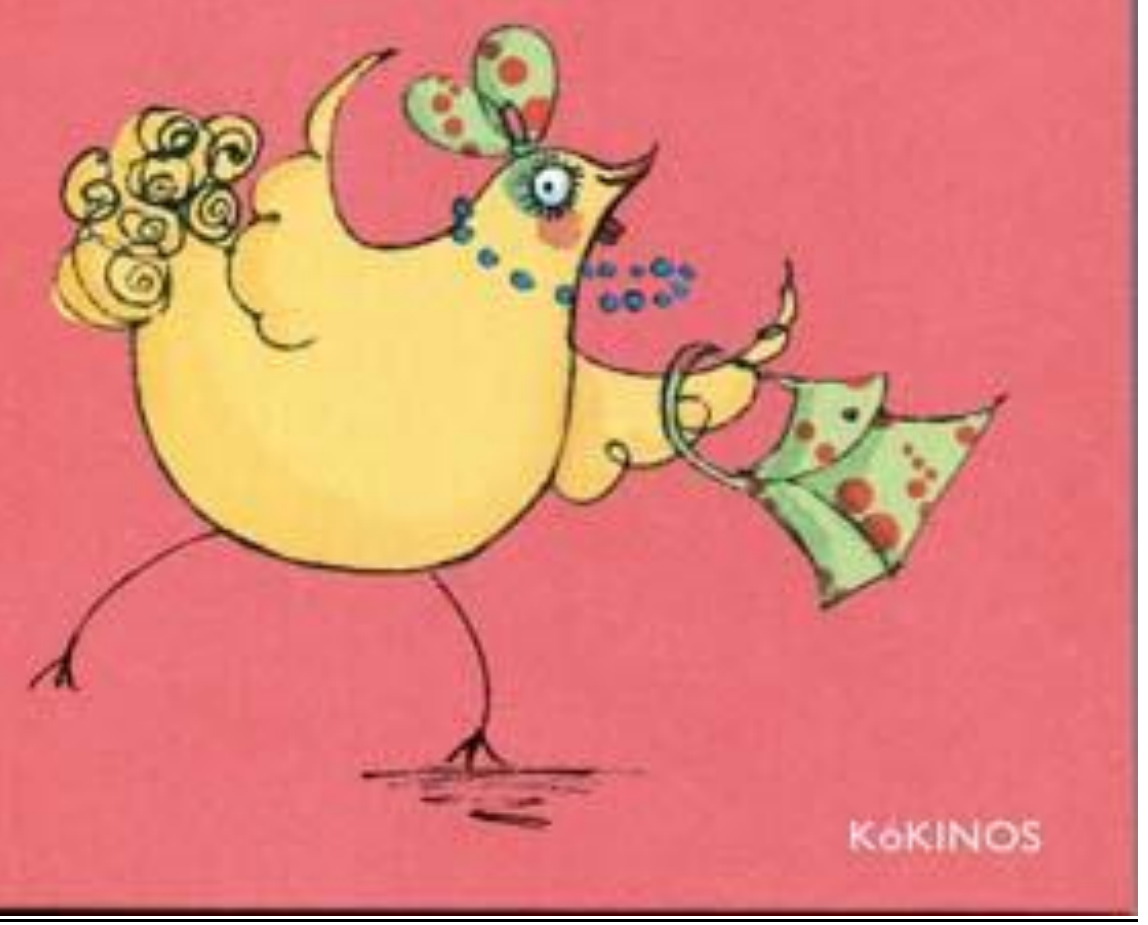

Dunbar, Polly. “iQué guapa eres, Plu!” Madrid: Kókinos, (2ª ed.) 2011. [1ª ed. 2009] 
- El siguiente libro, indicado para niños y niñas de cero a seis años, narra la historia de una gallina muy presumida llamada Plu, que se pasa el día maquillándose delante del espejo. Un día, su amigo elefante Patapam, le pregunta si puede usar su maquillaje para ponerse igual de guapo que ella, pero Plu se niega y dice con desaire que no, ya que según ella, él no sabe usarlo. En un descuido de Plu, el elefante le quita el bolso lleno de pinturas y reparte el maquillaje entre todos los demás amigos, para que puedan estar igual de guapos que ella. Cuando Plu se da cuenta de que ha perdido el bolso, pregunta uno a uno si lo han visto. Primero se acerca al cerdito que lleva las pestañas pintadas con rímel, pero él dice que no tiene el bolso, más tarde pregunta a un conejo que se ha maquillado coloretes rosas, y dice que tampoco sabe dónde está el bolso, y finalmente pregunta al lagarto que tiene las uñas pintadas de color rojo, pero este tampoco tiene el bolso, aunque señala a Patapam, el elefante, como el que ha tenido la magnífica idea de maquillarse y cuando lo observan éste va disfrazado como Plu, pintado y además lleva sus joyas. Finalmente se piden perdón entre todos y Plu regala el pintalabios al elefante y éste a su vez lo comparte con el resto de amigos para que todos puedan disfrutar maquillándose.

- Al igual que el resto de historias, se percibe una situación inicial en la que cada personaje realiza una acción, en este caso, Plu se maquilla delante del espejo, más tarde comienza el nudo de la historia en la que los personajes se van pintando con el maquillaje de Plu, y se da el conflicto cuando Plu no encuentra su bolso y comienza a preguntarse dónde está, finalmente se resuelve el conflicto ya que encuentra el bolso y se vuelve a una situación estable.

- En esta obra el narrador o narradora va relatando la historia pero da paso a los personajes para que ellos hablen cuando intervienen en la acción, por ejemplo, cuando la gallina pregunta al lagarto si ha visto su bolso le dice: ¡Dudú!, ¿Tú has visto 
mi bolso?, por tanto la autora emplea un discurso restituido o directo, dando más veracidad a la historia.

- Con respecto al análisis de discurso, la categoría de resolución de conflictos se percibe notoriamente a lo largo de la historia, ya que existe un conflicto entre Plu y sus compañeros, pero lo resuelven hablando pacíficamente y con respeto. La gallina habla con su amigo el elefante y deciden que ha sido una tontería y por ello no debe ser egoísta y compartir su maquillaje con los demás, por tanto aquí representa la importancia de la amistad y la generosidad con los demás, dando lugar a que todos se diviertan y sean felices.

Es llamativo que una acción como pintarse o maquillarse, algo propio del sexo femenino, quede representado en el cuento infantil como algo común en ambos sexos, ya que el personaje protagonista que es Plu, es una gallina, pero los demás animales aparecen representados como machos, y ellos mismos se pintan los ojos, los labios, las uñas, sin importar en absoluto el sexo de la persona, o en este caso, del animal, y queda muy claramente reflejado en el cuento, por tanto la categoría de igualdad de género y con ella los estereotipos asociados a cada sexo, son intercambiables en este relato infantil.

La obra muestra personajes tanto de animales como de niños, de hecho la gallina pide ayuda a su amiga Tilly para buscar el bolso, y ésta es una niña. La autora establece como valor emergente la naturalidad de que tanto niños y niñas como animales mantengan un lazo de afectividad, a la vez que representa el tema del maquillaje y la belleza a través de ambos sexos y aplicado a animales, hecho que da dinamismo y entretenimiento al lector, en este caso niños y niñas. Se percibe la amistad y la generosidad como el valor más importante a lo largo de todo el discurso. 
- Centrándome en el análisis de la imagen, se perciben unos dibujos muy llamativos y pintorescos, se muestran claramente los valores de la amistad y la felicidad a través de las imágenes, y el hecho más destacado es emplear la acción de maquillarse como un acto de diversión, y no sólo como algo que empleen las mujeres para embellecerse.

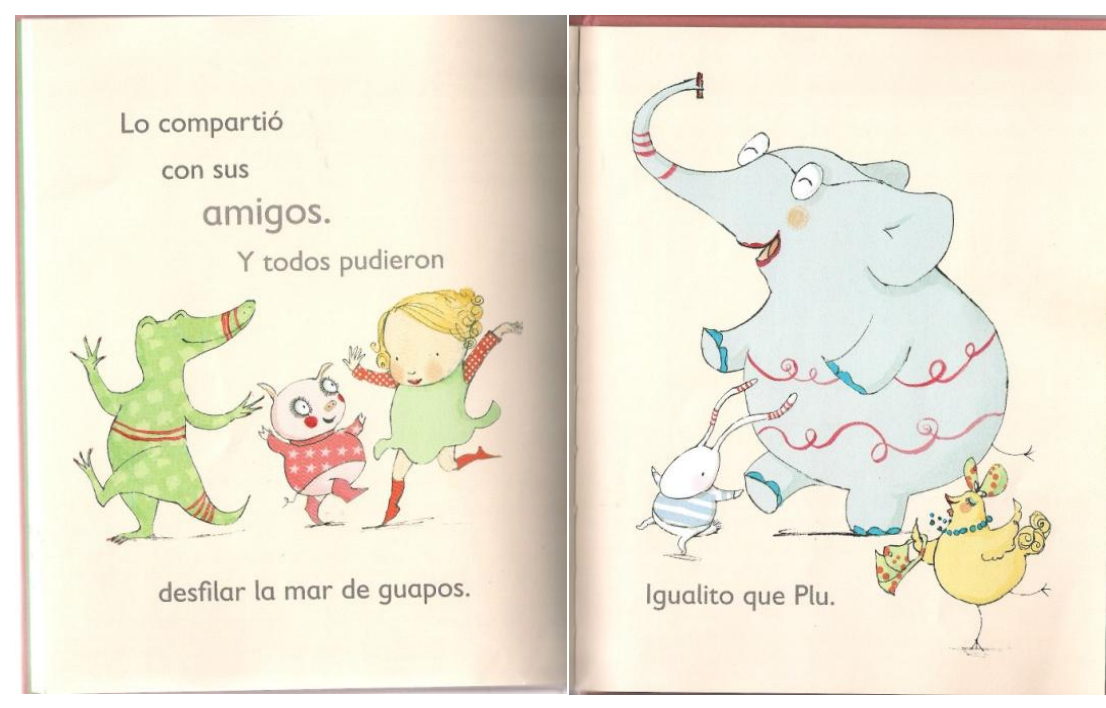

\section{Imagen 1}

Fuente: Dunbar, Polly. En ¡Qué guapa eres, Plu!, 2011, pp. 27-28

Todas las imágenes que aparecen en el cuento, reflejan el estado de ánimo que cada personaje va adquiriendo conforme aparecen nuevas situaciones, facilitando al lector o lectora sentir y comprender lo que del texto se deduce. Las imágenes se muestran de forma cómica, evocando una sensación de diversión y jocosidad y dando verosimilitud a la historia que se cuenta. 


\section{5.- CONCLUSIONES.}

El patriarcado es una orden social que se fundamenta en relaciones de poder sustentadas por la imposición de la supremacía masculina y consideración de lo femenino como inferior y subordinado, dando así origen a preceptos sociales que implican la imposición de órdenes por parte de los hombres y de las instituciones que les representan, sobre las mujeres. ${ }^{107}$ Estas reglas impuestas por el patriarcado en la sociedad, se ven reflejadas en todas las creaciones culturales y entre ellas, en la literatura, asignando unos principios determinados a los géneros femeninos y masculinos que aún a día de hoy siguen presentes en los imaginarios colectivos.

El lenguaje que se emplea, las animaciones que se visualizan y las historias que se cuentan, provocan en las personas más jóvenes una concepción del mundo y de la sociedad que en función de cómo se transmitan, puede difundir una idea u otra. El lenguaje modifica la historia, los papeles, las situaciones, podemos variar un acontecimiento en función del lenguaje que empleemos y éste suele ser sexista hacia las mujeres, porque las discrimina y las excluye de la historia, en definitiva las invisibiliza. La etapa de infantil es la fase educativa más sencilla y a la vez más compleja a la que tanto profesionales de la educación, como padres, madres o cualquier persona encargada de la educación de un o una menor se ven inmersos, ya que en su lenguaje, conocimiento y disposición está la clave para conseguir educar a un niño y a una niña al margen de cualquier estereotipo sexista y valores desiguales y potenciar así una educación basada en la igualdad de género y bajo propuestas coeducativas reales.

\footnotetext{
${ }^{107}$ Fernández, Rodolfo y Duarte, Andrea. “Preceptos de la ideología patriarcal asignados al género femenino y masculino, y su refractación en ocho cuentos utilizados en el tercer ciclo de la educación general básica del sistema educativo costarricense en el año 2005”, pp. 145
} 
Es el momento de trabajar aquellos elementos de discriminación sexista que falsean la coeducación y siguen atribuyendo estereotipos masculinos y femeninos moldeando a niños y niñas como seres dependientes y desiguales.

Como he comprobado a lo largo de mi investigación, son muchos los avances y las propuestas para erradicar y luchar contra la educación sexista que todavía se percibe en el currículo escolar, pasando desapercibida por su fuerte arraigo en las nociones tradicionales en las que se ha sustentado la educación a lo largo de las últimas décadas. Pero estos cambios en el modelo educativo y en la institución en general no son suficientes, porque como he cotejado, todavía no es un hecho visible que propuestas coeducativas se estén implantando en el aula y de manera transversal a todas las asignaturas, aún es necesario introducir asignaturas relacionadas con la coeducación dentro del currículum universitario, no sólo en magisterio infantil y revisar a fondo y seleccionar los materiales empleados dentro del aula, ya sea en la etapa de infantil, como en cualquier otra etapa del proceso educativo.

Como ha quedado reflejado, las leyes estatales y autonómicas se centran poco o casi nada en potenciar una igualdad de género en la etapa de educación infantil y lo mismo ocurre con el compromiso de introducir propuestas coeducativas al respecto, o la necesaria revisión del plan de estudios de titulaciones específicas que trabajen en la educación de niños y niñas. Todo estos temas conviene revisarlos y para ello es necesaria una concienciación global por parte de todos los sectores y profesionales encargados de la educación, para que perciban este problema social y todos y todas seamos partícipes de esto, para que se produzca el cambio, en el que la educación sea realmente coeducativa y potencie una verdadera igualdad de oportunidades tanto para hombres como para mujeres. 
A través de esta investigación, he querido dar a conocer la repercusión que puede llegar a tener la coeducación en niños y niñas de infantil, aplicada a una pequeña parte de los recursos empleados para educar, como son los cuentos infantiles. Si la coeducación llega a implantarse como una propuesta necesaria de manera transversal, los cambios pueden ser visibles y erradicaríamos así entre otros problemas, las desigualdades de género que conllevan a inferiorizar a las mujeres. El cambio es posible, pero para ello es necesario que todas las personas, incluyendo editoriales e institución, sean conscientes del problema de la reproduciendo de estereotipos sexistas a través de las prácticas educativas y para ello debemos dejar a un lado la utilización de los mismos mecanismos de enseñanza que seguimos empleando, como he podido comprobar y que reflejo en el capítulo de "Anexos", existen materiales didácticos alternativos a los tradicionales, que trabajan valores coeducativos basados en la igualdad de género, paz, tolerancia, generosidad, independencia, justicia, respeto, etcétera. Y no reproducen los estereotipos masculinos y femeninos desiguales asignados a cada sexo, impidiendo así una igualdad real de oportunidades entre hombres y mujeres. El problema es la difusión y el conocimiento sobre éstos en la población lectora, existen cuentos infantiles que trabajan todos estos aspectos y debe potenciarse su uso, tanto dentro como fuera de los centros educativos, para coeducar.

Haciendo un breve recorrido a lo largo de mi trabajo, puedo concluir que, apenas existen leyes que centren sus compromisos en una educación no sexista en la etapa de educación infantil, sólo hacen mención a una igualdad entre mujeres y hombres, pero en ningún momento trabajan la coeducación como principio obligatorio a cumplir dentro de los centros escolares, ni medidas y propuestas para trabajarla dentro del aula. Tampoco he percibido que el currículum universitario trabaje la coeducación de forma transversal, sólo en determinadas titulaciones, como las de magisterio infantil, abordan 
materias relacionadas con la coeducación, cuando considero que ésta debería ser una propuesta transversal aplicable a todas las titulaciones, abarcando compromisos coeducativos en los descriptores de las diferentes materias.

Centrándome en el análisis de cuentos infantiles no sexistas, puedo comprobar que realmente existen materiales que trabajan aspectos coeducativos en su contenido. Aspectos que abogan por una igualdad de género, que construyen un modelo de sujeto más libre e igualitario y que trabajan valores como; tolerancia, respeto, solidaridad, pacifismo, generosidad, etcétera. En algunos de ellos, se percibe cómo ciertos personajes se rebelan contra el sistema y cómo llegan a ser autosuficientes e independientes, a través de la lucha. También he podido comprobar cómo se invierten los roles que, históricamente han sido asociados a los hombres o a las mujeres, intentando a través de éstos, conseguir un modelo de persona más igualitario, reivindicando la posibilidad de que tanto mujeres como hombres compartan un mismo espacio, rompiendo la dicotomía: público-privado, racional-sentimental, débil-fuerte, etcétera. Aunque he podido comprobar cómo el lenguaje sigue siendo sexista, es decir, se continúa empleando el masculino genérico para designar tanto a colectivos de hombres como de mujeres, impidiendo esa visibilización por parte de las mujeres y enmascarándolas bajo sujetos pasivos y dependientes, siempre incluidas en la esfera masculina socialmente construida.

Considero que la coeducación implica todo esto y mucho más, debe quedar reflejado la diversidad en la que se basa nuestra sociedad en todas sus formas, ya sea variedad cultura, de familias, formas de vida, etcétera, al margen de cualquier tipo de discriminación. Todavía existen temas complejos para trabajar en la literatura infantil porque la sociedad es reticente a hablar de ellos, como por ejemplo las diferentes formas de construcción de una familia o la homosexualidad, considerando que por no ser 
"natural" y encontrarse fuera de lo "normal", no es lo correcto y se trata de esconderlo a la sociedad no hablando de ello y manteniéndolo en un segundo plano, por ello es necesario esa concienciación y visibilización a los niños y niñas a través de los cuentos infantiles, de una manera fácil de comprender para así construir sujetos libres de prejuicios e iguales. Nuestra sociedad es un reflejo de estos cuentos ya que estos textos delimitan los papeles y relaciones que se establecen en una determinada cultura, por ello es tan importante la deconstrucción de los estereotipos sexistas que aparecen en la literatura infantil, porque en cierto sentido, es la deconstrucción de nuestra sociedad patriarcal y restrictiva.

Para finalizar estas conclusiones, quisiera manifestar que existen otras posibilidades para encontrar y disfrutar de literatura infantil alternativa a la tradicional, donde niños, niñas, adultos y adultas puedan disfrutar de cada historia y enriquecerse de otros modelos de personas y formas de vida fuera de prejuicios y de roles discriminatorios en función del sexo, el problema es la difusión de éstos y la demanda que la sociedad tiene sobre ellos, puesto que no se dan a conocer con la misma intensidad que los cuentos infantiles tradicionales porque no se potencia su lectura y su uso, tanto es así, que la sociedad en general no tiene conocimiento de la existencia de esta literatura alternativa que invierta las tradiciones y deconstruya los roles estereotipados, de hecho la mayoría no llega ni a plantearse el problema que albergan los cuentos infantiles como transmisores de valores discriminatorios y sexistas y lo que esto conlleva en la educación de niños y niñas a lo largo de su proceso de socialización y aprendizaje. 


\section{* 4.1 PROPUESTAS PARA UNA FUTURA INVESTIGACIÓN.}

Una manera de profundizar en este estudio, sería ampliar el análisis sobre la coeducación como propuesta pedagógica para denunciar el sexismo dentro del sistema educativo y más concretamente, en la organización y disposición de las aulas. Para llevar a cabo esta investigación, no sólo habría que realizar una revisión bibliográfica de una parte de los documentos y materiales empleados en esta, sino centrar mi investigación en los comportamientos y actitudes que el profesorado mantiene en el aula con respecto al alumnado, para comprobar el lenguaje, los mecanismos de enseñanza y los discursos que éstos emplean.

La idea sería ampliar este análisis a otras etapas educativas, no sólo en educación infantil, para comprobar cómo niños y niñas se relacionan dentro del aula con sus compañeros y compañeras y el vínculo que éstos mantienen con el profesorado, a la vez que, estudiar los comportamientos que manifiestan tanto unos como otros, en relación a los acontecimientos que van sucediendo. Sería importante analizar todo lo referente al currículum oculto de los centros escolares y cómo los aspectos relacionados con temas de género, son representados y se trabajan dentro del aula.

Para elaborar la parte empírica, sería conveniente realizar entrevistas y cuestionarios tanto a docentes como alumnos y alumnas, para comprobar cómo la coeducación, como propuesta pedagógica para erradicar resquicios de sexismo, se percibe y se trabaja desde dentro del aula. El propósito sería comprobar si la coeducación se ejerce de forma transversal, o si por el contrario, se trabaja de manera abstracta, tan sólo en ciertos aspectos y situaciones específicas. La metodología a utilizar sería la observación participante, para comprobar cómo transcurre el día a día 
del alumnado y profesorado y diversos cuestionarios y entrevistas, a todas las personas que participen en el día a día del proceso de aprendizaje de los niños y niñas.

La cuestión es evaluar el impacto que la coeducación está teniendo actualmente en los centros escolares, que mantienen un compromiso con una educación igualitaria, para comprobar de primera mano, si existe o no un compromiso coeducativo en la dinámica y funcionamiento del aula que, tanto profesores como profesoras, emplean diariamente para educar. Para ello habría que elaborar un plan de antemano, para fijar los objetivos que pretendo alcanzar y qué aspectos quiero trabajar, a su vez que, determinar cómo van a desarrollarse las entrevistas y cuestionarios y qué pretendo alcanzar y conseguir a través de éstos. 


\section{4.- ANEXOS.}

REVISTAS, EDITORIALES Y COLECCIONES DE LIBROS COEDUCATIVOS EN LA RED

En los últimos años, Internet ha pasado de ser una herramienta eficaz en la difusión de novedades y títulos del fondo editorial, a extender su utilidad a la hora de fomentar la lectura e intercambiar información e impresiones sobre literatura, especialmente entre los jóvenes. Una herramienta de la que paulatinamente van haciendo uso tantos profesionales (editores, libreros, escritores, ilustradores, traductores, bibliotecarios), como instituciones y lectores. Entre estos últimos, el joven lector y lectora es precisamente el más social a la hora de leer encontrando en Internet un espacio de comunicación atractivo en el que compartir con autores o con otros lectores, sus impresiones en torno a determinados títulos, géneros, autores y otros temas relacionados con el libro y la lectura ${ }^{108}$. A día de hoy no es necesario tener un cuento infantil en formato papel para educar y ser educados sino que a través de Internet es posible disponer de cualquier material didáctico en versión digital.

Existen diversas páginas webs infantiles y juveniles que nos proporcionan información sobre cualquier cuento infantil a través de la red como:

- $\quad$ www.sol-e.com (Servicio de Orientación de Lectura) Esta página ha sido la utilizada para obtener los cuentos infantiles coeducativos que he seleccionado anteriormente, en ella cualquier persona puede consultar el libro infantil o juvenil que desee en función de la edad, dispone de libros para niños y niñas de entre 0 a 18 años. Este servicio ofrece la posibilidad de buscar un libro dentro de

\footnotetext{
108 Ministerio de cultura. Servicio de Estudios y Documentación. Los libros infantiles y juveniles, 2010, p. 21
} 
cada periodo de edad en función de una materia determinada, ya sea; feminismo, igualdad, mujer, sexismo, etcétera, lo que facilita la opción de encontrar un libro que se ajuste a los deseos del y la internauta. Consiste en una alternativa a los métodos tradicionales de buscar literatura en una librería convencional, que se pueda ajustar a las preferencias del lector, ya que en estas no suelen estar todos los cuentos existentes, sino los más vendidos y demandados impidiendo que cualquier cliente pueda acceder y conocer otros materiales didácticos alternativos, al margen de los tradicionales. Gracias a estos recursos es posible hacer una búsqueda más específica y directa de los libros que estamos buscando en función de una materia determinada, a la vez que facilita la opción de encontrar un libro que se ajuste a determinadas preferencias desde cualquier punto con conexión a internet.

- $\quad$ www.clubkirico.com Consiste en una página de libreros y libreras por Internet que hace una búsqueda específica de los cuentos que existen en el mercado en función de una determinada materia. Al igual que la anterior página web, ésta también facilita la selección y elección de libros coeducativos dentro de un enorme listado de literatura infantil a la vez que sugieren cuales son los más vendidos y demandados por los clientes.

- $\quad$ www.fundaciongsr.com El Centro Internacional del Libro Infantil y Juvenil de la Fundación Germán Sánchez Ruipérez (CILIJ) trabaja en la literatura infantil y juvenil para apoyar y promover la lectura en este género. La fundación pretende adentrar a los y las menores en la LIJ $^{109}$ desde edades muy tempranas y ser

${ }^{109}$ LIJ:Literatura Infantil y Juvenil 
capaces de disfrutar y aprender con ella centrando la mayor parte de sus programas en la difusión y extensión de la cultura del libro y la lectura. También consta de una amplia literatura recomendada a las preferencias del lector, al mismo tiempo que tienen en marcha varios proyectos para fomentar la lectura y hacer que ellas y ellos participen activamente en sus proyectos.

También podemos encontrar revistas de literatura a través de la web como por ejemplo;

- $\quad$ www.revistababar.com Es una revista que nació en 1989 en el colegio Federico García Lorca de Arganda del Rey. Lo que comenzó siendo una actividad extraescolar acabó convirtiéndose en un portal especializado en literatura infantil y juvenil. Facilita la opción de conocer los números impresos de Babar a través del portal de literatura infantil que la Biblioteca Virtual Cervantes ha digitalizado, consiguiendo que los y las internautas puedan acceder de manera rápida y útil a la búsqueda de materiales coeducativos existentes a día de hoy.

También he encontrado algunas editoriales conocidas que han publicado colecciones de libros coeducativos, entre ellas podemos destacar:

A favor de las niñas. Es una colección de cuentos creada por Adela Turín junto a Nela Bosnia, esta colección no se encuentra en internet pero es fácil encontrarla a través de la editorial “Lumen”. Los libros que la componen toman de base unos modelos de situaciones alternativos a favor de las niñas, se invierten los roles establecidos para las mujeres de los cuentos infantiles tradicionales. Esta colección de libros ha sido traducida a varios idiomas y vendida en cantidad de países, a día de hoy sólo esta editorial la promociona en España aunque ha modificado el texto original de algunos de los cuentos, por considerar que es de 
difícil comprensión para los niños y las niñas de esas edades. Entre sus cuentos más conocidos se encuentran; Arturo y Clementina, Historia de los bonobos con gafas, Rosa Caramelo, Las hierbas mágicas, etcétera, todo ellos son cuentos coeducativos porque se alejan de la línea sexista dominante de la cultura del libro tradicional que impone desigualdades hacia la mujer y emplea una educación más igualitaria donde las personas adultas se liberan de sus propios prejuicios.

\section{Cuentos infantiles políticamente correctos y Más cuentos infantiles} políticamente correctos cuyo autor es: James Finn Garner. "Circe” es la editorial que se ha encargado de publicarlos. Estos dos materiales versionan los cuentos tradicionales a los que estamos acostumbrados a leer y escuchar, la Cenicienta, Blancanieves, Caperucita roja, y muchos más. Fueron escritos entre los años 1995 y 1996, el autor escogió todos los cuentos típicos de la literatura infantil para hacer una crítica a su escritura sexista, y los modelos de mujer que existen bajo la mirada patriarcal. En palabras del autor, estos libros pretenden liberar los antiguos cuentos de hadas con los que todos crecimos de sus actitudes sexistas, racistas, nacionalistas, regionalistas, intelectualistas, socioeconomistas, etnocéntricas, falocéntricas, heteropatriarcales o discriminatorias. El autor escoge cada cuento considerado de la literatura infantil y modifica el comportamiento de los personajes a la vez que explica por qué ese comportamiento debe ser cambiado bajo una sociedad coeducativa, libre e igualitaria. Emplea un lenguaje apto para todas las personas aunque con frecuencia utiliza palabras complejas para el público más pequeño. Considero que estas dos obras presentan valores coeducativos porque además de revisar todos los contenidos sexistas que aparecen en las obras literarias tradicionales también los modifica por aspectos que reflejen la igualdad de género, la resolución de conflictos por la vía pacífica, etcétera, es un buen material para las 
personas adultas a modo de concienciación para que perciban el daño que puede ocasionar la reproducción de los mismos roles discriminatorios y sexistas hacia la mujer en un colectivo tan manejable como son los niños y niñas de infantil y muestra la posibilidad de modificar las obras conocidas en todo el mundo, para reescribirlas ajenas a modelos de conductas discriminatorios.

Son más las colecciones y páginas webs disponibles en la red a través de las cuales podemos encontrar y disponer de buena literatura infantil al margen de materiales sexistas y discriminatorios, aunque destaco estas por la función e influencia que han tenido a lo largo de mi proyecto de investigación. He utilizado algunas colecciones de libros y servicios de biblioteca a través de la red para argumentar y construir mi discurso coeducativo que he reflejado en estas líneas donde poder demostrar la generación de literatura coeducativa que existe y podemos encontrar en el mercado aunque no sea tan conocida ni difundida como los materiales didácticos tradicionales que aún se mantienen en la población de infantil.

Por último muestro el listado de editoriales que la Junta de Andalucía recomienda utilizar al lector, a los centros educativos y a los y las profesionales encargados de la educación, para disponer de cuentos infantiles y juveniles: 


\begin{tabular}{|c|c|}
\hline GRUPO EDITORIAL & DIRECCIÓN WEB \\
\hline Alianza & www.alianzaeditorial.es \\
\hline Anaya & www.anayainfantilyjuvenil.es \\
\hline B, Ediciones B & www.edicionesb.com \\
\hline Bárbara Fiore & www.barbara-fiore.com \\
\hline Brosquil & www.brosquilediciones.com \\
\hline Bruño (grupo Anaya) & www.editorial-bruno.es \\
\hline Combel & www.editorialcasals.com \\
\hline Corimbo & www.corimbo.es \\
\hline Destino Infantil y juvenil & www.destinojoven.com \\
\hline Edebé & www.edebe.com \\
\hline Edelvives & www.edelvives.com \\
\hline Edimat libros & www.edimat.es \\
\hline Everest & www.everest.es \\
\hline Factoría K de Libros & www.faktoriakdelibros.com \\
\hline $\begin{array}{l}\text { Fondo Cultura económica } \\
\text { España }\end{array}$ & www.fcede.es \\
\hline Juventud & www.editorialjuventud.es \\
\hline $\begin{array}{c}\text { Kalandraka Ediciones } \\
\text { Andalucía }\end{array}$ & www.kalandraka.com \\
\hline Kókinos & www.editorialkokinos.com \\
\hline La Galera & www.lagalera.cat \\
\hline Libro Hobby Club & www.librohobby.com \\
\hline Libsa & www.libsa.es \\
\hline Lóguez & www.loguezediciones.com \\
\hline Media vaca & www.mediavaca.com \\
\hline Miguel A. Salvatella & www.salvatella.com \\
\hline Nova Galicia & www.novagalicia.com \\
\hline Océano & www.oceano.com \\
\hline OQO & www.oqo.es \\
\hline Parramón & www.parramon.com \\
\hline Pearson educación & www.pearsoneducacion.com \\
\hline Random House Mondadori & www.randonhousemondadori.es \\
\hline Salamandra & www.salamandra.info \\
\hline Santillana-Alfaguara & www.alfaguara.santillana.es \\
\hline Sirpus & www.sirpus.com \\
\hline Siruela & www.siruela.com \\
\hline Ediciones SM & www.grupo-sm.com/inicio.asp \\
\hline Susaeta & www.susaeta.com \\
\hline Timun Mas & www.timunmas.com \\
\hline Versos y Trazos & www.versosytrazos.com \\
\hline Vicens vives & www.vicensvives.es \\
\hline
\end{tabular}




\section{5.- REFERENCIAS Y FUENTES BIBLIOGRÁFICAS.}

- Aparici, Roberto, García, Agustín y Valdivia, Manuel. La imagen. Madrid: Universidad nacional de educación a distancia (UNED), 1992

- Browne, Naima y France, Pauline. Hacia una educación infantil no sexista. Madrid: Ed. Morata, 1988

- Birkhauser-Oeri, Sybylle. La llave del oro. Madres y madrastras en los cuentos infantiles. Madrid: Turner Publicaciones S.L., 2010. pp. 13-18

- Capdevila, Roser y Capdevila, Carles. Las tres mellizas hacen las paces. Madrid: Icaria editorial, 2001

- Cerrillo, Pedro C. Cañamares, Cristina y Sánchez, César. Literatura infantil; nuevas lecturas, nuevos lectores. Ediciones de la universidad de Castilla-La Mancha, 2007

- Cerrillo, Pedro C. Literatura Infantil y Juvenil y educación literaria. Hacia una nueva enseñanza de la literatura. Barcelona: Ed. Octaedro, S.L., 2007

- Colomer, Teresa. Introducción a la literatura infantil y juvenil. Madrid: Ed. Síntesis, S.A., 1999

- Dane, Marion y Butler, John. Una mama para Owen. Barcelona: RBA Libros, S.A., 2007

- Díaz, Raquel: ¿Hay algo más aburrido que ser una princesa rosa? Barcelona: Thule Ediciones, S.L., 2012

- Dunbar, Polly. ¡Qué guapa eres, Plu! Madrid: Kókinos, 2011

- Finn, James. Cuentos infantiles políticamente correctos. Barcelona: Circe Ediciones, S. A., 1995

- Finn, James. Más cuentos infantiles políticamente correctos. Barcelona: Circe Ediciones, S.A., 1996

- Guinea, Juan y Cordero, M $\mathrm{M}^{\mathrm{a}}$ José. Una fiesta sin igual. Bilbao: A Fortiori Editorial., 2011

- Lomas, Carlos, et, al. ¿Iguales o diferentes? Género, diferencia sexual, lenguaje y educación. Barcelona: Paidós Educador., 1999 
- Lluch, Gemma. Análisis de narrativas infantiles y juveniles. Ediciones de la universidad de Castilla-La Mancha, 2003

- Lluch, Gemma. Invención de una tradición literaria (De la narrativa oral a la literatura para niños). Ediciones de la universidad de Castilla-La Mancha, 2007

- Marzal, Javier. Cómo se lee una fotografía. Interpretaciones de la mirada. Madrid: Ed. Cátedra, 2010

- Mata, Juan. "La noción del placer está indefectiblemente unida a la lectura". En 10 ideas clave. Animación a la lectura. Hacer de la lectura una práctica feliz, transcendente y deseable. Barcelona: Editorial GRAÓ, 2008, pp.45

- Nobile, Angela. Literatura infantil y juvenil. La infancia y sus libros en la civilización tecnológica. Madrid: Ed. Morata, S.A., 1992

- Robles, Victoria. "Cuando los cambios son también nuestros: movimientos feministas y propuestas educativas transformadoras". En Añaños, Fanny (coord...). Las mujeres en las prisiones. La Educación Social en contextos de riesgo y conflictos. Barcelona, Gedisa, 2010, pp 137-154

- Robles, Victoria. "Educadoras en la conformación de una nueva ciudadanía: feminismo y propuestas educativas transformadoras". En Robles, Victoria. Educadoras en tiempo de transición. Madrid, Morata, en prensa

- Simón, Ma Elena. Hijas de la igualdad, herederas de injusticias. Madrid: Narcea, S.A., 2008

- Simón, $\mathrm{M}^{\mathrm{a}}$ Elena. La igualdad también se aprende, Cuestión de coeducación. Madrid: Narcea, S.A., 2010

- Solinís, Tessie y Barba, Alejandra. Inés tres pies. México: CIDCLI, S.C., 2004

- Subirats, Marina y Brullet, Cristina. La coeducación. Plan para la igualdad de oportunidades para las mujeres. Madrid: Ministerio de educación y ciencia, Secretaría de Estado de Educación, 1991, pp. 43

- Tomé, Amparo y Rambla, Xavier. Contra el sexismo. Coeducación y democracia en la escuela. Madrid: Editorial Síntesis, S.L., 2001

- Turín, Adela. Los cuentos siguen contando. Algunas reflexiones sobre los estereotipos. Madrid: horas y HORAS, 1995 
- Urruzola, $\mathrm{M}^{\mathrm{o}}$ José. ¿Es posible coeducar en la actual escuela mixta? Una programación curricular de aula sobre las relaciones afectivas y sexuales. Bilbao: Maite Canal, 1991

- Van, Teun. Análisis crítico del discurso. En: Wodak, Ruth y Meyer, Michael, Métodos de análisis crítico del discurso. Barcelona: Ed. Gedisa, S.A., 2003

- Vega, Ana, et al. Mujer y educación. Una perspectiva de género. Málaga: Ediciones Aljibe, S.L., 2007

Leyes, Guías, Órdenes y Planes:

- Ley Orgánica No 313, 1/2004, de 28 de diciembre, de Medidas de Protección Integral contra la Violencia de Género, Boletín Oficial del Estado, Madrid, España, 29 de diciembre de 2004

- Ley Orgánica No 106, 2/2006, de 3 de mayo, de Educación. Boletín Oficial del Estado, Madrid, España, 4 de mayo de 2006

- Guía de Coeducación. Documento de Síntesis sobre la Educación para la Igualdad de Oportunidades entre Mujeres y Hombres. Ministerio de trabajo y asuntos sociales. Secretaria General de Políticas de Igualdad, Madrid, España, Noviembre, 2007

- Ley Orgánica № 89, 4/2007, de 12 de abril, por la que se modifica la Ley Orgánica 6/2001, Madrid, España, de 21 de diciembre, de Universidades, Boletín Oficial del Estado, 13 abril de 2007

- Ley N²52, 17/2007, de 10 de diciembre, de Educación de Andalucía, Boletín Oficial de la Junta de Andalucía, Sevilla, España, 26 diciembre de 2007

- Ley N N $^{\mathrm{O}} 247,12 / 2007$, de 26 de noviembre, para la promoción de la igualdad de género en Andalucía, Boletín Oficial de la Junta de Andalucía, Sevilla, España, 18 de diciembre de 2007

- Orden $\mathrm{N}^{\circ} 29$ de 15 de mayo de 2006, por la que se regulan y desarrollan las actuaciones y medidas establecidas en el I Plan de Igualdad entre Hombres y Mujeres en Educación, Boletín Oficial de la Junta de Andalucía, Sevilla, España, 25 de mayo de 2006

- Plan Estratégico de Igualdad de Oportunidades (2008-2011), Ministerio de trabajo y asuntos sociales. Secretaria General de Políticas de Igualdad, Madrid, España, Diciembre 2007 
- I Plan de Igualdad entre hombres y mujeres en educación. Junta de Andalucía, Consejería de Educación, Sevilla, España, 2 de Noviembre de 2005

- I Plan estratégico para la igualdad de mujeres y hombres en Andalucía 20102013. Junta de Andalucía. Consejería para la Igualdad y Bienestar Social, Sevilla, España, Enero 2010

Páginas Webs consultadas:

- Babar. Revista infantil y juvenil [en línea] [Fecha de consulta 2 de agosto 2012]: http://bib.cervantesvirtual.com/hemeroteca/babar/catalogo.shtml

- Gobierno de España. Ministerio de empleo y seguridad social. Disponible en web [en línea] [Fecha de consulta 30 de mayo 2012]: http://www.empleo.gob.es/es/igualdad/index.htm

- Gobierno de España. Ministerio de educación, cultura y deporte. Disponible en web [en línea] [Fecha de consulta 5 de junio 2012]: http://www.educacion.gob.es/educacion/sistema-educativo/educacion-genero.html

- Gobierno de España. Ministerio de educación, cultura y deporte. Universidades Españolas. Disponible en web [en línea] [Fecha de consulta 8 de Mayo 2012]: http://www.educacion.gob.es/educacion/universidades/educacion-superioruniversitaria/que-estudiar-donde/universidades-espanolas.html

- Gobierno de España. Ministerio de sanidad, servicios sociales e igualdad. Disponible en web [en línea] [Fecha de consulta 5 de junio 2012]: http://www.msssi.gob.es/ssi/portada/home.htm

- Gobierno de España. Conserjería de Educación. Portal Libro Abierto. Disponible en web [en línea] [Fecha de consulta 2 de agosto 2012]: http://www.juntadeandalucia.es/educacion/webportal/web/portal-libroabierto/resenas/libros-infantiles-y-juveniles/-/noticia/detalle/clasicos-escolares-i

- Junta de Andalucía. Instituto de la Mujer. Consejería de la Presidencia e Igualdad. Disponible en web [en línea] [Fecha de consulta 29 de mayo 2012]: http://www.juntadeandalucia.es/institutodelamujer/index.php/coeducacion

- Servicio de Orientación a la Lectura. Disponible en web [en línea] [Fecha de consulta 2 de agosto 2012]: http://www.sol-e.com/ 